THIAGO HABACUQUE SILVA DE SOUZA

ASPECTOS ESTRUTURAIS, ULTRAESTRUTURAIS E QUANTITATIVOS DOS EFEITOS DA DESNUTRIÇÃO PROTÉICA PRÉ E PÓS-NATAL E DA RENUTRIÇÃO PÓS-NATAL NO PLEXO GANGLIONAR DA TRAQUÉIA DE RATOS

\footnotetext{
Dissertação apresentada ao Programa de Pós-Graduação em Ciências Morfofuncionais do Instituto de Ciências Biomédicas da Universidade de São Paulo, para obtenção do Título de Mestre em Ciências.
} 


\title{
ASPECTOS ESTRUTURAIS, ULTRAESTRUTURAIS E QUANTITATIVOS DOS EFEITOS DA DESNUTRIÇÃO PROTÉICA PRÉ E PÓS-NATAL E DA RENUTRIÇÃO PÓS-NATAL NO PLEXO GANGLIONAR DA TRAQUÉIA DE RATOS
}

\author{
Dissertação apresentada ao Programa \\ de Pós-Graduação em Ciências \\ Morfofuncionais do Instituto de Ciências \\ Biomédicas da Universidade de São \\ Paulo, para obtenção do Título de \\ Mestre em Ciência. \\ Área de concentração: \\ Ciências Morfofuncionais \\ Orientador: \\ Prof. Dr. Edson Aparecido Liberti
}


DADOS DE CATALOGAÇÃO NA PUBLICAÇÃO (CIP)

Serviço de Biblioteca e Informação Biomédica do

Instituto de Ciências Biomédicas da Universidade de São Paulo

(c) reprodução total

Habacuque, Thiago Silva de Souza.

Aspectos estruturais, ultraestruturais e quantitativos dos efeitos da desnutrição protéica pré e pós-natal e da renutrição pós-natal no plexo ganglionar da traquéia de ratos / Thiago Silva de Souza Habacuque. - São Paulo, 2010.

Orientador: Edson Aparecido Liberti.

Dissertação (Mestrado) - Universidade de São Paulo. Instituto de Ciências Biomédicas. Departamento de Anatomia. Área de concentração: Ciências Morfofuncionais. Linha de pesquisa: Estudo dos plexos autonômicos

Versão do título para o inglês: Structural, ultraestructural and quantitative aspects from pre and postnatal protein deprivation and postnatal refeeding effects on ganglioned trachea plexus of the rats.

Descritores: 1. Traqueia 2. Desnutrição 3 . Morfometria 4. Renutrição 5.Ultraestrutura 6. I. Liberti, Edson Aparecido II. Universidade de São Paulo. Instituto de Ciências Biomédicas. Programa de Pós-Graduação em Anatomia III. Título. 
Candidato(a):

Título da Dissertação:

Orientador(a):
Thiago Habacuque Silva de Souza.

Aspectos estruturais, ultraestruturais e quantitativos dos efeitos da desnutrição protéica pré e pós-natal e da renutrição pós-natal no plexo ganglionar da traquéia de ratos.

A Comissão Julgadora dos trabalhos de Defesa da Dissertação de Mestrado, em sessão pública realizada a ..$/ \ldots$
( ) Aprovado(a)
( ) Reprovado(a)

Examinador(a): Assinatura:

Nome:

Instituição:

Examinador(a): Assinatura:

Nome:

Instituição:

Presidente: Assinatura:

Nome:

Instituição: 


\section{Certificado}

Certificamos que o protocolo registrado sob $\mathrm{n}^{\circ} \mathbf{0 6 9}$ nas fls. $\mathbf{5 8}$ do livro 02 para uso de animais em experimentação, sob a responsabilidade de Edson Aparecido Liberti, Coordenador(a) da Linha de pesquisa "Aspectos estruturais, ultraestruturais e quantitativos dos efeitos da desnutrição protéica pré e pós-natal e da renutrição pós-natal no plexo ganglionar da traquéia de ratos" do qual participou(aram) o(s) alunos Thiago Habacuque Silva de Souza, está de acordo com os Princípios Éticos de Experimentação Animal adotado pelo Colégio Brasileiro de Experimentação Animal (COBEA) e foi aprovado pela COMISSÃO DE ÉTICA EM EXPERIMENTAÇÃO ANIMAL (CEEA) em 19.11.08, com validade de 3 anos.

São Paulo, 24 de novembro de 2008.

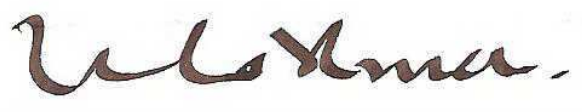

Prof. Dr. WOTHAN TAVARES DE LIMA Coordenador CEEA - ICB/USP

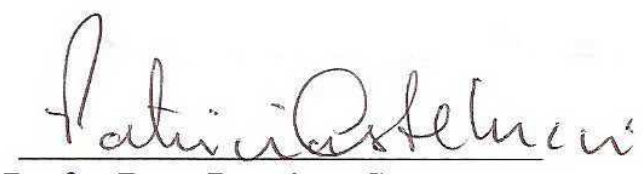

Profa. Dra. PATRICIA CASTELUCCI

Secretária CEEA - ICB/USP 
Dedico

\author{
Aos meus pais \\ Tarcísio José de Souza \\ Rosana Silva de Souza
}

Aos meus avôs

José Dertrudes de Souza

Rosinha Zaneti de Souza

Rosalvo Ernestino da Silva

Veraldina Maria da Silva

Aos meus bisavôs

Odorico Silvino Guimarães

Ana Bernadina da Silva

Henrique Zaneti

Angelina Marchiori Zaneti

Ernestino Manoel da Silva

Ermenegilda Joaquina de Jesus

Joaquim Manoel dos Santos

Joventina Maria de Jesus

"O homem que não conhece a sua própria história,

Não conhece a si mesmo."

Autor desconhecido 


\section{AGRADECIMENTOS}

À Deus por permitir a travessia dos obstáculos desta caminhada, com muita saúde e determinação, sempre com o auxílio de excelentes pessoas ao meu redor.

À minha querida família, Rosana Silva de Souza, Tarcísio José de Souza, Victor Habacuque Silva de Souza, Veraldina Maria da Silva, Rosimeire Guedes Ferreira da Silva, Rosi da Silva, Alberto Muffalo Rabassa Júnior e Felipe Muffalo Rabassa, obrigado pela educação, amor, carinho e segurança durante toda a minha vida. Amo vocês.

Aos inestimáveis amigos Roberto Portilho da Silva Júnior, Mariana Santos Silva, Suelen Bianchi da Silva, Núria Szönyi Gerardi, Gustavo Ferreira Barcelos, João Barbosa Neto, Gabriela Kato de Oliveira Barbosa, Talita Ponciano Carneiro, Flávia Regina Ortiz Serra Vendramini, Fábio Titonelli e Vinícius Cestari do Amaral, exemplos de força, determinação, simplicidade, dedicação e humildade.

À minha amada namorada Sâmia Geórgia Dantas Linhares, por sempre acreditar e me dar o apoio necessário para a realização dos meus sonhos, pelo amor, dedicação, cuidados, paciência, compreensão e o apoio incondicional de todos os dias. 
Ao professor Dr. Edson Aparecido Liberti, pelos ensinamentos, não os profissionais, que em decorrência do convívio quase que diário eu também aprendi muito, mas sim por aqueles ensinamentos da vida, da nossa existência e para o convívio com o nosso próximo por toda a vida. Exemplo de homem e profissional digno. É enorme a satisfação em vê-lo se dedicando ao magistério da vida, sempre oferecendo a sua máxima contribuição para a formação de todos, desde colegas de trabalho até o seu mais novo aluno.

À professora Silvia de Campos Boldrini, que com muita vontade e disposição faz com que o convívio no laboratório seja o melhor possível, muitas vezes sacrificando os seus projetos para ouvir os sonhos dos outros.

À quatro grandes mulheres, as quais eu devo muito:

Professora Flávia de Oliveira, a senhora talvez mesmo sem saber, sempre me estendeu a mão, sempre me ouviu, sempre me ajudou no que pode, sempre me orientou e sempre estava próxima quando eu precisei de um conselho. Obrigado por ter feito com que eu não desistisse da carreira acadêmica e mais ainda, por ter me trazido até as mãos do professor Edson.

Sra. Patrícia Rodrigues de Campos Rocha, para falar a verdade não faço ideia de quantas, e quantas vezes você me ajudou, desde os primeiros dias, quando eu ainda nem era aluno matriculado da pós-graduação. Sempre simpática, educada e solicita, serei eternamente grato! 
Sra. Renaide Rodrigues Ferreira Gacek, que me ensinou muito sobre o acasalamento dos animais, pela prontidão sempre imediata e por sempre ter me ajudado a conseguir os animais utilizados nesta pesquisa.

Sra. Rosana Duarte Prisco, que com impressionante destreza domina a informação estatística sem hesitar. Foram horas a fio de discussões e ensinamentos "numéricos" que guardarei com bastante prazer na minha memória.

À instituição e aos professores da Faculdade do Clube Náutico Mogiano pela contribuição que cada um ofereceu para a minha formação como Fisioterapeuta.

Aos supervisores e colegas fisioterapeutas que auxiliaram na minha formação como especialista pela Santa Casa de Misericórdia de São Paulo e pelo Hospital das Clínicas da Faculdade de Medicina da Universidade de São Paulo.

Ao colega Ricardo Bragança de Vasconcelos Fontes, que entre todas as suas ocupações, me auxiliou na compreensão e embasamento de assuntos fundamentais para o momento do exame de seleção para entrada no Programa de Pós-Graduação em Ciências Morfofuncionais do Instituto de Ciências Biomédicas da Universidade de São Paulo. Obrigado Mestre!

Ao Prof. Dr. José Cipolla Neto por estar presente na banca de exame de seleção para a entrada no Programa de Pós-Graduação em Ciências 
Morfofuncionais do Instituto de Ciências Biomédicas da Universidade de São Paulo.

Ao Programa de Pós-Graduação em Ciências Morfofuncionais do Instituto de Ciências Biomédicas da Universidade de São Paulo.

Aos professores que formaram a Banca de qualificação, Dra. Flávia de Oliveira, Dra. Laura Beatriz Mesiano Maifrino e Dr. Odair Alfredo Gomes pelas significantes considerações para o desenvolvimento e adequação do trabalho.

Aos professores Dr. Edson Aparecido Liberti e Dr. Luís Ronaldo Picosse, responsáveis pela Disciplina de Anatomia para o curso de Odontologia da Universidade de São Paulo pela permissão da realização de Monitoria e posterior participação do Programa de Aperfeiçoamento de Ensino respectivamente para as turmas de 2008 e 2009.

Aos professores Dr. Cesar Alexandre Fabrega Carvalho, Dra. Cecília Helena Azevedo Gouveia Ferreira e Dr. Esem Pereira Cerqueira, responsáveis pela Disciplina de Anatomia do Aparelho Locomotor para o curso de Medicina da Universidade de São Paulo pela permissão da participação do Programa de Aperfeiçoamento de Ensino para a turma de 2010.

Aos demais professores do Departamento de Anatomia do Instituto de Ciências Biomédicas da Universidade de São Paulo. 
À todos os funcionários do Departamento de Anatomia do Programa do Instituto de Ciências Biomédicas da Universidade de São Paulo, o profissionalismo e cordialidade são características a se destacar em todos.

Aos funcionários da Biblioteca e do Biotério do Instituto de Ciências Biomédicas da Universidade de São Paulo, pela excelência na prestação deste serviço.

Aos que aqui me acolheram, quando eu cheguei para fazer parte do Laboratório de Anatomia Funcional Aplicada à Clínica e Cirurgia LAFACC/VQM, Carlos Eduardo Seyfert, Cibele Maciel de Miranda, Dorival Terra Martini, Josemberg da Silva Baptista, Ricardo Bragança de Vasconcellos Fontes e William Paganini Mayer, a experiência de vocês faz muita falta para o laboratório, com vocês eu aprendi muitas coisas em muito pouco tempo, muito obrigado pela paciência e as milhares de ajudas prestadas.

Aos amigos de praticamente todos os dias, que além de tentar fazer ciência, também estão sempre prontos para falar um pouco da vida e farrear um pouco, Bruna Cecília Caixeta de Oliveira, Cleyton Roberto Sobrinho, Eduardo Henrique Beber, Flávio Silva Tampelini, Karina do Valle Marques, Luciano Gonçalves, Marcelo Arthur Cavalli, Paulo Henrique de Matos Alves, Regina de Sousa Bolina Matos, Ricardo Bandeira, Ricardo Eustáquio da Silva, Sabrina Caixeta de Oliveira, Thelma Renata Parada Simão e Valquíria Barboza Mariotti, graças à convivência com vocês eu pude me distrair, dar boas risadas e concluir mais este objetivo na minha vida, muito obrigado pelos vários favores e conselhos e até mesmo por muitas vezes discordarem de mim! 
Aos amigos e colegas que conheci ao longo dos anos no LAFACC/VQM, Adriano Polican Ciena, Aline Gonçalves, Aline Rosa Marosti Bobna, Allan Benedito Bonani, Ana Paula Cordó, Caroline Gebra Boleta, Caroline Emy Shibata, Cristina de Sousa Bolina, Cristina Eusébio Mendes, Diana Alves de Oliveira Vono, Giovanna Affonso de Campos, Guilherme Cotomacci, Isabela de Ugo Luques, Josy Alvarenga Cal Rosa, Kelly Palombit, Kátia Aparecida da Silva Viegas, Leonardo Ferreira Liberti, Lynda Jhailú Tamayo Arango, Luciana Senna Simões, Lucilene Ferreira Luiz, Luiz Henrique Silveira Rodrigues, Marcos Vinícius da Silva, Márcia Sanae Mizuno, Márcio Cristófaro, Mariana Pazos Henrique Sedo, Maritza Alves de Sousa Coura, Mateus Elias Pacheco, Milena Fernandes de Freitas, Paulo Alexandre Galvanini, Simone Piccoli, Thais Cristina Souza de Oliveira, Vânia do Carmo Gonçalves Furlani e Willian Grassi Bautz, muito obrigado pelo ótimo ambiente de convívio no LAFACC/VQM.

À Fundação de Amparo à Pesquisa do Estado de São Paulo (FAPESP) pelo projeto concedido para o desenvolvimento do presente estudo.

À Coordenação de Aperfeiçoamento de Pessoal de Nível Superior (CAPES) pela bolsa concedida em parte da Pós-Graduação.

À todos que por ventura eu tenha esquecido de citar e que me auxiliaram, os meus sinceros agradecimentos. 
"Qualquer homem pode tornarse grande, se realizar as coisas mais simples da vida, animado de um forte e sincero desejo de ser útil aos outros, seja qual for sua profissão." 


\section{RESUMO}

HABACUQUE, T. S. S. Aspectos estruturas, ultraestruturais e quantitativos dos efeitos da desnutrição protéica pré e pós-natal e da renutrição pósnatal no plexo ganglionar da traquéia de ratos. 2010. $141 \mathrm{f}$. Dissertação (Mestrado em Ciências Morfofuncionais) - Instituto de Ciências Biomédicas, Universidade de São Paulo, São Paulo, 2011.

A desnutrição é responsável pela metade das 11 milhões de crianças abaixo de 5 anos de idade que falecem todo ano por causas evitáveis nos países em desenvolvimento. Sabe-se que a desnutrição é fator determinante para instalação de doenças do sistema respiratório e que altera vários componentes do sistema nervoso de diversos plexos. Na presente pesquisa avaliou-se os efeitos da desnutrição protéica pré e pós-natal e renutrição pós-natal no plexo ganglionar da traquéia de ratos. Foram utilizados filhotes machos separados nos seguintes grupos: nutridos (N) com $20 \%$ de caseína (protéica), desnutridos (D) com $5 \%$ de caseína (hipoprotéica) e renutridos (R) que receberam ração hipoprotéica até $021^{\circ}$ dia, passando a receber dieta normoprotéica até completarem os 42 dias. Os espécimes foram avaliados por meio de técnicas histoquímicas (Nicotinamida adenina dinucleotídeo diaforase, NADH-d; Nicotinamida adenina dinucleotídeo fosfato diaforase, NADPH-d; e Acetilcolinesterase, AChE; $n=45$ ), técnicas imuno-histoquímicas (Substância $P$, SP; e Peptídeo Intestinal Vasoativo, VIP; $n=18$ ) e microscopia eletrônica de varredura (MEV; $n=9$ ). $O$ peso corporal do grupo $\mathrm{N}$ foi maior que dos grupos $\mathrm{D}$ e $R$, entre estes o peso do grupo $R$ foi maior $(p<0,05)$, o mesmo ocorreu com 0 peso traqueal, todavia a razão peso traqueal/peso corporal apresentou-se menor para o grupo $\mathrm{R}(\mathrm{p}<0,05)$. Destaca-se a fraca reatividade à $A C h E$ e ao VIP dos neurônios do grupo D. Não houve diferença entre os grupos estudados com relação ao número de neurônios e gânglios reativos à NADH-d e NADPH$d(p>0,05)$. $O$ número de neurônios por gânglio reativos à $N A D H-d$ do grupo $D$ foi maior que no grupo $R(p<0,05)$, sem haver diferença com o grupo $N$. A área do perfil neuronal foi maior nos animais nutridos quando comparado com os grupos $\mathrm{D}$ e $\mathrm{R}$ reativos à NADH-d e NADPH-d $(p<0,05)$. Os gânglios do grupo $\mathrm{N}$ reativos à $\mathrm{NADH}-\mathrm{d}$ apresentaram-se maiores que aqueles dos grupos $\mathrm{D}$ e $\mathrm{R}$ $(p<0,05)$, entretanto não houve diferença entre os grupos ( $N, D$ e R) quando comparada a área do perfil dos gânglios reativos à NADPH-d. Foi verificada uma distribuição heterogênea dos componentes do plexo traqueal, de modo que na metade torácica da traquéia havia cerca de $80 \%$ dos neurônios e gânglios reativos à NADH-d e NADPH-d. Não foi possível observar diferença da área média do perfil dos neurônios reativos à NADH-d entre as metades torácica e cervical da traquéia, porém quando comparado o perfil dos gânglios reativos NADH-d foi encontrado maior média do perfil na metade torácica $(p<0,05)$. Para os neurônios e gânglios reativos à NADPH-d, a maior média do perfil foi encontrada na metade torácica da traquéia $(p<0,05)$. A desnutrição protéica alterou o desenvolvimento dos animais e de componentes do plexo traqueal, e a renutrição foi responsável pela recuperação parcial de alguns aspectos.

Palavras-chave: Traqueia. Desnutrição. Morfometria. Renutrição. Ultraestrutura. 


\begin{abstract}
HABACUQUE, T. S. S. Structural, ultrastructural and quantitative aspects from pre and postnatal protein deprivation and postnatal refeeding effects on ganglioned trachea plexus of the rats. 2010. $141 \mathrm{p}$. Master thesis. (Morphofunctional Sciences) - Instituto de Ciências Biomédicas, Universidade de São Paulo, São Paulo, 2011.

Malnutrition is responsible for half of the 11 million children under age 5 who die every year from preventable causes in developing countries. It is known that malnutrition is a determinant factor for plant diseases of the respiratory system and amending various parts of the nervous system of various plexuses. In the present study evaluated the effects of protein malnutrition pre and postnatal and postnatal renutrition ganglionic plexus of the trachea of rats. We used male pups separated into the following groups: nourished $(N)$ with $20 \%$ casein (normal protein), undernourished (UN) with $5 \%$ casein (low protein) and renourish $(R)$ receiving low protein diet until day 21 , becoming receiving normal diet until they reached 42 days. The specimens were evaluated by histochemical techniques (nicotinamide adenine dinucleotide diaphorase, $\mathrm{NADH}-\mathrm{d}$; nicotinamide adenine dinucleotide phosphate diaphorase, NADPH-d; and acetylcholinesterase, $\mathrm{AChE} ; \mathrm{n}=45$ ), immunohistochemical techniques (Substance P, SP; and Vasoactive Intestinal Peptide, VIP; $n=18$ ) and scanning electron microscopy (SEM; $n=9$ ). Body weight was higher in group $N$ than in groups UN and R, among them the weight of the R group was higher $(p<0.05)$, the same happened to the tracheal weight, however the reason tracheal weight/body weight is lower for the $R$ group $(p<0.05)$. We highlight the weak reactivity to AChE and VIP neurons in group UN. There was no difference between groups regarding the number of neurons and ganglia of reactive $\mathrm{NADH}-\mathrm{d}$ and NADPH-d ( $p>0.05$ ). The number of ganglion neurons by NADH-d reactive to group $U N$ was higher than in group $R(p<0.05)$, with no differences with the group $\mathrm{N}$. The area of neuronal profile was higher in fed animals when compared with groups UN and R reactive to NADH-d and NADPH-d $(p<0.05)$. The ganglia of the $\mathrm{N}$ group reactive $\mathrm{NADH}-\mathrm{d}$ were higher than those in groups $U N$ and $R(p<0.05)$, although there was no difference between groups $(N, U N$ and $\mathrm{R}$ ) compared to the profile area of ganglia reactive to NADPH-d. It was observed a heterogeneous distribution of components of the tracheal plexus, so that half of the thoracic trachea was about $80 \%$ of neurons and ganglia of reactive NADH-d and NADPH-d. No difference was found in the area of the average profile of reactive NADH-d between the halves of the thoracic and cervical trachea, but when comparing the profile of reactive NADH-d ganglia was found higher mean profile in the thoracic half $(p<0.05)$. For ganglia neurons and reactive to NADPH-d, the highest profile was found in half of the thoracic trachea $(p<0.05)$. Protein malnutrition altered the development of animals and parts of the tracheal plexus, and renutrition was responsible for the partial recovery of some aspects.
\end{abstract}

Key words: Trachea. Undernutrition. Morphometry. Refeeding. Ultrastructure. 


\section{LISTA DE FIGURAS}

Figura 1 - Estante vertical de manutenção tradicional de gaiolas plásticas .47

Figura 2 - Representação esquemática da formação dos grupos experimentais .50

Figura 3 - Monitoramento dos animais. A - Estante vertical com 12 gaiolas metabólicas. B - Gaiola metabólica, com seus diversos reservatórios: garrafa de acondicionamento de água (seta vermelha), recipiente de armazenamento e verificação de desperdício de ração (seta amarela), tubo coletor de água desperdiçada (seta verde), tubo coletor de fezes (seta azul) e tubo coletor de urina (seta roxa)

Figura 4 - Comprimento dos animais de todos os grupos (N, D e R) 60

Figura 5 - Comparação gráfica do peso corporal dos animais de todos os grupos (N, D e R) (g) 61

Figura 6 - Representação gráfica do peso traqueal dos animais de todos os grupos (N, D e R) (g) 61

Figura 7 - Comparação gráfica da porcentagem de peso traqueal em razão ao peso corporal dos animais de todos os grupos (N, D e R) (\%) 61

Figura 8 - Características gerais do plexo traqueal de ratos. A - Vista posterior da traquéia e dos brônquios principais. A seta indica o nervo laríngeo recorrente. B - Troncos longitudinais exibindo gânglios ao longo do seu trajeto (setas). C-E - Gânglios de diferentes formatos e tamanhos, com quantidade variável de neurônios. (A - NADH-d; B-E - AChE). (Barras de calibração: A $500 \mu \mathrm{m} ; \mathbf{B}, \mathbf{C}, \mathbf{E}-100 \mu \mathrm{m}$; D - $50 \mu \mathrm{m})$ 64

Figura 9 - Características gerais do plexo traqueal de ratos. A - Troncos nervosos principais $(\mathrm{T})$ de trajeto longitudinal cujas ramificações assumem 
direção oblíqua ou transversal em relação ao longo eixo da traquéia, formando uma rede de malhas irregulares (setas longas). Notar os gânglios dispostos ao longo dos feixes (setas curtas). B - Região de bifurcação da traquéia em brônquios principais onde se observa a continuidade dos feixes nervosos principais do plexo traqueal, bem como dos gânglios e da malha ( $T$ - traquéia; $\mathrm{P}$ - brônquios principais). C - Continuidade da inervação nos brônquios lobares, com feixes e gânglios colinérgicos. No detalhe, fibras colinérgicas entre os anéis cartilagíneos (seta). (A-C - AChE). (Barras de calibração: A-C - $200 \mu \mathrm{m}$ ) 65

Figura 10 - Características gerais do plexo traqueal de ratos. A, B, D Observar a variedade de formatos dos gânglios relativos à quantidade de neurônios no seu interior. C - Neurônios contidos no interior dos feixes nervosos. Observar, em destaque, dois neurônios e seus prolongamentos intensamente reativos. (A-D - AChE). (Barras de calibração: A, B, D, C' - 20 $\mu \mathrm{m}, \mathbf{C}-50 \mu \mathrm{m})$ 66

Figura 11 - Características gerais do plexo traqueal evidenciado pela técnica da NADH-d do Grupo N. A - Gânglio alongado constituído por duas fileiras de neurônios de diferentes tamanhos e formatos. Notar os feixes de fibras nervosas (setas) paralelas ao gânglio e um tronco nervoso principal (cabeças de seta). B - Gânglio contendo neurônios pequenos (p), médios $(m)$ e grandes (g). C, D - Gânglios arredondados com poucos neurônios e grande quantidade de células satélites preenchendo o espaço entre os neurônios (círculo). (Barras de calibração: A-D - $50 \mu \mathrm{m}$ ) .68

Figura 12 - Plexo traqueal evidenciado pela técnica da NADH-d dos grupos $D$ (A, C) e R (B, D). A - Gânglio de tamanho grande contendo diversos neurônios. B - Gânglios com formatos e tamanhos diferentes (setas). Notar os feixes de fibras destinados aos gânglios (cabeças de setas), partindo de um tronco nervoso principal (*). C - Gânglio com amplos espaços (*) entre os neurônios de diferentes tamanhos. Notar a grande quantidade de neurônios pequenos (setas). D - Neurônios pequenos ( $p$ ), médios $(m)$ e grandes $(g)$ presentes no 
interior de um gânglio. (Barras de calibração: A-B - $50 \mu \mathrm{m}$; C-D - $20 \mu \mathrm{m}$ )

Figura 13 - Características gerais dos gânglios pertencentes ao plexo traqueal, evidenciados pela técnica NADH-d dos grupos N (A-B), D (C-D) e R (E-F). A-F - Gânglios com diferentes tamanhos e formatos. A-B - Gânglios apresentando estreita relação com feixe nervoso (seta). C-D - Gânglios com espaços amplos no seu interior $\left(^{*}\right)$. E-F - Gânglios com formato irregular, com grande quantidade de neurônios no seu interior. (Barras de calibração: A-F - $50 \mu \mathrm{m}$ )

Figura 14 - Características gerais dos neurônios que compõe o plexo traqueal, evidenciados pela técnica NADH-d dos grupos N (A-B), D (C-D) e R (E-F). A-F - Notar a variedade de formatos apresentado pelos neurônios de todos os grupos ( $N$, D e R). Observar prolongamentos axonais em muitos neurônios (setas). (Barras de calibração: A-F - $10 \mu \mathrm{m}$ ) .71

Figura 15 - Plexo traqueal evidenciado pela técnica da NADPH-d de animais do grupo N. A - Gânglio contendo neurônios de reatividade homogênea, destacando-se um agrupamento de células satélites (setas). B - Neurônios pequenos ( $p$ ), médios $(m)$ e grandes (g). C - Gânglio com poucos neurônios reativos e espaços $\left(^{*}\right)$, provavelmente preenchidos por neurônios não nitrérgicos. D - Feixe nervoso interganglionar espesso, contendo neurônios fracamente reativos (setas). (Barras de calibração: A, C, D - $50 \mu \mathrm{m}$; B - $20 \mu \mathrm{m}$ )

Figura 16 - Plexo traqueal evidenciado pela técnica da NADPH-d dos grupos D (A) e R (B-C). A - Gânglios de diferentes tamanhos (setas). Notar a interrelação a partir de um feixe nervoso principal (cabeças de setas). B - Aspecto geral de um gânglio contendo poucos neurônios com reatividade relativamente homogênea e espaços no seu interior ( $\left.{ }^{*}\right)$. C - Neurônios de diferentes formatos e tamanhos ( $p, m$ e g). Notar que, independentemente do tamanho, a intensidade de marcação é aparentemente a mesma em todos os neurônios. (Barras de calibração: A, C - $50 \mu \mathrm{m}$; B - $20 \mu \mathrm{m}$ ) 
Figura 17 - Características gerais dos gânglios pertencentes ao plexo traqueal, evidenciados pela técnica NADPH-d dos grupos N (A-B), D (C-D) e R (E-F). AF - Diversos formatos e tamanhos dos gânglios de todos os grupos (N, D e R). A - Gânglios com grande quantidade de neurônios, contendo neurônios fortemente (seta curta), moderadamente (cabeça de seta) e fracamente reativos (seta longa). B - Gânglio alongado, paralelo a um feixe de fibra nervosa. C - Gânglio com formato espiral, constituído por neurônios pequenos (p), médios (m) e grandes (g). D - Gânglio apresentando amplos espaços ( ${ }^{*}$ ) entre neurônios com variadas intensidades de marcação. E - Gânglio apresentando neurônios com reatividade homogênea. F - Gânglio com grande quantidade de neurônios, notar a presença de um feixe nervoso muito próximo. (Barras de calibração: A-E - $50 \mu \mathrm{m}$; F - $100 \mu \mathrm{m}$ ) .75

Figura 18 - Características gerais dos neurônios componentes do plexo traqueal, evidenciados pela técnica NADPH-d de todos os grupos $N(A-B), D$ (C-D) e R (E-F). A-F - Neurônios intensamente reativos, circundados por diversas células satélites. Notar a variedade de formatos apresentados pelos neurônios de todos os grupos ( $N, D$ e R). Observar neurônios com formato alongado, ovóide, circular. (Barras de calibração: A - $25 \mu \mathrm{m}$; B-F - $10 \mu \mathrm{m}$ ) .76

Figura 19 - Plexo traqueal evidenciado pela técnica da AChE de animais do grupo N. A - Gânglio com grande quantidade de neurônios exibindo reatividade intensa (seta longa) ou moderada (seta curta). B - Neurônios com citoplasma fracamente reativo. Comparar com o neurônio da figura $\mathbf{C}$, intensamente reativo. (Barras de calibração: A - $50 \mu \mathrm{m}$; B-C - $5 \mu \mathrm{m}$ ) .78

Figura 20 - Plexo traqueal evidenciado pela técnica da AChE de animais do grupo D. A, C - Gânglios com grande quantidade de neurônios, muitos deles exibindo fraca reatividade (setas). B, E - Neurônios intensamente reativos observados no interior dos feixes nervosos. D - Gânglio com apenas dois neurônios, exibindo fraca reatividade. (Barras de calibração: A-E - $20 \mu \mathrm{m}$ ) 
Figura 21 - Plexo traqueal evidenciado pela técnica da AChE de animais do grupo R. A, B - Gânglios com grande quantidade de neurônios intensamente reativos. C - Gânglio pequeno, contendo neurônios intensamente reativos. D Neurônio intensamente reativos contido no interior de um feixe nervoso. (Barras de calibração: A-D - $20 \mu \mathrm{m}$ )

Figura 22 - Fotomicrografias exibindo a imunorreatividade do plexo traqueal à SP ( $A, C$ e E) e ao VIP (B, D e F) dos grupos N (A-B), D (C-D) e R (E-F). Notar a variabilidade dos gânglios quanto ao tamanho e número de neurônios e a proporção pequena de neurônios exibindo intensa reatividade (setas), exceto em $\mathbf{D}$, onde os neurônios apresentaram-se fracamente reativos ou com nenhuma reatividade. (Barras de calibração: A-F - $20 \mu \mathrm{m}$ )

Figura 23 - Eletronmicrografias de varredura do plexo traqueal. Aspectos gerais da malha constituída pelos feixes de fibras nervosas. A - Observar a disposição do feixe constituinte da malha primária (seta amarela) dirigindo-se aos espaços entre os anéis traqueais (setas verdes). B - Distribuição da malha do plexo, de aspecto pantográfico, sobre a musculatura traqueal. C - Em maior aumento, os aspectos dos feixes constituintes das malhas primária (seta amarela), secundária (seta azul) e terciária (seta vermelha). D - Destacam-se as delgadas fibrilas constituintes da malha terciária (seta vermelha) provenientes da malha secundária (seta azul). (Barras de calibração: A-D - $100 \mu \mathrm{m}$ )

Figura 24 - Constituintes do plexo traqueal evidenciados sob as técnicas de microscopia de luz (A) e eletrônica de varredura (B). Notar, em ambas as técnicas, a morfologia e a disposição dos neurônios no interior dos gânglios $(G)$, bem como a estreita relação destes com o feixe de fibras nervosas constituintes das malhas do plexo $\left(^{*}\right)$. (A - NADPH-d). (Barras de calibração: A - $25 \mu \mathrm{m}$; $\mathbf{B}-30 \mu \mathrm{m})$ .85

Figura 25 - Constituintes do plexo traqueal evidenciados pelas técnicas de microscopia de luz (A) e eletrônica de varredura (B-D). Notar em A, os corpos neuronais (seta) no interior do gânglio $(G)$ e o feixe de fibras nervosas anexas 
(*). Em B, gânglio com cápsula parcialmente corroída e delgados feixes de fibras nervosas penetrando no seu interior (seta). C - Feixe espesso de fibras nervosas anexas ao gânglio $\left(^{*}\right)$ e corpos neuronais (seta) evidenciados através da cápsula do gânglio parcialmente corroída. D - Feixe de fibras nervosas das malhas do plexo $\left({ }^{*}\right)$ e fibrilas colágenas constituintes da cápsula ganglionar, remanescentes do processo de corrosão ao qual foi submetida. (A - NADPH-d). (Barras de calibração: A - $25 \mu \mathrm{m}$, B - $30 \mu \mathrm{m}$; C $-100 \mu \mathrm{m}$; D $-3 \mu \mathrm{m}$ )

Figura 26 - Eletronmicrografias de varredura evidenciando gânglios do plexo traqueal em diferentes fases do processo de corrosão da cápsula ganglionar. Notar em A, o início da corrosão, com os corpos neuronais salientando-se sob a cápsula. B-C - Fase mais adiantada, evidenciando-se os corpos neuronais e alguns resquícios das fibrilas colágenas da cápsula. D - Estágio avançado do processo de corrosão, onde se verifica o início da digestão dos corpos neuronais. (Barras de calibração: A - $30 \mu \mathrm{m}$; B - $20 \mu \mathrm{m}$; C - $100 \mu \mathrm{m}$; D - $10 \mu \mathrm{m}$ )

Figura 27 - Neurônios constituintes dos gânglios do plexo traqueal evidenciados pelas técnicas de microscopias de luz (A) e eletrônica de varredura (B-D). A, C - Notar os diferentes tamanhos dos corpos neuronais - $p$ : pequeno; m: médio; g: grande. Em $\mathbf{D}$ a seta indica um feixe da malha terciária interposto entre os corpos neuronais. (A - NADPH-d). (Barras de calibração: $\mathbf{A}$ $25 \mu \mathrm{m}$; B-C - $30 \mu \mathrm{m}$; D - $10 \mu \mathrm{m})$ 88

Figura 28 - Representação gráfica da média $( \pm D P)$ do número total de neurônios reativos à NADH-d nos grupos Nutrido (N), Desnutrido (D) e Renutrido (R) .89

Figura 29 - Representação gráfica da média $( \pm D P)$ do número total de gânglios reativos à NADH-d nos grupos Nutrido (N), Desnutrido (D) e Renutrido (R) 
Figura 30 - Representação gráfica da média $( \pm D P)$ da razão neurônios/gânglio reativos à NADH-d nos grupos Nutrido (N), Desnutrido (D) e Renutrido (R)

Figura 31 - Distribuição do número total $( \pm D P)$ de neurônios reativos à NADH-d nas metades superior e inferior nos grupos Nutrido (N), Desnutrido (D) e Renutrido $(\mathrm{R})$ 91

Figura 32 - Distribuição do número total $( \pm D P)$ de gânglios reativos à NADH-d nas metades superior e inferior nos grupos Nutrido (N), Desnutrido (D) e Renutrido (R)

Figura 33 - Distribuição da média $( \pm D P)$ da razão neurônios/gânglio reativos à $\mathrm{NADH}-\mathrm{d}$ nas metades superior e inferior nos grupos Nutrido (N), Desnutrido (D) e Renutrido (R) .92

Figura 34 - Representação gráfica da média $( \pm D P)$ do número total de neurônios reativos à NADPH-d nos grupos Nutrido (N), Desnutrido (D) e Renutrido $(\mathrm{R})$ 92

Figura 35 - Representação gráfica da média $( \pm D P)$ do número total de gânglios reativos à NADPH-d nos grupos Nutrido (N), Desnutrido (D) e Renutrido (R) 93

Figura 36 - Representação gráfica da média $( \pm D P)$ da razão neurônios/gânglio reativos à NADPH-d nos grupos Nutrido $(N)$, Desnutrido $(D)$ e Renutrido $(R)$

Figura 37 - Distribuição do número total $( \pm D P)$ de neurônios reativos à NADPHd nas metades superior e inferior nos grupos Nutrido $(N)$, Desnutrido (D) e Renutrido (R) 
Figura 38 - Distribuição do número total $( \pm D P)$ de gânglios reativos à NADPH-d nas metades superior e inferior nos grupos Nutrido (N), Desnutrido (D) e Renutrido $(\mathrm{R})$ 95

Figura 39 - Distribuição da média $( \pm D P)$ da razão neurônios/gânglio reativos à NADPH-d nas metades superior e inferior nos grupos Nutrido $(N)$, Desnutrido (D) e Renutrido (R) 95

Figura 40 - Distribuição da área média do perfil celular NADH-d reativos $\left(\mu \mathrm{m}^{2}\right)$ nos grupos Nutrido (N), Desnutrido (D) e Renutrido (R)

Figura 41 - Representação gráfica da média $( \pm D P)$ da área dos neurônios reativos à NADH-d nos grupos Nutrido (N), Desnutrido (D) e Renutrido (R)

Figura 42 - Distribuição da área média do perfil ganglionar NADH-d reativos $\left(\mu \mathrm{m}^{2}\right)$ nos grupos Nutrido $(\mathrm{N})$, Desnutrido (D) e Renutrido (R) 97

Figura 43 - Representação gráfica da média $( \pm D P)$ da área dos gânglios reativos à NADH-d nos grupos Nutrido (N), Desnutrido (D) e Renutrido $(\mathrm{R})$. 98

Figura 44 - Distribuição da área média $( \pm D P)$ de neurônios reativos à NADH-d nas metades superior e inferior nos grupos Nutrido (N), Desnutrido (D) e Renutrido $(\mathrm{R})$ 99

Figura 45 - Distribuição da área média do perfil neuronal NADH-d reativos $\left(\mu \mathrm{m}^{2}\right)$ nas metades superior e inferior nos grupos Nutrido (N), Desnutrido (D) e Renutrido (R) 
Figura 46 - Distribuição da área média $( \pm D P)$ dos gânglios reativos à NADH-d nas metades superior e inferior nos grupos Nutrido (N), Desnutrido (D) e Renutrido (R) 100

Figura 47 - Distribuição da área média do perfil ganglionar NADH-d reativos $\left(\mu \mathrm{m}^{2}\right)$ nas metades superior e inferior nos grupos Nutrido $(N)$, Desnutrido (D) e Renutrido $(\mathrm{R})$ 101

Figura 48 - Distribuição da área média do perfil celular NADPH-d reativos $\left(\mu \mathrm{m}^{2}\right)$ nos grupos Nutrido (N), Desnutrido (D) e Renutrido (R) 102

Figura 49 - Representação gráfica da média $( \pm D P)$ da área dos neurônios reativos à NADPH-d nos grupos Nutrido (N), Desnutrido (D) e Renutrido (R) 102

Figura 50 - Distribuição da área média do perfil ganglionar NADH-d reativos $\left(\mu \mathrm{m}^{2}\right)$ nos grupos Nutrido $(\mathrm{N})$, Desnutrido (D) e Renutrido (R)

Figura 51 - Representação gráfica da média $( \pm D P)$ da área dos gânglios reativos à NADPH-d nos grupos Nutrido (N), Desnutrido (D) e Renutrido (R) 104

Figura 52 - Distribuição da área média $( \pm D P)$ de neurônios reativos à NADPH-d nas metades superior e inferior nos grupos Nutrido (N), Desnutrido (D) e Renutrido $(\mathrm{R})$ 105

Figura 53 - Distribuição da área média do perfil neuronal NADPH-d reativos $\left(\mu \mathrm{m}^{2}\right)$ nas metades superior e inferior nos grupos Nutrido $(N)$, Desnutrido (D) e Renutrido $(\mathrm{R})$ 105 
Figura 54 - Distribuição da área média $( \pm D P)$ dos gânglios reativos à NADPH-d nas metades superior e inferior nos grupos Nutrido (N), Desnutrido (D) e Renutrido (R) . 106

Figura 55 - Distribuição da área média do perfil ganglionar NADPH-d reativos $\left(\mu \mathrm{m}^{2}\right)$ nas metades superior e inferior nos grupos Nutrido $(N)$, Desnutrido (D) e Renutrido (R) 


\section{LISTA DE ABREVIATURAS}

AChE - Acetilcolinesterase

D - Desnutrido

D_Cer

D_Tor

MEV - Microscopia Eletrônica de Varredura

$\mathrm{N}$ - Nutrido

N_Cer

N_Tor

NADH - Nicotinamida Adenina Dinucleotídeo

NADH-d - Nicotinamida Adenina Dinucleotídeo diaforase

NADPH - Nicotinamida adenina dinucleotídeo fosfato

NADPH-d - Nicotinamida adenina dinucleotídeo fosfato diaforase

NANC - Não adrenérgico não colinérgico

NBT - Nitro Blue Tetrazoliun

NO - Óxido Nítrico

NOS - Óxido Nítrico Sintase

PBS - Solução Tampão Fosfato

$\mathrm{R}$ - Renutrido

R_Cer

$\mathrm{R}$ Tor

SP - Substância P

VIP - Peptídeo Intestinal Vasoativo 


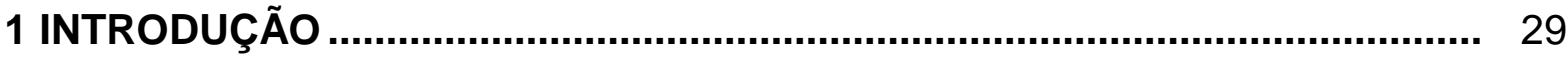

1.1 Considerações gerais sobre a desnutrição .............................................. 30

1.2 Efeitos da desnutrição nas partes do Sistema Nervoso............................ 34

1.3 Estrutura geral e inervação da traquéia de mamíferos .............................. 36

1.4 Diferentes formas de evidenciação do plexo traqueal correlacionadas

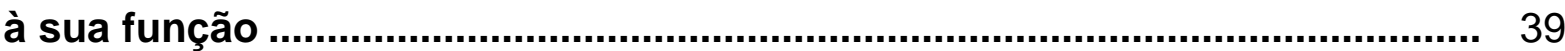

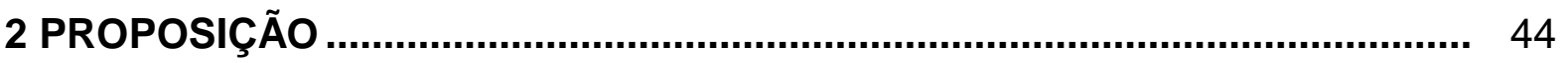

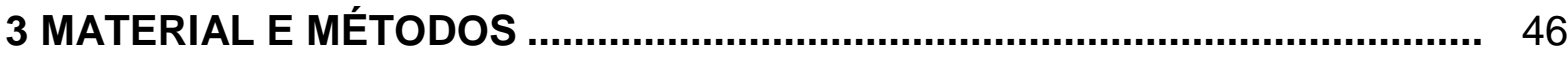

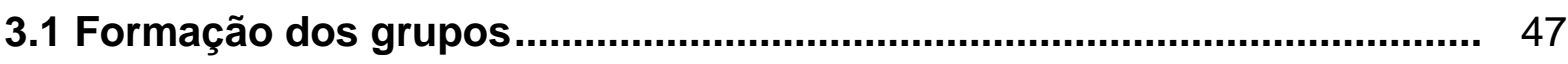

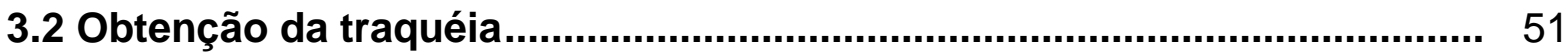

3.3 Técnica histoquímica da Nicotinamida Adenina Dinucleotídeo

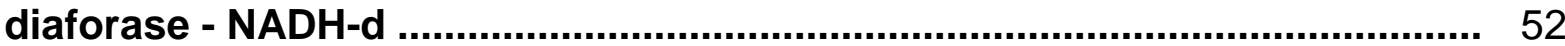

3.4 Técnica histoquímica da Nicotinamida Adenina Dinucleotídeo Fosfato

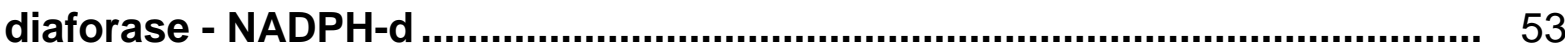

3.5 Técnica histoquímica da Acetilcolinesterase - AChE ............................... 53

3.6 Técnica imuno-histoquímica para Peptídeo Intestinal Vasoativo (VIP) e Substância P (SP).................................................................................. 54

3.7 Técnica da Microscopia Eletrônica de Varredura - MEV............................. 55

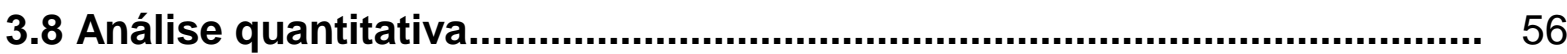

3.9 Tratamento estatístico .............................................................................. 56

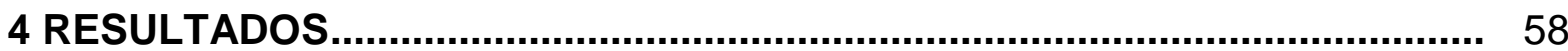

4.1 Características gerais dos animais: ninhadas, monitoramento e aspectos macroscópicos............................................................................. 59

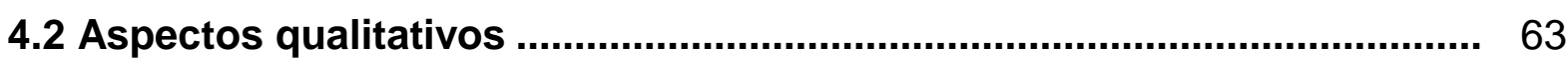

4.2.1 Características gerais do plexo traqueal................................................ 63

4.2.2 Morfologia dos gânglios e neurônios do plexo traqueal reativos à NADH-d. 
4.2.3 Morfologia dos gânglios e neurônios do plexo traqueal reativos à NADPH-d

4.2.4 Morfologia dos gânglios e neurônios do plexo traqueal reativos à AChE

4.2.5 Morfologia dos neurônios do plexo traqueal reativos ao VIP e à SP.... 81

4.2.6 MEV dos componentes do plexo traqueal .......................................... 83

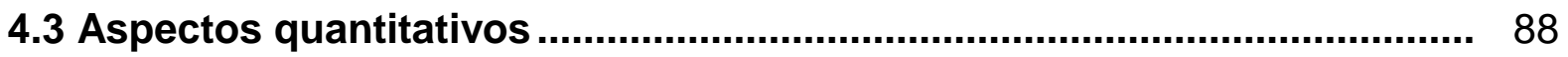

4.3.1 Número de neurônios e de gânglios reativos à NADH-d ......................... 88

4.3.2 Número de neurônios e de gânglios reativos à NADPH-d...................... 92

4.3.3 Área do perfil dos neurônios e gânglios reativos à NADH-d.................. 95

4.3.4 Área do perfil dos neurônios e gânglios reativos à NADPH-d ............. 101

5 DISCUSSÃO …................................................................................... 108

5.1 Aspectos gerais sobre a desnutrição...................................................... 109

5.2 Características gerais do plexo traqueal de ratos................................... 110

5.3 Morfologia dos neurônios e gânglios..................................................... 111

5.4 Considerações acerca da morfometria .................................................. 115

5.5 Aspectos quantitativos entre as metades da traquéia........................... 119

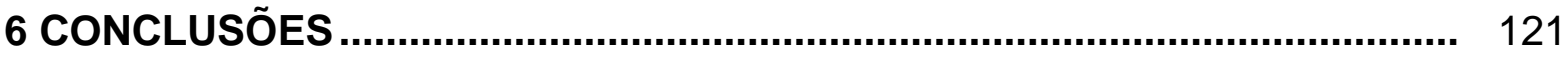

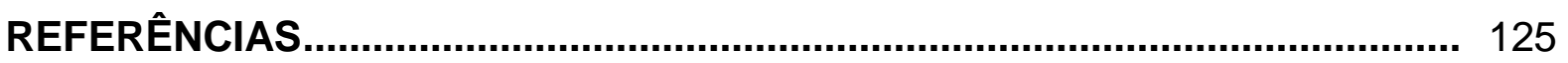




\subsection{Considerações gerais sobre a desnutrição}

Dois extremos de desordens alimentares da sociedade contemporânea são a inadequação por excesso, como no caso da obesidade mórbida, ou por deficiência, que é chamada de desnutrição severa. Desta última, são pouco conhecidos os efeitos nas estruturas do sistema respiratório (MORO et al., 2003).

Reconhece-se que, a nomenclatura clínica produziu uma grande variedade de sinonímias. Há casos em que se torna difícil estabelecer o que é geral e o que é específico e, mais ainda, o que se pretende valorizar conceitualmente, com a escolha de determinados unitermos, isto cria sérios obstáculos à linguagem. Não há, talvez, síndrome com mais rica sinonímia do que a desnutrição, sendo possível de maneira abrangente agrupar diversos termos, como: síndrome discrônica edematosa, despigmentação e edema, edema nutricional, síndrome subnutricional aguda, criança vermelha, kwashiorkor, pelagra infantil, edema infantil, má nutrição maligna, doença gordurosa do fígado, distrofia nutricional, edema de amido, edema de fome, atrofia pancreática com fígado gorduroso, caquexia edematosa, desnutrição de $3^{\circ}$ grau, distrofia pluricarencial hidropigênica, marasmo do desmame, distrofia, atrofia, atrepsia, caquexia, marasmo, decomposição (NÓBREGA, 1986).

Para Chandra (1992), a desnutrição é uma síndrome complexa, onde diversas deficiências ocorrem simultaneamente. De um modo geral, Monteiro (1995) define os indivíduos desnutridos como aqueles cujos organismos manifestam sinais clínicos provenientes da inadequação quantitativa (energia) ou qualitativa (nutrientes) da dieta ou decorrentes de doenças que determinem o mau aproveitamento biológico dos alimentos ingeridos.

Reconhece-se que, ao longo dos anos, a desnutrição tem sido um dos maiores, senão o maior problema de saúde pública em países em desenvolvimento, acometendo metade das 11 milhões de crianças menores de 5 anos de idade, que a cada ano, morrem de causas evitáveis: malária, diarreia e sarampo (COLLINS et al., 2006). Sendo assim, a desnutrição é a doença que mais mata crianças abaixo dos 5 anos de idade (SAWAYA, 2006). Particularmente, o Brasil pertence ao grupo de 42 países do mundo que respondem por $90 \%$ das mortes decorrentes da desnutrição (AMARAL et al., 2005). 
De Almeida et al. (1999) descreve que muitos métodos já foram propostos a fim de se poder, frente a um indivíduo ou a uma população, dizer qual o tipo e/ou intensidade do agravo nutricional que se sofre. De um modo geral, os métodos procuram classificar os casos de desnutrição em leves, moderados e graves e, para se chegar a esse escalonamento, existem basicamente dois tipos de meios: os meios indiretos, representados pelas estatísticas de saúde e, os diretos, que utilizam os dados clínicos, laboratoriais ou antropométricos.

O método antropométrico, que consiste em obter medidas corporais (peso, comprimento, perímetros cefálico e torácico, dobras cutâneas, entre outras) é utilizado para realizar comparações com as curvas de referência recomendadas pelas organizações nacionais e internacionais, como a Organização Mundial de Saúde (OMS) (DAMACENO; MARTINS; DEVICENZI, 2009; PETERSON; CHEN, 1990). Assim, também é possível avaliar a desnutrição por um ou mais indicadores nutricionais que são associados a um valor de corte, abaixo do qual, considera-se o estado nutricional como subnormal, assim como, determinar a gravidade e o tipo de desnutrição (COLLINS et al., 2006; PETERSON; CHEN, 1990).

O padrão antropométrico mais próximo do ideal seria aquele obtido de populações ou grupos étnicos cujos indivíduos tivessem usufruído a oportunidade de desenvolver, plenamente, seu potencial de crescimento, como é o caso das populações das áreas desenvolvidas do mundo ou dos grupos humanos de elevado padrão sócio-econômico, nas regiões subdesenvolvidas (ALMEIDA; RICCO, 1998).

No início da década de 70, importantes órgãos mundiais como a Organização das Nações Unidas para Agricultura e Fome (FAO) e a OMS passaram a se preocupar com a definição e a classificação dos níveis de carência protéica. Classificações estas que, entre outras características, precisavam ser simples e permitir comparações entre outras populações e que, especialmente no caso da desnutrição protéico-calórica, estabelecesse parâmetros qualitativos para determinar os padrões de severidade de crianças hospitalizadas e quantitativos, para estudos comunitários de prevalência e severidade (WATERLOW, 1972).

No Brasil, durante muito tempo, utilizou-se como referência para a determinação de estado nutricional, a curva de crescimento infantil publicada em 1977 pelo National Center for Health Statistics (NCHS). Construída a partir de banco de dados de pesquisas realizadas entre os anos de 1929 e 1975 nos Estados 
Unidos da América, sendo que, essa referência apresentava diversas limitações (VICTORA; ARAÚJO; DE ONIS, 2004).

Para tentar minimizar estas limitações, o Center for Disease Control and Prevention (CDC) reconstruiu o referencial de 1977 com uma série de modificações, lançando-o no ano 2000. Dentre as principais modificações, o aumento da amostra de crianças, dados de crianças em aleitamento materno foram incluídos e utilizaram de métodos estatísticos mais modernos (SOARES, 2003).

Recentemente, em 2006, a OMS propôs uma nova curva de crescimento infantil, construída com base em um estudo multicêntrico envolvendo seis países (Brasil, Gana, Estados Unidos da América, Índia, Noruega e Omã). Na amostra, as crianças e suas famílias foram avaliadas de acordo com diversos critérios de elegibilidade, dentre os quais, o aleitamento materno exclusivo ou predominante, pelo menos até os quatro meses de idade (DAMACENO; MARTINS; DEVINCENZI, 2009).

Considerando-se os valores de referência da OMS (WORLD HEALTH ORGANIZATION, 2006), a desnutrição severa é aquela que, após determinação da relação peso/altura, o valor obtido corresponde a 70\% (ou mais) abaixo da mediana estabelecida como padrão ou ainda a 3 ou mais desvios padrões abaixo dos valores de referência do NCHS.

Mais recentemente, no Brasil, o Instituto Brasileiro de Geografia e Estatística (2010) avaliou, entre outros aspectos, dados antropométricos desde o primeiro ano de vida. A avaliação foi feita por meio de classes de idade podendo ressaltar as seguintes informações sobre as crianças com menos de cinco anos: o déficit de altura (importante indicador de desnutrição) foi constatado em $6 \%$ das crianças no país, sendo mais expressivo em meninas no primeiro ano de vida $(9,4 \%)$, em crianças da região Norte $(8,5 \%)$ e na faixa mais baixa de rendimentos $(8,2 \%)$, que compreende rendimentos de até $1 / 4$ de salário mínimo per capita.

Os dados confirmam observações realizadas por Sawaya (2006), que destacou a altura como um indicador importante, não só para a determinação de desnutrição, como também um indicador sócio-econômico, sendo que, hoje se sabe que o fator ambiental é muito mais significativo do que o fator genético na determinação da estatura final de um indivíduo. 
Muitos casos avançados de crianças desnutridas são complicados por doenças infecciosas simultâneas, particularmente infecções respiratórias graves, diarréia e septicemia por gram-negativos (COLLINS et al., 2006). Almeida e Ricco (1998) destacam que a síndrome leva a uma dificuldade de tratamento de quase todas as outras doenças que acometem estas crianças, de forma especial as doenças respiratórias e intestinais.

Pelletier (1995) revisou 28 estudos epidemiológicos, verificando-se que cerca de $56 \%$ das crianças desnutridas faleciam por infecções respiratórias agudas e/ou outras infecções.

Por meio de pesquisas epidemiológicas realizadas nos municípios de São Paulo (SP) (MONTEIRO et al., 1986), Embu (SP) (ESCUDER et al., 1999) e Sobral (CE) (BARRETO; GRISI, 2010) identificou-se que crianças de zero a nove anos de idade, a maior prevalência de morbidades, referia-se a doenças do sistema respiratório, variando de $15,9 \%$ a $28,7 \%$ e que, em todas as populações, a presença da desnutrição infantil é fator determinante para a instalação destes acometimentos.

Chen et al. (2010) afirmam que a carência de outros substratos fundamentais para o desenvolvimento do sistema respiratório, como o ácido retinóico, podem ser responsáveis por atraso na maturidade do sistema, ou ainda, pela ausência de determinadas estruturas (WEl et al., 2009).

Trabalhos realizados com ratos (HARKEMA et al., 1984) e com cobaias (LECHNER; WINSTON; BAUMAN, 1986) submetidos a um período prolongado de desnutrição, descrevem que ocorre destruição das paredes alveolares com diminuição das áreas de troca gasosa alveolares que é consistente com a definição morfométrica de enfisema pulmonar (KERR et al., 1985; SAHEBJAMI; VASSALLO, 1979). Além disso, alterações do tecido conectivo estão associadas a uma redução no conteúdo da elastina pulmonar (KALENGA; EECKOUT, 1989), característica comum de portadores de enfisema pulmonar.

Pacientes desnutridos, sem doença pulmonar, demonstram diminuição da força muscular respiratória, da ventilação voluntária máxima e da capacidade vital (MURCIANO et al., 1994). A desnutrição provoca fraqueza dos músculos respiratórios, principalmente do diafragma, com diminuição da força e da resistência (ARORA; ROCHESTER, 1982), parcialmente relacionada, com a perda de sua massa muscular. A perda de massa, no entanto, não parece ser o único mecanismo 
envolvido na disfunção muscular. Sendo que, a desnutrição também provoca uma redução significativa no consumo de oxigênio mitocondrial (MATECKI et al., 2002).

Ezzell e Jensen (2000) e Pingleton (2001) descreveram que a associação de fraqueza muscular respiratória, com redução da ventilação e diminuição da função imunológica pode levar a falência hipercapnica respiratória, a dificuldade de desmame da ventilação mecânica, diminuição da capacidade de tossir e, consequentemente, um aumento no risco de atelectasias e pneumonias subsequentes em pacientes com qualquer tipo de doença respiratória.

Estas mudanças estruturais no parênquima pulmonar e na musculatura respiratória levam a alterações da complacência pulmonar, responsáveis por reduzir a mecânica respiratória, que se encontra prejudicada em animais submetidos à desnutrição (DIAS et al., 2004).

\subsection{Efeitos da desnutrição nas partes do Sistema Nervoso}

À época do desenvolvimento estrutural dos componentes das partes do sistema nervoso, diferentes fatores extrínsecos podem produzir, em determinadas situações, alterações no substrato neurofisiológico, muitas vezes irreversível. Dentre esses fatores, sem dúvida, destaca-se a desnutrição que, dependendo de sua intensidade, do momento em que ocorre e da sua duração, pode causar, principalmente, em órgãos e tecidos que se encontram em uma fase de desenvolvimento acelerado, efeitos deletérios que não podem ser completamente recuperados nem mesmo pela realização de uma subsequente reabilitação nutricional (DEUCHARS; MORRISON; MICHAEL, 1995; SHINGLETON, 2010; CULLEY; LINEBERGER, 1968; FISH; WINICK, 1969; HEDLEY-WHITE; MEUSER, 1971; CORDERO et al., 1986)

Os efeitos da desnutrição são descritos principalmente nos componentes da parte central do sistema nervoso (SNC), onde foram verificadas no encéfalo reduções significativas no seu peso (WATVE; YAJNIK, 2007; HEDLEY-WHITE; MEUSER, 1971; ALBRECHT MAY, 2008; CORDERO et al., 1986), no número de neurônios multipolares do córtex e da medula espinal (SHRADER; ZEMAN, 1969), no tamanho do pericário e volume da árvore dendrítica de células piramidais do 
córtex occipital (CORDERO et al., 1986) e ainda no grau de mielinização dos neurônios encefálicos (DEUCHARS; MORRISON; MICHAEL, 1995; WATVE; YAJNIK, 2007; HARRIS; WILCE; BEDI, 2000).

$\mathrm{Na}$ parte periférica do sistema nervoso (SNP) foi relatado por Matheson (1970) e Hedley-White e Meuser (1971), que a desnutrição pós-natal altera o desenvolvimento da bainha de mielina do nervo ciático de ratos. Estudos eletromiográficos realizados por Ghosh et al. (1979), demonstraram que a desnutrição, afeta a velocidade de condução dos impulsos nervosos em nervos de crianças. Nicoll, Bedi e Wigmore (1991) mediram os diâmetros totais de nervos ópticos mielinizados de ratos submetidos à desnutrição pré e pós-natal e observaram uma redução irreversível da bainha de mielina. Oldfors (1981), verificou degeneração compatível com degeneração Walleriana na parte distal dos nervos e Silva et al. (1987), demonstraram uma redução de 50\% na velocidade de condução do nervo ciático de ratos submetidos a uma dieta hipoprotéica. Cornblath e Brown (1988) observaram no nervo tibial posterior de ratos uma menor quantidade de fibras de grande diâmetro, bem como áreas endoneurais menores e regiões internodais mais curtas.

$\mathrm{Na}$ divisão autônoma do sistema nervoso (SNA) Schäfer e Friede (1988) observaram a diminuição do número de lamelas das fibras nervosas mielínicas em ratos submetidos à desnutrição pré-natal. Uma redução de $27 \%$ no número de neurônios do plexo mioentérico foi determinada por Santer e Conboy (1990) no intestino delgado de ratos adultos, cujas mães sofreram restrição na dieta durante as duas últimas semanas de gestação. Em ratos jovens, Castelucci et al. (2002a), Gomes et al. (2006) e Gréggio et al. (2010), também verificaram uma redução no número de neurônios entéricos, respectivamente, no intestino grosso, intestino delgado e esôfago. A redução do tamanho do neurônio superior de filhotes cujas mães foram desnutridas foi relatada por Conboy, Santer e Swift (1987), e a diminuição do tamanho do corpo celular do neurônio foi descrita por Brandão (1998) ao estudar no plexo mioentérico do intestino delgado de ratos, os efeitos da desnutrição protéica pré e pós-natal. No gânglio cervical superior de ratos submetidos a uma dieta hipoprotéica por um período de trinta dias ocorre um decréscimo significativo no conteúdo protéico dos gânglios e, principalmente, nas enzimas sintetizadoras dos neurotransmissores (GAETANI et al., 1977). 


\subsection{Estrutura geral e inervação da traquéia de mamíferos}

A traquéia é formada por anéis cartilagíneos na sua face ventro-lateral e, na face posterior, por uma parte membranácea constituída por musculatura lisa (BALUK; GABELLA, 1989a).

Diferente da distribuição observada na traquéia de humanos, o epitélio pseudo-estratificado colunar ciliado em ratos, apresenta-se ciliado somente na parte distal, próximo à bifurcação (JUNQUEIRA; CARNEIRO, 1999; ROSS; PAWLINA, 2008; KRINKE, 2000).

O tecido muscular da parede membranácea consiste em duas camadas de músculo liso, sendo, uma externa longitudinal e outra interna transversal. As fibras longitudinais constam de alguns feixes esparsos (GABELLA, 1969), enquanto que, as fibras transversas constituem o músculo traqueal. Este está organizado em feixes compactos, interconectados e entremeados por septos delgados de tecido conjuntivo, onde estão os vasos sanguíneos (GRAY, 1977).

Gabella (2004) descreve o sistema nervoso autônomo (SNA) organizado em grupos de gânglios, que podem ser esquematicamente subdividido em 4 grupos, nomeados, paravertebral, prevertebral, paravisceral e intramural. Especificamente os gânglios paraviscerais encontram-se na proximidade de algumas vísceras; os principais gânglios estão nos plexos cardíacos e pélvicos e outros gânglios menores estão presentes próximos da traquéia e brônquios.

Relativo à sua inervação, a traquéia recebe suprimento do nervo vago, da cadeia simpática e de um grupo de gânglios parassimpáticos situados na sua superfície dorsal. Esses gânglios são pequenos e, anatômica e fisiologicamente, são muito menos estudados do que os gânglios da cadeia simpática e dos plexos mioentérico e submucoso do tubo digestório (CHIANG; GABELLA, 1986; CASTELUCCl et al., 2002a; FONTES et al., 2004).

A distribuição e o tipo de inervação da traquéia são heterogêneos. De fato, um complexo padrão de inervação pode ser esperado para um órgão que contém diversas classes de tipos celulares; componentes estes, que incluem células de músculo liso, vasos sanguíneos, glândulas mucosas e o revestimento epitelial (BALUK; GABELLA, 1989a). 
Historicamente, Fisher (1964) descreveu que a primeira contribuição de certo valor a respeito da inervação traqueal de humanos foi realizada por Willis (1685), que descreveu nervos percorrendo a face externa da traquéia e, ainda, na camada muscular. Waters (1860) notou nervos penetrando na traquéia pela sua parede posterior e Kandarazki (1881) realiza a primeira descrição sobre gânglios pertencentes ao plexo nervoso, presentes na parede posterior da traquéia e, também, descreveu neurônios na parede anterior. Landois (1885) realizou a descrição de um plexo nervoso, com numerosos gânglios nas intersecções dos feixes nervosos. Ploschko (1897) confirmou a presença de uma concentração de gânglios na parede posterior, acrescentando que, os neurônios presentes neste plexo são do tipo multipolar e suprem a musculatura lisa e o tecido epitelial. Por meio de técnicas de coloração de azul de metileno, Larsell (1922) demonstrou a existência de gânglios no plexo bronquial de cães e coelhos, fato confirmado por Braeucker (1926) e Tscheliustkin (1927), que também observaram uma concentração de gânglios na parede membranácea e o aumento de complexidade do plexo nervoso nesta região da traquéia.

Utilizando preparados totais de membrana, Elftman (1943) descreveu gânglios na superfície da parede membranácea da traquéia de cães. Verificou, ainda, a presença de alguns gânglios entre as cartilagens, mas não subcondralmente.

Após um extenso estudo realizado em camundongos, Honjin (1954) descreveu um número considerável de pequenos gânglios seriados, interligados por nervos e incorporados na camada adventícia da parede dorsal da traquéia. Destacou a completa ausência de gânglios na face ventral, e que, pequenos ramos nervosos, provenientes do plexo traqueal situados posteriormente, assumem, entre as cartilagens, direção ventral.

Richardson, Ferguson (1976) realizaram estudos com fetos humanos e demonstraram a presença de gânglios nervosos peritraqueais e peribrônquicos, bem como, a presença de uma lâmina basal envolvendo as células nervosas e isolandoas do tecido circunjacente. Observaram, ainda, grande número de células de Schwann, junto aos gânglios. Em 1977, Dudzinska e Wozniak, ao realizarem estudos com fetos humanos, descrevem a traquéia recebendo ramos do nervo 
laríngeo recorrente, dos segmentos cervicais e torácicos superiores dos troncos simpáticos e, também, dos nervos cardíacos cervicais.

Utilizando métodos de microscopia eletrônica, Baluk, Fujiwara e Matsuda (1985), verificaram que o plexo nervoso da traquéia de cobaias, dispõe-se como um emaranhado irregular de feixes nervosos, com gânglios localizados numa camada de tecido conectivo situada, superficialmente, aos feixes da musculatura lisa do músculo traqueal. Enfatizam que, após realizarem cortes transversais do órgão, não detectaram gânglios na camada submucosa, profundamente à camada muscular ou aos anéis cartilagíneos.

Morfologicamente, os gânglios intrínsecos estão organizados na face posterior da traquéia de modo a formar duas divisões: os gânglios pertencentes ao tronco longitudinal, que pode apresentar-se isolado ou em número de dois, percorrendo toda a extensão da face posterior da parede membranácea (BAKER et al., 1986) e uma segunda camada de gânglios, fortemente associada com o músculo traqueal, distribuída como um emaranhado difuso denominado plexo muscular superficial (WU; DEY, 2006).

Chiang e Gabella (1986) demonstraram por métodos histoquímicos do plexo de camundongos, que os gânglios foram encontrados, exclusivamente, sobre a parte membranosa da traquéia, ou seja, na parte externa ou na superfície dorsal do músculo traqueal, não havendo gânglios sobre as cartilagens, entre as mesmas ou no interior da parede traqueal. Detectaram uma média de 235 neurônios que são relativamente pequenos, medindo cerca de $251 \mu^{2}$ e que aproximadamente $70 \%$ destes estavam localizados na metade torácica da traquéia.

Em nosso meio, Furlani et al. (2008) avaliaram as características morfoquantitativas do plexo traqueal do Calomys callosus, um roedor silvestre que é o hospedeiro natural do Trypanosoma cruzi (RIBEIRO, 1973). Verificaram também a presença de dois troncos nervosos principais longitudinais posteriores, e que, os gânglios estão envoltos por uma cápsula constituída por fibras colágenas e elásticas, com formato arredondado, alongado ou irregular, contendo até 45 neurônios. Quanto ao número estimado de neurônios, observou uma média de $279 \pm$ 51 com uma área média de $352 \mu \mathrm{m}^{2}$ para o perfil celular.

Há uma grande variação na inervação autônoma do trato respiratório entre os mamíferos, especialmente com relação às características anatômicas e fisiológicas. 
A distribuição da malha neuronal pode ser evidenciada por métodos histoquímicos, sendo esta malha mais simples em animas menores e tornando-se cada vez mais complexa nos maiores (KUSINDARTA; ATOJI; YAMAMOTO, 2004). Outra diferença que se pode acrescentar, é que, a inervação intrínseca da parede membranácea pode ser formada por diferentes números de camadas, por exemplo: duas camadas no rato (CHIANG, 1993), quatro camadas no furão (BAKER et al., 1986) e cinco camadas no cão (YAMAMOTO et al., 1998).

Baluk, Fujiwara e Matsuda (1985) enfatizaram a importância do estudo dos nervos e gânglios do trato respiratório para a compreensão das manifestações do tônus da musculatura lisa traqueobronquial, da permeabilidade vascular e do reflexo local, tanto em condições normais como em situações patológicas do sistema respiratório. Em pesquisa posterior, Baluk e Gabella (1989b) reforçam a utilização da traquéia de animais de laboratório como importantes modelos para estudar os efeitos da estimulação das vias aéreas menores e menos acessíveis.

\subsection{Diferentes formas de evidenciação do plexo traqueal correlacionadas à sua função}

As células nervosas e os nervos do sistema nervoso autônomo suprem entre outros órgãos, o coração e os vasos dos sistemas gastrointestinal, respiratório, urinário e os órgãos genitais. O sistema nervoso autônomo regula e coordena funções corporais baseados na atividade secretora das glândulas, na contração e relaxamento da musculatura lisa e do músculo cardíaco, e nas sensações provenientes das vísceras profundas (GABELLA, 2004).

Os órgãos que compõe o trato respiratório inferior são regulados por dois tipos de nervos autonômicos (simpático e parasimpático) que controlam a tensão da musculatura lisa, secreção das glândulas, função das células epiteliais, tônus vascular bronquial e reflexos traqueobrônquicos (CAMERON; COBURN, 1984; BARNES, 1986; COBURN, 1987). As funções das vias aéreas são influenciadas por clássicos mecanismos colinérgicos e adrenérgicos e por outro mecanismo neural, denominado mecanismo não adrenérgico não colinérgico (NANC) (KARLSSON, 1994). 
Assim, nos mamíferos, o tônus da musculatura das vias aéreas é controlado, primariamente, pela inervação colinérgica, e os estímulos colinérgicos produzem broncoconstrição e secreção de muco. Nos humanos, estimulação colinérgica também provoca vasodilatação (GROSS; SKORODIN, 1984; VAN DER VELDEN; HULSMANN, 1999). Inervação da cadeia simpática estão esparsos na via aérea de muitas espécies (VAN NIEUWSTADT; HAJER; BERUKINK, 1994) e ausente nos humanos (RICHARDSON, 1979; ZAAGSMA et al., 1987). Ainda assim, receptores adrenérgicos são abundantes nas vias aéreas e a ativação dos receptores adrenérgicos causa relaxamento da musculatura respiratória. Os receptores recebem epinefrina/noraepinefrina endógena por meio da corrente sanguínea. Estimulação destes receptores produz broncodilatação (VAN DER VELDEN; HULSMANN, 1999). O tônus da musculatura respiratória também é controlado por neutrotransmissores da inervação NANC, incluindo VIP, NO, SP, neuroquin A e neuroquin B (FURLANI et al., 2008).

Quanto à modulação química, os receptores adrenérgicos e colinérgicos de diferentes tamanhos são encontrados distribuídos aleatoriamente nas vias aéreas e entre outras células (NADEL; BARNES, 1984).

Para melhor estudo dos neurônios que compõe este plexo nervoso, técnicas de evidenciação histoquímica, imuno-histoquímica e imunofluorescência têm sido utilizadas ao longo dos anos. Dentre as técnicas clássicas de histoquímica para marcação de plexos nervosos, pode-se destacar a nicotinamida adenina dinucleotídeo diaforase (NADH-d) (GABELLA, 1969), que se baseia na reação de oxi-redução, catalisada pela enzima mitocondrial NADH-d. Para que ocorra a reação é fornecido, como substrato para a mesma, o NADH e o aceptor artificial de elétrons o Nitro Blue Tetrazolium (NBT). Ao receber os elétrons, o NBT precipita-se formando grânulos de formazana de cor azul e insolúveis, evidenciando, deste modo, o corpo celular de neurônios com maior atividade da enzima NADH-d positivos. De acordo com a literatura, esta técnica permite evidenciar parte do número total de neurônios, cerca de $80 \%$ da população neuronal (RÓMAN et al., 2001), assim como, a marcação por meio da imonurreatividade da proteína PGP 9.5 (EAKER; SALLUSTIO, 1994). Ainda a cerca do número de neurônios, Karaosmanoglu et al., (1996) relatam que a técnica imunocitoquímica para Fos-related antigen realiza a marcação de, aproximadamente, $65 \%$ da população total, sendo estes dados, 
menores do que quando comparado com as marcação obtidas pelo método de Giemsa (FURLAN et al., 1999; MIRANDA-NETO et al., 2000; SANT'ANA et al., 1997) ou com a coloração pelo azul cuprolínico (HOSTL; POWLEY, 1995; HEINICKE; KIERNAN; WIJSMAN, 1987), responsáveis pela marcação do número total de corpos neuronais de um plexo nervoso.

No plexo ganglionar traqueal evidencia-se uma grande variedade de neurotransmissores, dentre eles, o óxido nítrico (NO), que é um potente neurotransmissor inibitório, NANC (BULT et al., 1990; CANNING, 2006), que produz o relaxamento da musculatura lisa, dentre outros tecidos no trato respiratório (CANNING; FISCHER, 2001). A literatura científica valida o uso de técnicas histoquímicas para evidenciação de NO, já que a enzima Óxido Nítrico Sintase (NOS) co-existe com a $\beta$-nicotinamida adenina dinucleotídeo fosfato diaforase (NADPH-d) (SCHERER-SINGLER et al., 1983; SANTER, 1994; KERÄNEN et al., 1995). Estudos têm demonstrado o NO presente no plexo mioentérico de cobaias (FURNESS et al., 1994), no jejuno de ratos (SEYFERT, 2009), no esôfago (GRÉGGIO et al., 2010), nos pulmões de camundongos (GUEMBE; VILLARO, 1999) e no plexo traqueal de ratos (HASSALL; SAFFREY; BURNSTOCK, 1993; ANDREEVA; SHUMATOVA; MOTAVKIN, 2000).

O NO é um radical livre instável e atua como uma molécula mensageira em uma variedade de tecidos neurais e não neurais. Ele é sintetizado como um produto da conversão do precursor fisiológico L-arginina para citrulina, em uma reação catalisada por uma NOS constitutiva dependente de cálcio (MONCADA; PALMER; HIGGS, 1991; COMAN; YAPLITO-LEE; BONEH, 2008). O NO assim que é produzido, por ser lipofílico, atravessa a membrana das células efetoras. Nas células efetoras interage com a guanilato ciclase solúvel, ligando-se ao ferro da porção heme da enzima, resultando na mudança da guanosina monofosfato cíclico (GUEMBE; VILLARO, 1999). Este mensageiro secundário produz uma variedade de efeitos nas células alvo.

O NO não é considerado um transmissor convencional, pois não é armazenado em vesículas e, devido à sua natureza gasosa, atravessa facilmente as membranas biológicas, alcançando as células vizinhas logo que é produzida. Nos neurônios do plexo ganglionar traqueal, o NO desempenha importante função inibitória (KESLER; MAZZONE; CANNING, 2002; HASANEEN; FODA; SAID, 2006; 
CANNING, 2006), participando do controle do tônus da musculatura lisa (GUEMBE; VILLARO, 1999).

Os neurônios que produzem NO podem ser identificados através de técnicas imuno-histoquímicas para NOS (FABRICIUS et al., 1996; BOYER et al., 2007) ou através de técnicas histoquímicas onde ocorre a redução do NBT, formando uma formazana insolúvel (azul escuro), na presença de NADPH (SCHERER-SINGLER et al., 1983; CSERNI et al., 2009). A distribuição dos neurônios NADPH-d positivos é idêntica àqueles imunomarcados para NOS (BELAl et al., 1992; SANTER, 1994).

A NOS pode ser sintetizada tanto no corpo celular neuronal, quanto no terminal do axônio, tendo efeito direto pós-juncional sobre as células musculares lisas (STERN, 2004). Neurônios nitrérgicos são encontrados no sistema respiratório, digestório, urinário e genital, bem como no coração de diferentes espécies animais (GRAZDANOVIC; BAUMGARTEN; BRÜNING, 1994).

Ainda com relação ao plexo ganglionar traqueal, um dos principais neurotransmissores excitatórios é a acetilcolina, importante regulador das funções das vias aéreas (NAKAJIMA et al., 2000; GOSENS et al., 2004). A acetilcolina é sintetizada pela enzima acetiltransferase e sua degradação é efetuada por ação enzimática da acetilcolinesterase ( $\mathrm{AChE}$ ), após sua liberação na fenda sináptica (OSINSKI; BASS, 1993) podendo, a AChE, ser utilizada como um marcador de atividade colinérgica (GABELLA, 1994).

Em particular, a acetilcolina é um dos mais fortes broncoconstritores conhecidos e estimuladores da secreção das glândulas mucosas, mas também está envolvida na regulação dos mecanismos mais agudos, como o remodelamento das paredes das vias aéreas, como na presença de estímulos patológicos (KUMMER; LIPS; PFEIL, 2008).

Técnicas de microscopia eletrônica e histoquímica têm contribuído para esclarecer o papel do sistema adrenérgico e colinérgico. Como descrito até o momento, pode-se identificar, histoquimicamente, as fibras parassimpáticas (colinérgicas) pela atividade da AChE e as fibras simpáticas (adrenérgicas) pelo método da NADPH-d. Essas técnicas confirmam a ideia clássica de que, na maioria dos órgãos, a inervação autônoma é mista, parassimpática e simpática (MACHADO, 2002). 
Estudos mais recentes (PRABHA; MAYER; HAXHIU, 2004; WANG et al., 2006; HERNANDEZ et al., 2007), utilizando métodos de marcação neuronal, incluindo imuno-histoquímica, mostraram-se como marcadores neuronais sensíveis, porém, o método histoquímico clássico utilizando a AChE, como realizado por Baluk e Gabella (1989) para evidenciação do plexo traqueal é reconhecido como marcador de parte significativa dos neurônios dos plexos entéricos em geral. Desta forma, Domeneghini et al. (2004), por meio de reações de histoquímica e imunohistoquímica (AChE, ChAT e VAChT), para identificação dos neurônios colinérgicos constituintes do plexo mioentérico do intestino de cavalos observaram, de modo quantitativo, que as marcações em questão apresentaram resultados úteis e similares.

Do mesmo modo, pesquisadores como Yashuhara et al. (2007) utilizando técnicas histoquímicas e imuno-histoquímicas, a fim de evidenciar o plexo cardíaco, corroboram com os autores previamente citados, descrevendo resultados muito próximos entre as diferentes metodologias de detecção dos neurônios colinérgicos (AChE, ChAT e VAChT).

Em trabalho realizado em 1999, Dey, Satterfield e Altemus avaliaram a inervação da musculatura lisa e do epitélio da traquéia do furão, a fim de estabelecer o seu perfil neuroquímico, verificando, a presença de neurônios reativos à Substância $\mathrm{P}$ (SP) e ao peptídeo intestinal vasoativo (VIP).

Estudando as interações sinápticas que controlam as funções da traquéia do furão, numa tentativa de definir a anatomia neuroquímica dos seus circuitos neuronais, Massari e Haxhiu (2002) identificaram terminais aferentes contendo SP nas projeções de neurônios pré-ganglionares vagais.

Pelo até aqui exposto verifica-se que, além dos poucos trabalhos que descreveram a morfologia normal do plexo traqueal, ainda é assunto em aberto, a determinação da presença e a quantificação de neurônios que expressam os mais diferentes tipos de neurotransmissores. Além disso, na bibliografia consultada, nenhum trabalho que relacionasse o plexo traqueal com fatores extrínsecos capazes de alterar a sua morfologia normal, como é o caso da desnutrição foi encontrado. 
Com o uso de técnicas de microscopias de luz e eletrônica de varredura foram avaliados, no plexo traqueal de ratos jovens nutridos, desnutridos e renutridos:

1 - A morfologia dos neurônios e gânglios;

2 - O número total de neurônios e gânglios constituintes do plexo;

3 - O número e tamanho dos neurônios e gânglios nitrérgicos;

4 - A morfologia de neurônios e gânglios colinérgicos;

5 - A presença de neurônios imunorreativos à Substância $\mathrm{P}$ e ao VIP;

6 - A ultraestrutura dos neurônios ganglionares. 
3 MATERIAL E MÉTODOS 


\subsection{Formação dos grupos}

Foram utilizados Rattus norvegicus da linhagem Wistar Hannover (na proporção de 1 macho para 2 fêmeas), com idades entre 90 e 120 dias, com peso entre 280 e 320 gramas, provenientes do Biotério Central do Instituto de Ciências Biomédicas da Universidade de São Paulo (ICB/USP), e mantidos no Biotério do Departamento de Anatomia do mesmo instituto. A eleição dessa espécie deveu-se à consagração da mesma em pesquisas que estudam a nutrição, o metabolismo e os plexos autônomos em geral (GRÉGGIO, 2001; OLIVERA, 2006; BAPTISTA, 2008), além da facilidade de manipulação e suporte pré-existente no biotério no qual foram mantidos. Os animais foram mantidos em salas climatizadas, com temperatura controlada entre 23 e $25^{\circ} \mathrm{C}$ de maneira artificial, com ciclo claro/escuro de 12 horas, em gaiolas plásticas dispostas em estante vertical (Figura 1).

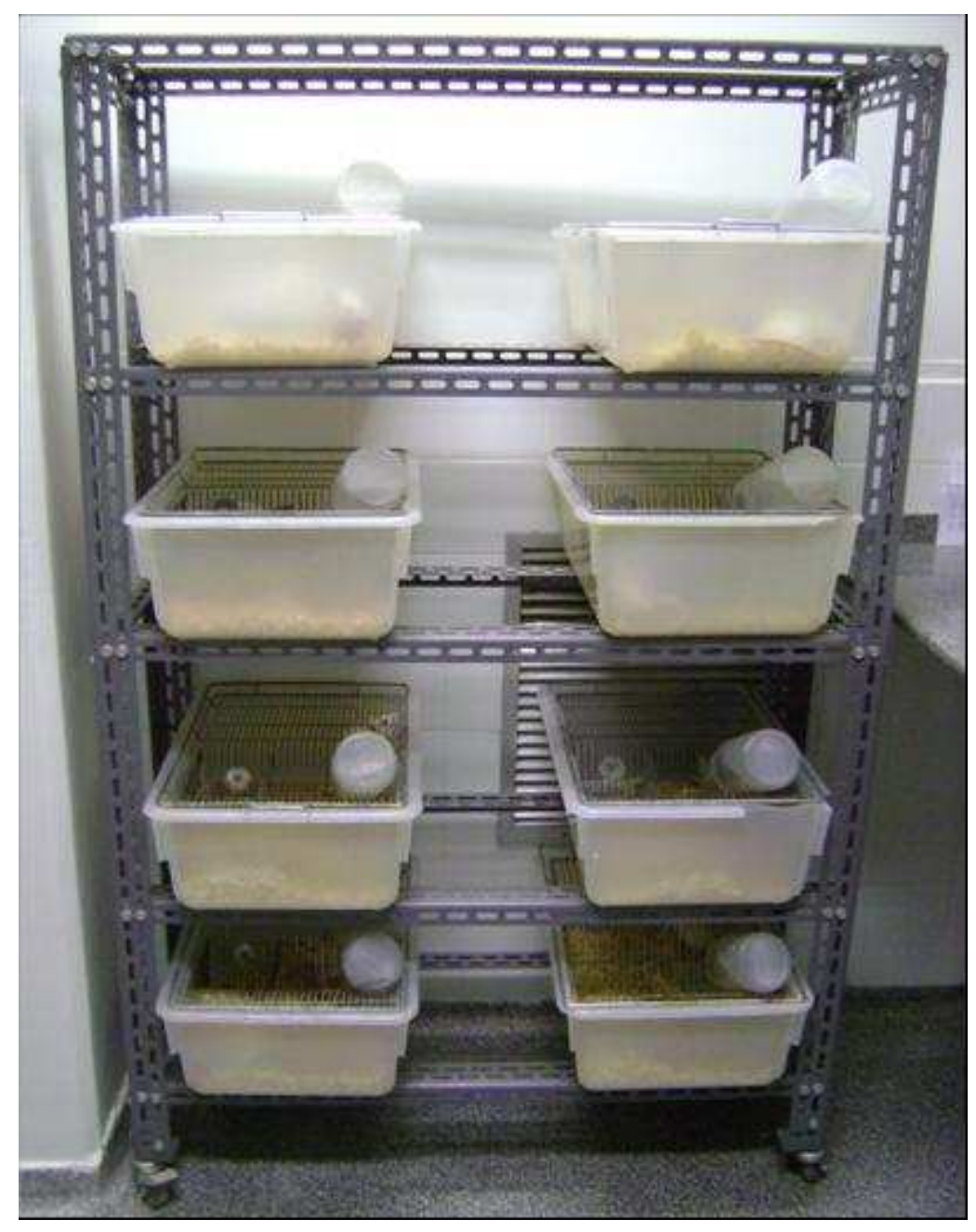

Figura 1 - Estante vertical de manutenção tradicional de gaiolas plásticas. 
Durante $o$ acasalamento, 1 macho foi mantido com 2 fêmeas durante um período de 10 dias (Sistema Poligâmico) onde, desde então, foi alterada a dieta padrão utilizada no biotério e oferecida sem restrições a ração para roedores (AIN-93G) estabelecida de acordo com o protocolo preconizado pelo "American Institute of Nutrition" (REEVES; NIELSEN; FAHEY-JÚNIOR, 1993), preparada em laboratório especializado ${ }^{1}$.

Para um grupo de animais (grupo nutrido - $\mathrm{N}$ ) ofereceu-se uma dieta denominada protéica contendo $20 \%$ de caseína e para outro, uma dieta denominada hipoprotéica (grupo desnutrido - D), com apenas 5\% de caseína. Após o acasalamento, as fêmeas foram separadas em gaiolas individuais de acordo com a dieta (respectivamente grupos $\mathrm{N}$ e D) e mantidas com as respectivas dietas durante a gestação e amamentação, juntamente com os filhotes, até que eles completassem 21 dias de vida extra-uterina, época determinada para o desmame.

Como as ninhadas apresentaram de 4 a 12 filhotes foi estabelecido, para padronização do experimento, um número mínimo de 4 e um número máximo de 6 animais por ninhada, priorizando a permanência da maior quantidade dos filhotes machos, sendo os animais excedentes, utilizados em demais estudos. A adoção desse critério permitiu a obtenção de animais com menor discrepância de massa corporal, sendo também uma tentativa de se evitar um elevado índice de mortalidade nas ninhadas do grupo $\mathrm{D}$, fenômeno este que ocorre tanto por condições intrínsecas devido ao tipo de privação protéica, como pelo fato de algumas mães se alimentarem dos próprios filhotes (neste caso, as ninhadas também foram excluídas). Ainda, o critério adotado procurou promover o mesmo tipo de estresse nas matrizes dos respectivos grupos, fazendo com que a ração se constituísse na única variável entre os grupos.

Aos 21 dias, a fim de serem submetidos às diversas técnicas, os filhotes machos foram pesados e identificados através de numeração na cauda, sendo dois de cada ninhada escolhidos aleatoriamente por sorteio, de forma a se utilizar somente animais não isogênicos. Os animais não eleitos, bem como as mães foram utilizados em outros estudos.

\footnotetext{
${ }^{1}$ Rhoster Indústria e Comércio Ltda, Araçoiaba da Serra, S.P., Brasil.
} 
A partir do $22^{\circ}$ dia, os animais que receberam a dieta protéica foram mantidos com a mesma até completarem 42 dias, passando a constituir 0 grupo controle, ou nutrido $(\mathrm{N})$; os animais tratados com a dieta hipoprotéica foram assim mantidos até completarem os 42 dias, constituindo o primeiro grupo experimental, ou desnutrido (D). Animais mantidos com a dieta hipoprotéica até os 21 dias e que passaram a receber a partir do $22^{\circ}$ dia a dieta protéica até atingirem a idade de 42 dias formaram o segundo grupo experimental, ou renutrido $(R)$.

Após a formação dos grupos, procedeu-se ao monitoramento metabólico em gaiolas metabólicas ${ }^{2}$, sendo mantido um animal por gaiola, sob estante vertical apropriada, onde foram mensurados diariamente e no mesmo horário, o peso corporal, a ingestão de água e ração, e a excreção dos animais. Os dados foram utilizados em outros estudos.

A figura 2 ilustra o protocolo experimental de maneira esquemática, adaptado de Baptista (2008), e a figura 3 demonstra o tipo de monitoramento utilizado na pesquisa.

\footnotetext{
${ }^{2}$ TECNIPLAST®, modelo 3700M081, Buguggiate, VA, Itália.
} 
Animais

Rattus norvegicus da linhagem Wistar Hannover

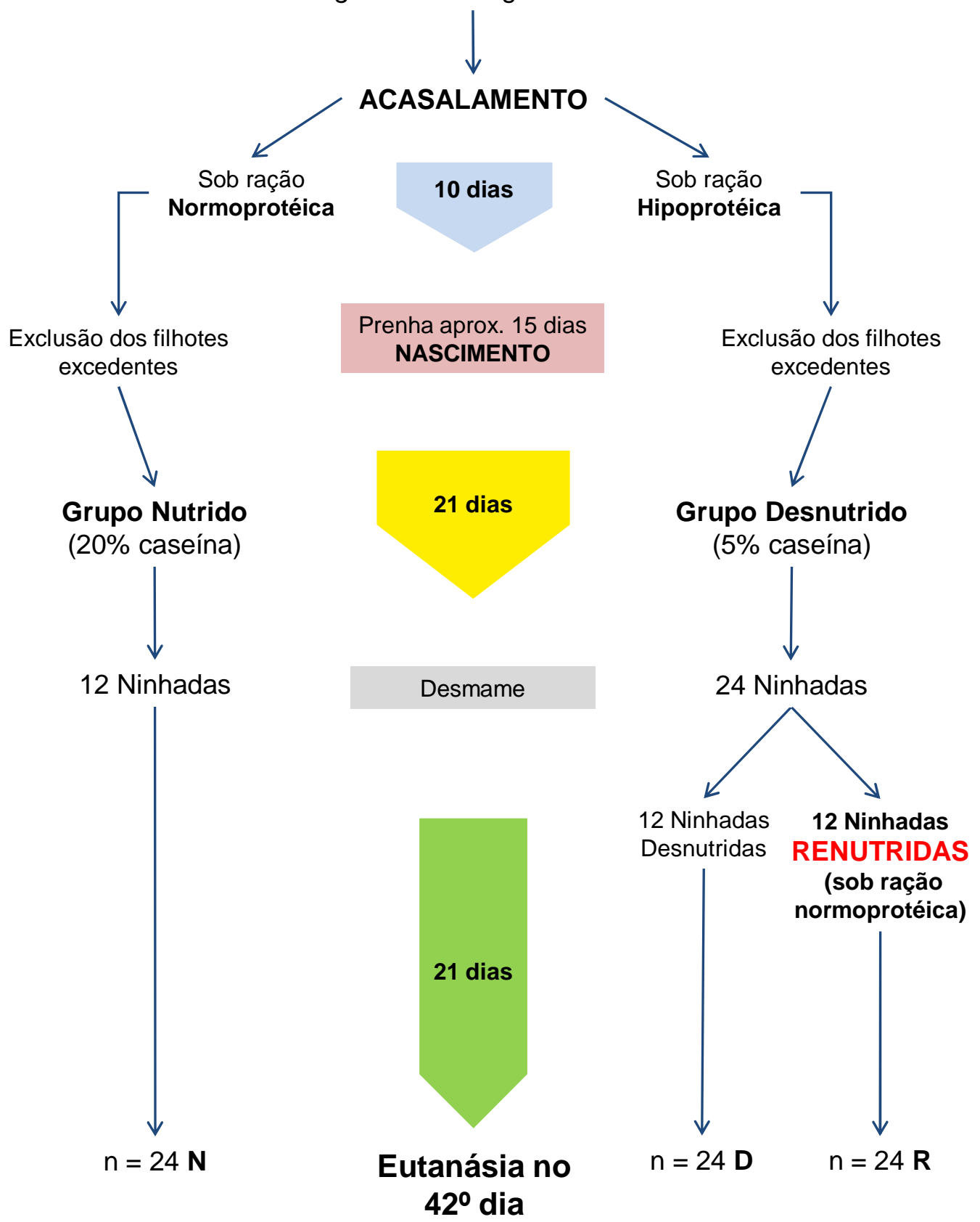

Figura 2 - Representação esquemática da formação dos grupos experimentais. 


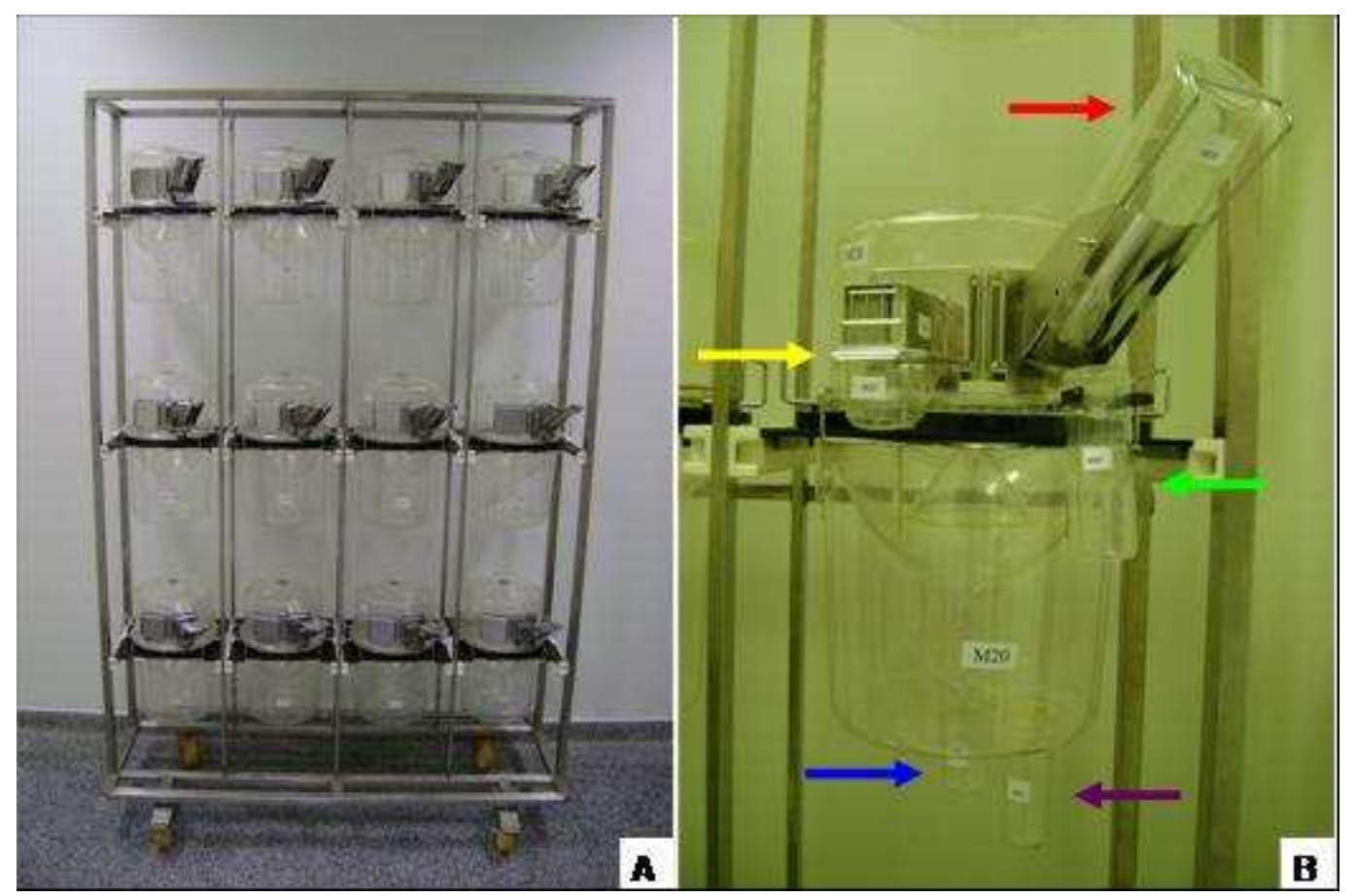

Figura 3 - Monitoramento dos animais. A - Estante vertical com 12 gaiolas metabólicas. B - Gaiola metabólica, com seus diversos reservatórios: garrafa de acondicionamento de água (seta vermelha), recipiente de armazenamento e verificação de desperdício de ração (seta amarela), tubo coletor de água desperdiçada (seta verde), tubo coletor de fezes (seta azul) e tubo coletor de urina (seta roxa).

\subsection{Obtenção da traquéia}

Todos os animais de cada grupo ( $N, \mathrm{D}$ e $\mathrm{R}$ ) foram submetidos à eutanásia em câmara de dióxido de carbono ${ }^{3}\left(\mathrm{CO}_{2}\right)$, tendo o seu peso determinado momentos antes da eutanásia.

O procedimento para a retirada da traquéia iniciou-se com uma incisão na pele do abdome em sua região mediana, próximo ao ângulo costal. Após a exposição do processo xifóide do osso esterno e atingir-se a cavidade peritoneal, procedeu-se a uma incisão transversal bilateral, paralela à margem costal, a fim de se expor as vísceras abdominais e o músculo diafragma cuja remoção permitiu adentrar a cavidade torácica, visualizando-se os pulmões e o coração, além dos ligamentos esternopericárdicos. A seguir foi realizada, desde a abertura inferior até a abertura superior do tórax, uma incisão bilateral das costelas em forma de "V" invertido permitindo rebater superiormente, com

\footnotetext{
${ }^{3}$ Biotério do Departamento de Anatomia do ICB/USP.
} 
o auxílio de uma pinça, o plastrão esternocostal. O bloco contendo os pulmões, o coração e a traquéia foi então retirado, após incisão transversal completa da laringe. A traquéia (com a origem dos brônquios principais) foi dissecada sob lupa cirúrgica, com o auxílio de pinças e tesoura oftalmológicas, pesada e submetida às diversas técnicas.

\subsection{Técnica histoquímica da Nicotinamida Adenina Dinucleotídeo diaforase - NADH-d}

Para a realização desta técnica foram utilizados cinco animais de cada grupo ( $N, D$ e R). Após a ligadura dos brônquios, foi injetada na luz da traquéia quantidade suficiente de solução de $\mathrm{Krebs}(\mathrm{pH} 7,4)^{4}$, que foram mantidas na mesma solução por 30 minutos. Em seguida, os espécimes foram imersos por 5 minutos em solução permeabilizante (Krebs contendo Triton $X-100^{5}$ a $0,3 \%$ ), logo após foram submetidos durante 10 minutos a 3 lavagens em solução de Krebs e mantidos, por um período de 60 minutos, no seguinte meio de incubação: $25 \mathrm{ml}$ de solução estoque de $\mathrm{NBT}^{5}$ (solução estoque na concentração de $0,000125 \mathrm{mg} / \mathrm{ml}), 25 \mathrm{ml}$ de tampão fosfato de sódio $^{6}(0,1 \mathrm{M})$, $50 \mathrm{ml}$ de água destilada e $0,05 \mathrm{~g}$ de $\beta-\mathrm{NADH}-\mathrm{d}^{5}$ (GABELLA, 1969).

A reação foi interrompida com a imersão dos espécimes em solução de formol a $10 \%$ em solução tampão fosfato (PBS: $0,1 \mathrm{M} ; \mathrm{pH} 7,4$ ). Preparados totais de membrana da parede posterior das traquéias e brônquios foram obtidos submetendo-se os espécimes à microdissecção das camadas mucosa e submucosa sob microscópio estereoscópico com transiluminação ${ }^{7}$ e material oftalmológico apropriado (pinças e tesouras). Os preparados totais de membrana assim obtidos foram montados entre lâmina e lamínula, em meio à glicerina tamponada.

\footnotetext{
${ }^{4} 1,3 \mathrm{~g}$ de $\mathrm{NaHCO}_{3}, 0,24 \mathrm{~g}$ de $\mathrm{MgCl}_{2} 6 \mathrm{H}_{2} \mathrm{O}, 0,44 \mathrm{~g}$ de $\mathrm{KCl}, 0,165 \mathrm{~g}$ de $\mathrm{NaH}_{2} \mathrm{PO}_{2}, 7,05 \mathrm{~g}$ de $\mathrm{NaCl}$ e $0,27 \mathrm{~g}$ de $\mathrm{CaCl}_{2}$ em 1 litro de água destilada.

${ }^{5}$ Sigma-Aldrich.

${ }^{6}$ Sinth®BRA.

${ }^{7}$ Carl Zeiss Microimaging modelo Stemi SV6, Göttingen, Alemanha. Laboratório de Anatomia Funcional Aplicada à Clínica e Cirurgia - LAFACC.
} 


\subsection{Técnica histoquímica da Nicotinamida Adenina Dinucleotídeo Fosfato diaforase - NADPH-d}

Cinco animais de cada grupo ( $N, D$ e $R$ ) foram utilizados para essa técnica. Inicialmente foram ligados com fios de algodão os brônquios principais, a fim de se injetar na luz da traquéia quantidade suficiente de PBS $(\mathrm{pH} 7,4)$. Após a ligadura da extremidade laríngea, as traquéias foram imersas por um período de 30 minutos em solução fixadora de paraformoldeído a 4\% em PBS e em seguida, mantidas por 10 minutos em solução de $0,3 \%$ de Triton $\mathrm{X}-100^{8}$ em PBS. Após 3 lavagens em PBS durante 10 minutos, os espécimes foram imersos por um período de 2 horas, no seguinte meio de incubação para a evidenciação neuronal da NADPH-d: $8 \mathrm{mg}$ de $\mathrm{NBT}^{9}, 70 \mathrm{mg}$ de $\beta$-NADPH ${ }^{9}$, em $100 \mathrm{ml}$ PBS (ALBUQUERQUE JÚNIOR, 2008) à $37^{\circ} \mathrm{C}$. Findo o período de incubação, realizou-se uma incisão longitudinal mediana na face ventral das traquéias que foram lavadas por 3 vezes em PBS durante 5 minutos cada e em seguida, mantidas em solução fixadora de paraformoldeído a $4 \%$ em PBS. Após a fixação, as traquéias foram dissecadas e montadas entre lâmina e lamínula como preparados totais de membrana, conforme descrito no item anterior.

\subsection{Técnica histoquímica da Acetilcolinesterase - AChE}

Para a evidenciação da reatividade dos neurônios à AChE (KARNOWSKY; ROOTS, 1964; MIZUNO et al., 2007) foram utilizados cinco animais de cada grupo (N, D e R). Após a ligadura dos brônquios, a luz da traquéia foi preenchida com solução de paraformoldeído a 4\% em PBS, permanecendo na mesma solução fixadora por um período de 1 hora a $4{ }^{\circ} \mathrm{C}$. Posteriormente as traquéias foram lavadas durante 12 horas em solução de

\footnotetext{
${ }^{8}$ Sigma-Aldrich.
} 
Krebs $(\mathrm{pH} 6,0)$ contendo hialuronidase ${ }^{9}$ e tetra-isopropil pirofosforamida (isoOMPA) ${ }^{8}$,para inibir as colinesterases inespecíficas (MABE; HOOVER, 2009).

A incubação foi realizada por um período de 18 a 24 horas a $4{ }^{\circ} \mathrm{C}$ sob agitação, em um meio contendo $0,075 \mathrm{mg}$ de acetilcolina ${ }^{8}, 97,5 \mathrm{ml}$ de PBS $(\mathrm{pH}$ 6,0), 7,5 ml de citrato de sódio (100mM), $15 \mathrm{ml}$ de sulfato de cobre (30mM), 15 $\mathrm{ml}$ de água destilada e $15 \mathrm{ml}$ de ferricianeto de potássio $(5 \mathrm{mM})$, acrescentandose quantidade equivalente de solução contendo hialuronidase ${ }^{10} \mathrm{e}$ iso-OMPA ${ }^{11}$.

Após o período de incubação, foram obtidos preparados totais de membrana como previamente descrito (itens 3.3 e 3.4), que foram desidratados em alcoóis de gradação crescente a começar de $70^{\circ}$ até passagem por 4 vezes em álcool absoluto durante cinco minutos em cada fase. Após diafanizados em xilol por 3 vezes durante três minutos, os espécimes foram montados entre lâmina e lamínula com resina Entellan ${ }^{12}$.

\subsection{Técnica imuno-histoquímica para Substância P (SP) e Peptídeo Intestinal Vasoativo (VIP)}

Os procedimentos para a evidenciação da imunorreatividade dos elementos do plexo traqueal à SP e ao VIP foram realizados em cortes semisseriados de $10 \mu \mathrm{m}$ de espessura da traquéia de 3 animais de cada grupo (N, D e R), de acordo com protocolo adaptado de Eustáquio-Silva (2010).

Os espécimes foram fixados em uma base de cortiça utilizando-se meio de inclusão apropriado para criossecção ${ }^{13}$. A fixação foi realizada de tal modo que o longo eixo da traquéia ficou perpendicular ao plano da base, a fim de ser submetido a cortes transversais. Os espécimes assim preparados foram mantidos durante 30 minutos em câmara de um criostato ${ }^{14}$ a uma temperatura de $-25^{\circ} \mathrm{C}$, com a finalidade de permitir a solidificação do meio de inclusão.

\footnotetext{
${ }^{9} 2000$ UTR Aspen.

102000 UTR Aspen.

${ }^{11}$ Sigma-Aldrich.

${ }^{12}$ Merck, Darmstadt, Alemanha.

${ }^{13}$ Killik, EasyPath (EP-51-20081).

${ }^{14}$ Leica Microsystems, Germany (CM 1850).
} 
Durante um período de 10 minutos, as lâminas foram lavadas por três vezes com uma solução de PBS ( $\mathrm{pH}$ 7.3) e em seguida incubadas, em câmara úmida, em soro de cabra ${ }^{15}$ a $10 \%$, por um período de duas horas. A incubação com os anticorpos primários anti $\mathrm{VIP}^{15}$ ou anti $\mathrm{SP}^{15}$, na proporção de 1:200, procedeu-se por um período de 24 horas a $4{ }^{\circ} \mathrm{C}$. Após nova lavagem em PBS (três vezes consecutivas durante 10 minutos), as lâminas foram incubadas com anticorpo secundário ${ }^{15}$ durante 1 hora em câmara escura. As lâminas foram montadas com uma lamínula, tendo como agente de adesão o glicerol tamponado ${ }^{16}$, e mantidas a $4{ }^{\circ} \mathrm{C}$ e ao abrigo da luz, até o momento de sua análise.

\subsection{Técnica da Microscopia Eletrônica de Varredura - MEV}

Foram utilizados 3 animais de cada grupo (N, D e R) para a avaliação tridimensional do plexo traqueal. Os animais foram anestesiados com solução anestésica ${ }^{17}$ (combinado de cloridrato de tiletamina e clorodrato de zolazepam, na proporção de $0,8 \mathrm{ml} / \mathrm{kg}$ de peso corpóreo, i.m., dose anestésica), e perfundidos através do ventrículo esquerdo com solução de Karnowsky modificada ( $2 \%$ de paraformaldeido, $25 \%$ de glutaraldeido e tampão fosfato $2 \mathrm{M}$, $\mathrm{pH} 7,4)$.

Após a retirada das traquéias como descrito no item 3.2, os espécimes foram imersos na mesma solução fixadora por um período mínimo de 48 horas a $4{ }^{\circ} \mathrm{C}$ quando então foram lavados em PBS, envoltos em papel alumínio e colocados em recipiente metálico contendo nitrogênio líquido, para imediato congelamento. Fragmentos das traquéias foram obtidos procedendo-se à criofratura das mesmas, com instrumento apropriado (bastão metálico).

Os fragmentos do órgão assim obtidos foram pós-fixados por imersão, durante 2 horas, em uma solução aquosa de tetróxido de ósmio a 1\% seguindo-se à desidratação em série crescente de alcoóis, de $70 \%$ ao

\footnotetext{
15 Bachem - Península Laboratories, USA.

${ }^{16}$ Bachem - Península Laboratories, USA.

${ }^{17}$ Zoletil@ 50, Virbac®.
} 
absoluto, permanecendo neste último até serem submetidos ao ponto crítico ${ }^{18}$. Os fragmentos foram então devidamente fixados em bases metálicas apropriadas, metalizadas com íons de ouro ${ }^{19}$ e analisados em um microscópio eletrônico de varredura ${ }^{20}$.

\subsection{Análise quantitativa}

A densidade e o número estimado de gânglios e neurônios do plexo traqueal, bem como a determinação da área do perfil celular dos neurônios ganglionares foram efetuados sob microscopia de luz, nos preparados de membrana submetidos às técnicas da NADH-d e NADPH-d. Para tanto, foram empregados métodos morfométricos estabelecidos de acordo com a amostra, conforme descrito por Mandarim-de-Lacerda (1995).

\subsection{Tratamento estatístico}

Os dados estão representados por média e desvio padrão. Os dados do peso corporal e peso traqueal foram submetidos a análise de variância (ANOVA) com 1 fator (grupo), comparando os grupos N, D e R. Os dados do número de neurônios, número de gânglios, número de neurônios por gânglio, área neuronal e área ganglionar foram submetidos a análise de variância com 2 fatores (grupo e região), com o objetivo de comparar os grupos do estudo e as regiões cervical e torácica da traquéia. Quando necessário prosseguiu-se a análise com comparações múltiplas pelo método de Tukey. A suposição de homogeneidade de variâncias foi verificada e quando necessário empregou-se transformação nos dados. Somente para a análise da razão peso

\footnotetext{
${ }_{18}^{18}$ BAL-TEC, modelo CPD-030, Schalksmühle, Alemanha. Departamento de Anatomia ICB/USP.

19 BALZERS, modelo SCD-040, Reinraumtechnik Lanz, Alemanha. Departamento de Anatomia ICB/USP.

${ }^{20}$ LEO, modelo 435 VP, Departamento de Anatomia dos Animais Domésticos e Silvestres da Faculdade de Medicina Veterinária e Zootecnia.
} 
traqueal/corporal foi utilizado o teste Kruskal-Wallis. Foi adotado como nível de significância $p<0,05$ (ZAR, 1984). 
4 RESULTADOS 


\subsection{Características gerais dos animais: ninhadas, monitoramento e aspectos macroscópicos}

Com a utilização do protocolo experimental anteriormente descrito e do monitoramento em gaiola metabólica foram notadas algumas diferenças físicas e comportamentais entre os grupos avaliados no presente experimento ( $\mathrm{N}, \mathrm{D}$ e R). Assim, as ninhadas dos animais $D$ eram mais numerosas que as do grupo $\mathrm{N}$, ou seja, enquanto as ninhadas do grupo $\mathrm{D}$ apresentavam de 12 a 17 filhotes, aquelas do grupo $\mathrm{N}$ variavam de 6 a 13 filhotes. Comparativamente aos filhotes do grupo $\mathrm{N}$, os do grupo $\mathrm{D}$ apresentaram o desenvolvimento tardio dos pelos, que eram uniformemente escasso, curto e menos vistoso, além de ser frequente a visualização de áreas com alopecia. Animais do grupo $\mathrm{N}$, por volta do $14^{\circ}$ dia de vida, mostravam-se bastante ativos e dispersos na caixa plástica, diferentemente do observado nos filhotes do grupo $D$, ficavam sempre agrupados e com comportamento apático.

Após o desmame, os animais foram monitorados individualmente em gaiola metabólica, e foi observado que, em determinados dias, os animais de todos os grupos mostravam-se ativos e reativos tentando escapar da manipulação ou, ao contrário ficavam hipoativos, letárgicos. Com relação aos animais do grupo $D$ não era difícil encontrá-los recolhidos no recipiente de ração da gaiola metabólica. Durante o monitoramento, alguns animais do grupo D manifestaram sudorese intensa, detectada pela presença de vapor na tampa superior da gaiola. Somente nas gaiolas dos animais do grupo $R$, no início do fornecimento da ração protéica, observou-se fezes pastosas, provavelmente decorrente da readaptação alimentar. Particularmente, os animais do grupo $\mathrm{N}$ dificilmente se encontravam hipoativos; ao contrário, mostravam-se reativos a manipulação, sempre atentos à movimentação na sala e, de certo modo, receptivos com relação ao manejo diário.

Quanto ao comprimento, os animais do grupo $\mathrm{R}$ assemelharam-se aos animais do grupo $\mathrm{N}$, e os animais do grupo $\mathrm{D}$ exibindo, praticamente, a metade do comprimento destes (Figura 4). 


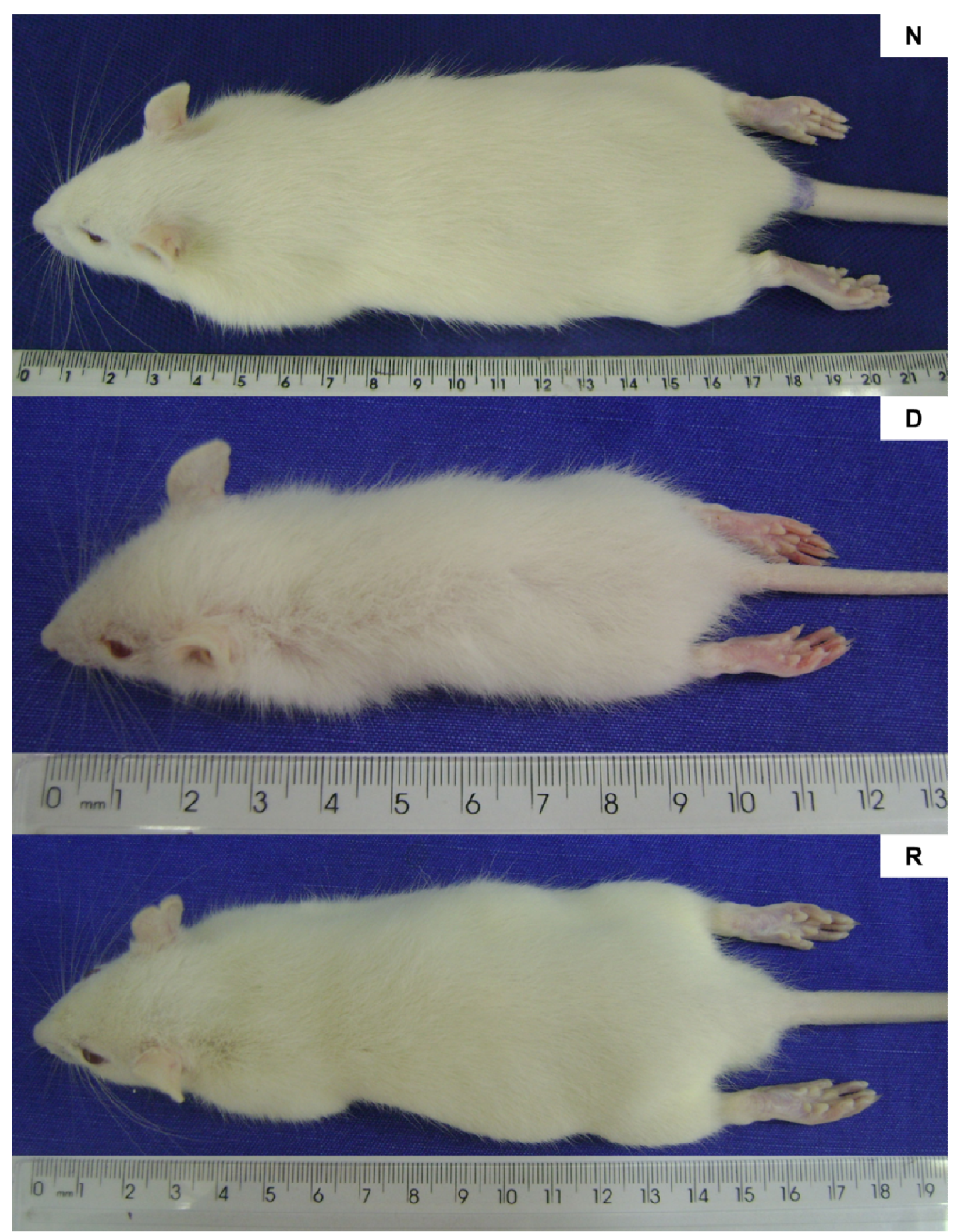

Figura 4 - Comprimento dos animais de todos os grupos (N, D e R).

Relativamente ao peso corporal, apesar da semelhança com os animais do grupo $\mathrm{N}$, o peso corpóreo dos animais do grupo $\mathrm{R}$ não alcançou o do grupo controle, e o peso dos animais do grupo $D$ ficou muito aquém do verificado para os outros dois grupos.

Dados sobre os parâmetros peso corporal, peso traqueal e razão peso traqueal/peso corporal estão expressos na tabela 1 e figuras 5-7. 
Tabela 1 - Média ( \pm DP) dos pesos corporal $(g)$ e traqueal $(g)$ e razão peso traqueal/peso corporal (\%) dos animais dos grupos N, D e R.

\begin{tabular}{lccc}
\hline \multicolumn{1}{c}{ Parâmetros } & Nutridos & Desnutridos & Renutridos \\
\hline & & & \\
Peso corporal & $153,94 \pm 21,20^{*}$ & $23,81 \pm 7,39^{*}$ & $100,92 \pm 23,86^{*}$ \\
Peso traqueal & $0,14 \pm 0,02^{*}$ & $0,03 \pm 0,02^{*}$ & $0,08 \pm 0,03^{*}$ \\
Peso traqueal/peso & $0,0009 \pm 0,0001$ & $0,0013 \pm 0,0006^{*}$ & $0,0007 \pm 0,0002$ \\
corporal & & & \\
\hline
\end{tabular}

${ }^{*} p<0,05$
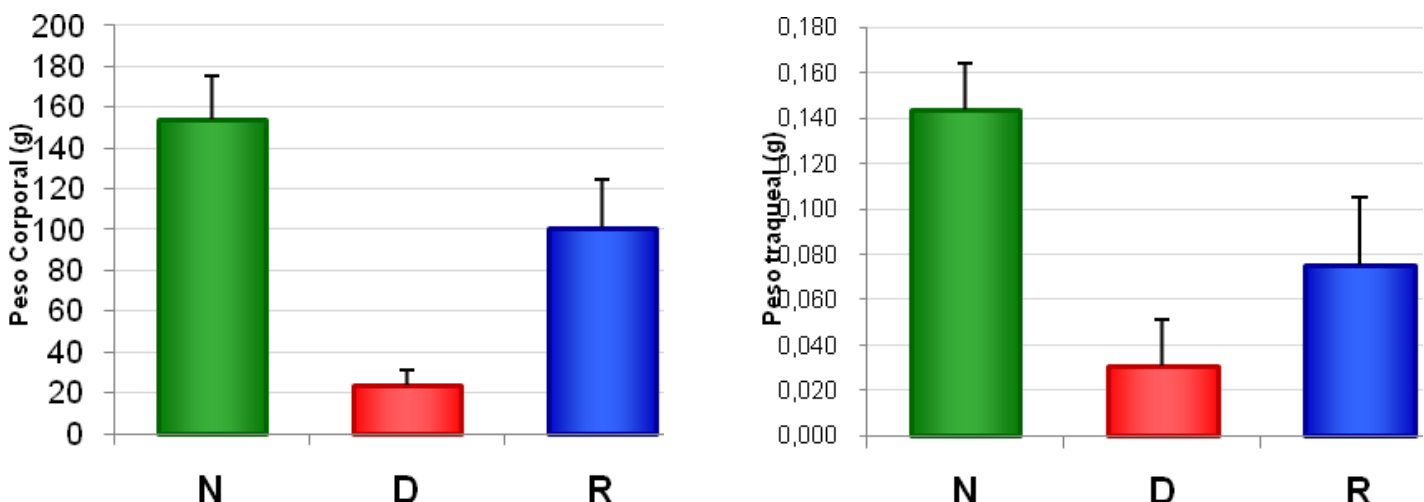

Figura 5 - Comparação gráfica do peso Figura 6 - Representação gráfica do peso corporal dos animais de todos os grupos (N, D e R) (g). traqueal dos animais de todos os grupos (N, D e R) (g).

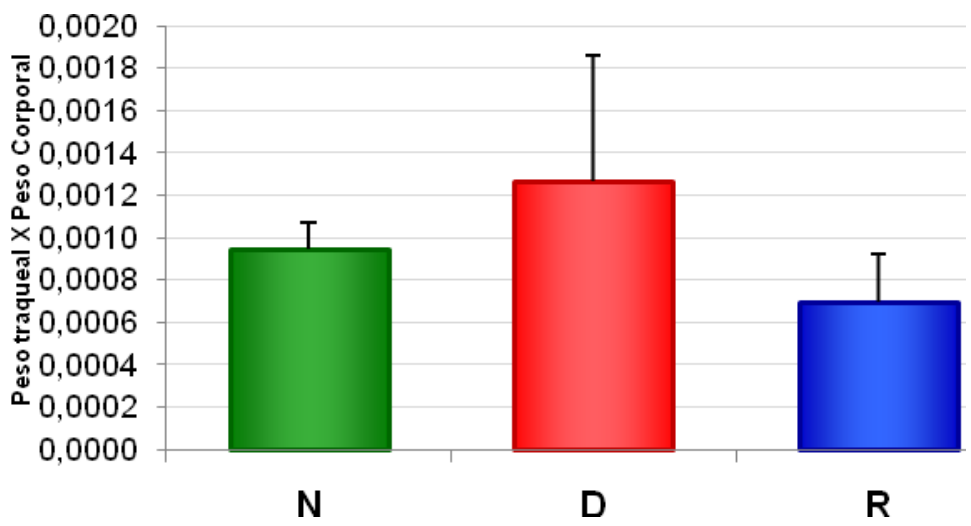

Figura 7 - Comparação gráfica da porcentagem de peso traqueal em razão ao peso corporal dos animais de todos os grupos (N, D e R) (\%). 
A análise dos dados permitiu verificar que os animais do grupo $D$ apresentaram o peso corporal muito menor que o obtido nos demais grupos e que, muito embora o peso corporal dos animais do grupo $R$ tenha se aproximado do grupo $\mathrm{N}$, após a análise estatística, foi identificado diferença significante entre estes ( $N$ e R) $(p<0,05)$, deste modo, pode-se identificar que os animais do grupo $\mathrm{N}$ são maiores que os animais dos grupos experimentais $\mathrm{e}$ que, entre os dois grupos experimentais ( $D$ e $R$ ), os animais do grupo $R$ são maiores que os do grupo $D(p<0,05)$. O peso traqueal seguiu o mesmo padrão de distribuição do peso corporal, onde o peso traqueal do grupo $\mathrm{N}$ é maior que os demais e que, entre os dois grupos experimentais, o grupo $\mathrm{R}$ é maior que $\mathrm{o}$ grupo $\mathrm{D}$, todavia a razão peso traqueal/peso corporal, expressa em porcentagem, foi maior nos animais dos grupos $\mathrm{D}$ e N, não diferindo entre si, sendo que os animais do grupo $R$ apresentaram a menor média $(p<0,05)$.

Durante o procedimento de retirada das traquéias, ao final dos 42 dias de tratamento, observou-se nos animais do grupo $D$ uma pele delgada e tecido adiposo subcutâneo praticamente ausente. A musculatura da região do abdome era translúcida, a ponto de permitir a visualização das vísceras a olho desarmado. Nesses animais, as costelas eram facilmente seccionadas durante o processo de abertura do tórax, comparativamente aos animais $\mathrm{N}$ e R.

A quantidade de tecido adiposo dos animais do grupo $\mathrm{N}$ depositado nas extremidades cervicais e torácicas da traquéia, particularmente nesta última, era maior que a verificada nos animais do grupo $R$; e nos animais do grupo $D$, era praticamente inexistente. Devido à natureza cartilagínea hialina dos anéis traqueais, as traquéias brilhantes dos animais dos grupos $\mathrm{N}$ e $\mathrm{R}$, com mucosa facilmente destacável, contrastavam com aquelas translúcidas e de mucosa fortemente aderida dos animais do grupo $D$. 


\subsection{Análise qualitativa}

\subsubsection{Características gerais do plexo traqueal}

Nos três grupos estudados (N, D e R), o plexo traqueal caracterizou-se por apresentar dois troncos principais ( $\mathrm{D}$ e E), que percorrem longitudinalmente a face posterior da musculatura traqueal, próximo à inserção desta com os anéis traqueais. A partir desses troncos, observam-se feixes nervosos de diferentes diâmetros (primários, secundários e terciários) que constituem uma malha sem orientação definida, disseminada sobre a superfície da musculatura traqueal. Prolongamentos terciários foram detectados, em alguns casos, entre os anéis traqueais.

Gânglios nervosos foram encontrados no tronco principal, nos feixes primários e secundários do plexo. Esses gânglios apresentam em seu interior, quantidade variável de neurônios, fazendo com que assumissem os mais diferentes formatos. Desta forma, foram verificados gânglios cuja quantidade de neurônios variou de 2 a 48. Relativamente, poucos neurônios isolados foram encontrados no interior de feixes nervosos (Figuras 8, 9, 10, 23). 


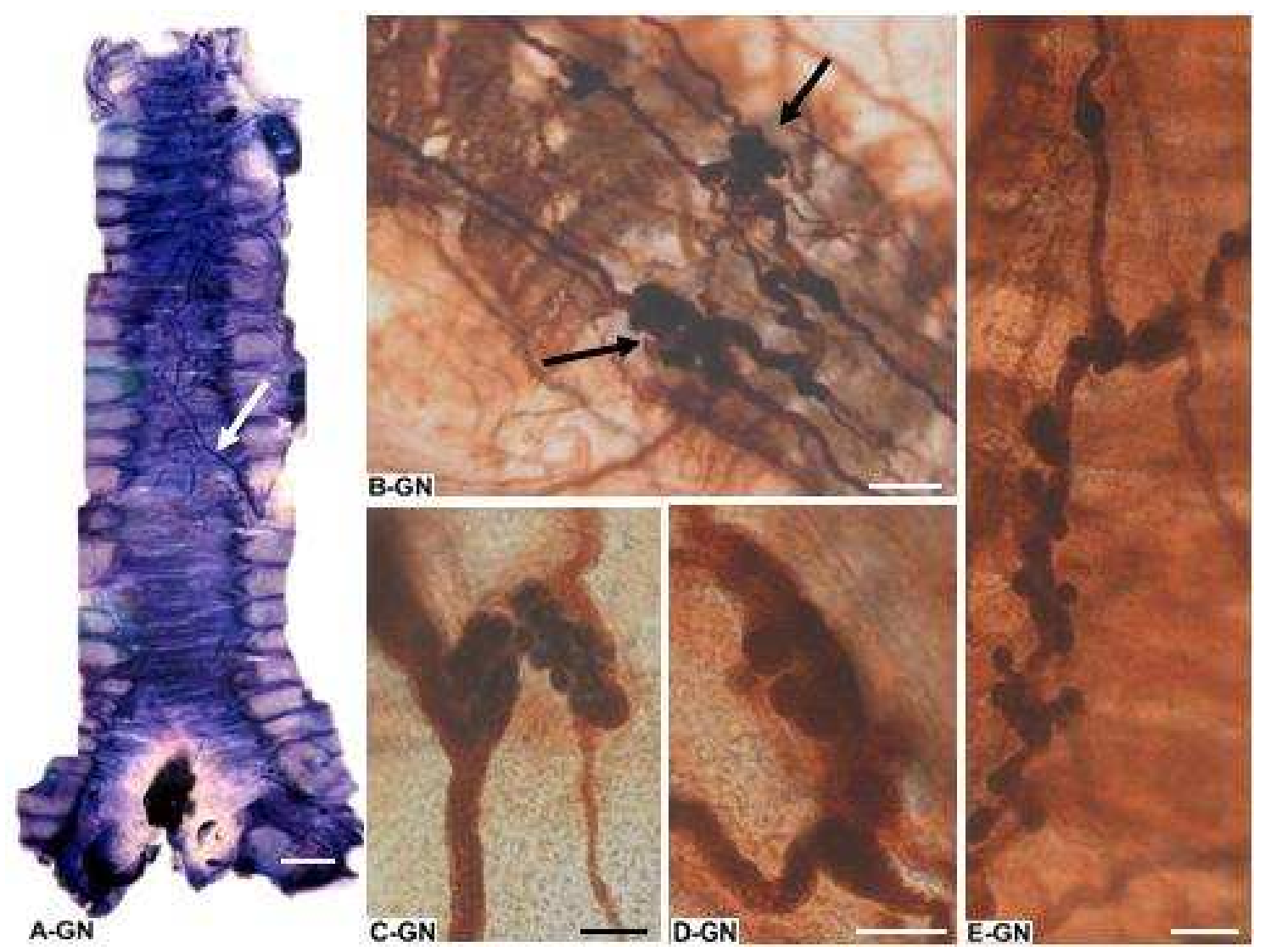

Figura 8 - Características gerais do plexo traqueal de ratos. A - Vista posterior da traquéia e dos brônquios principais. A seta indica o nervo laríngeo recorrente. B - Troncos longitudinais exibindo gânglios ao longo do seu trajeto (setas). C-E - Gânglios de diferentes formatos e tamanhos, com quantidade variável de neurônios. (A - NADH-d; B-E - AChE). (Barras de calibração: A - $500 \mu \mathrm{m}$; B, C, E - $100 \mu \mathrm{m}$; D - 50 m). 


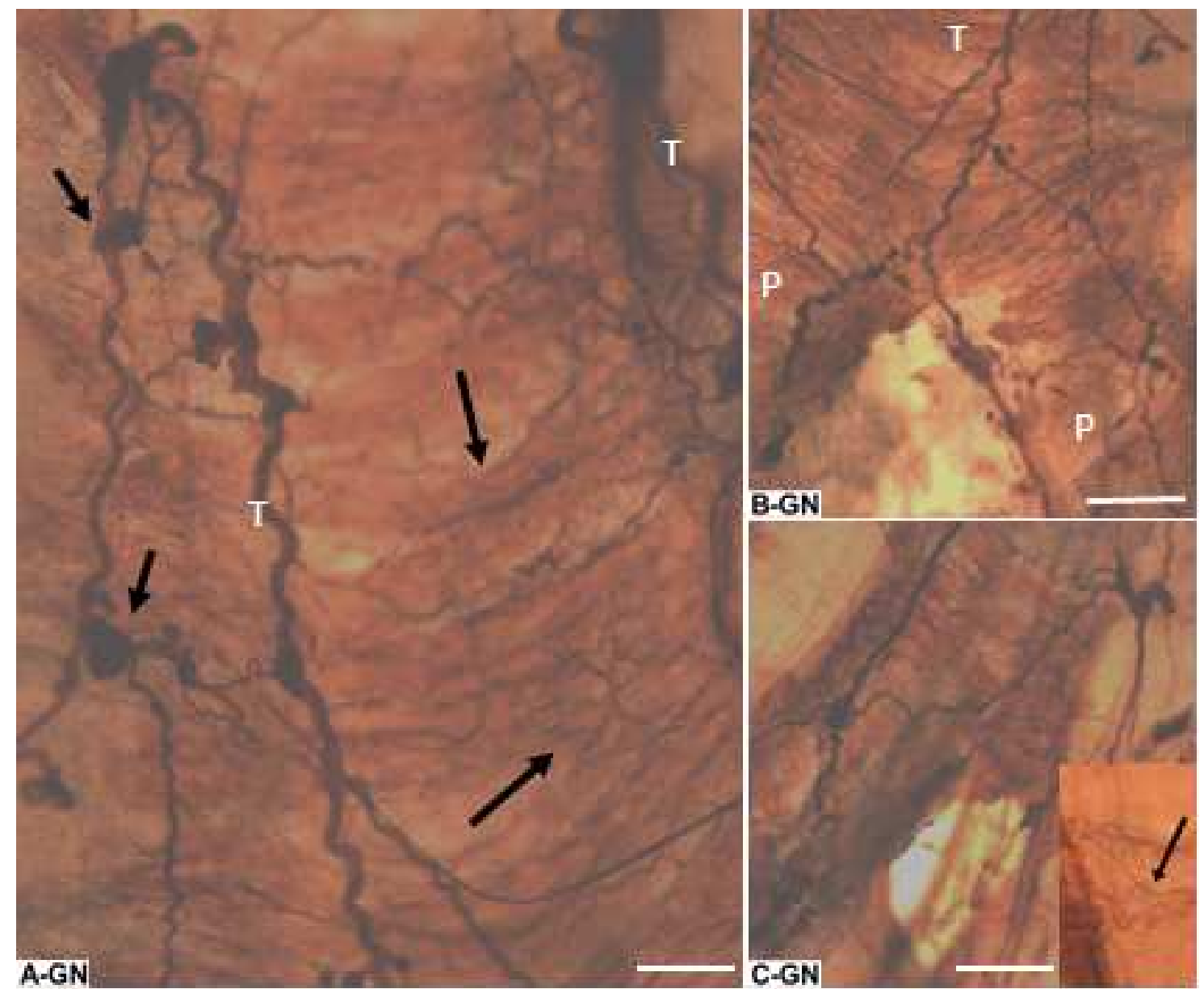

Figura 9 - Características gerais do plexo traqueal de ratos. A - Troncos nervosos principais $(T)$ de trajeto longitudinal cujas ramificações assumem direção oblíqua ou transversal em relação ao longo eixo da traquéia, formando uma rede de malhas irregulares (setas longas). Notar os gânglios dispostos ao longo dos feixes (setas curtas). B - Região de bifurcação da traquéia em brônquios principais onde se observa a continuidade dos feixes nervosos principais do plexo traqueal, bem como dos gânglios e da malha ( $T$ - traquéia; $P$ - brônquios principais). C - Continuidade da inervação nos brônquios lobares, com feixes e gânglios colinérgicos. No detalhe, fibras colinérgicas entre os anéis cartilagíneos (seta). (A-C AChE). (Barras de calibração: A-C - $200 \mu \mathrm{m}$ ). 

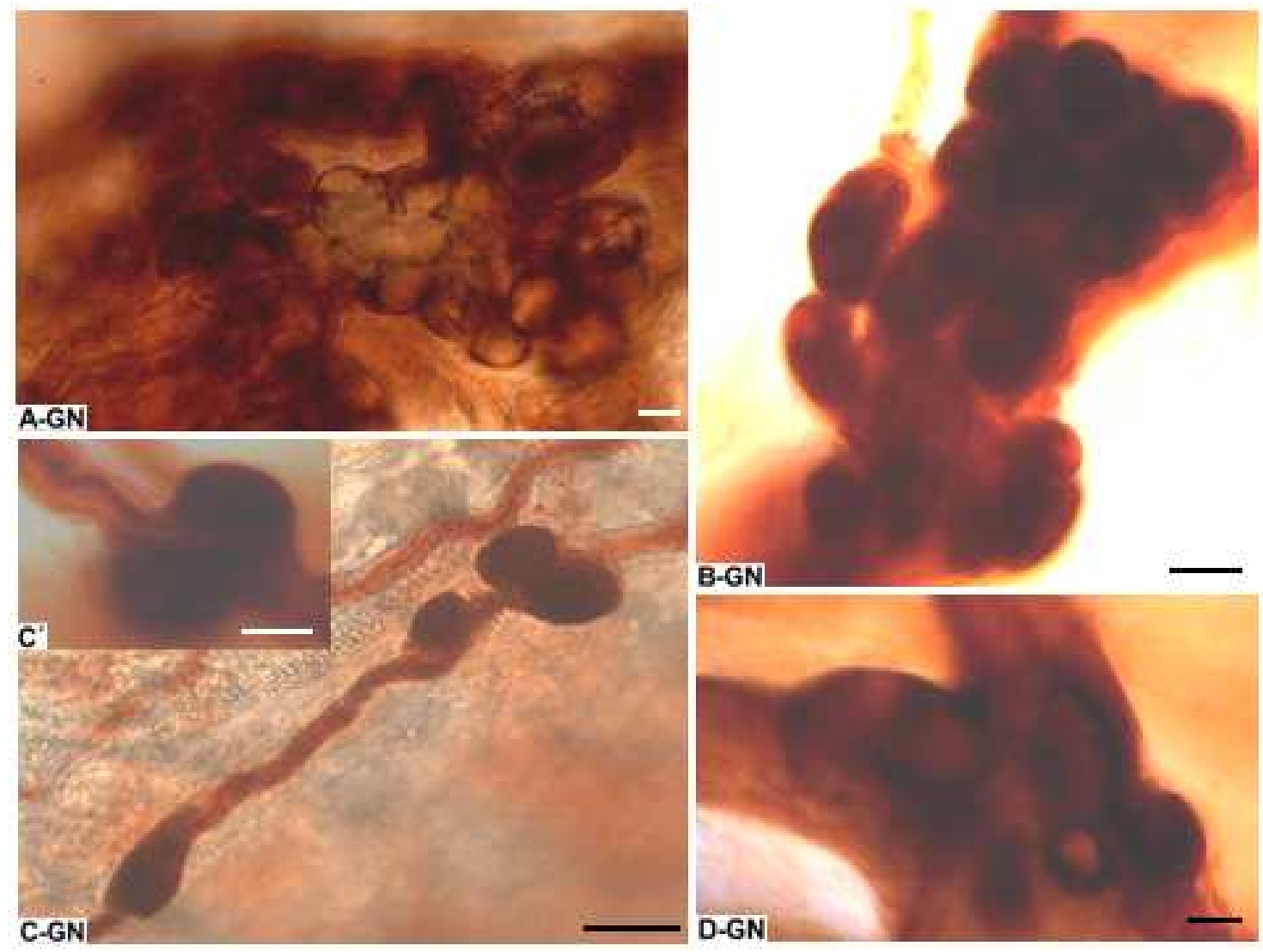

Figura 10 - Características gerais do plexo traqueal de ratos. A, B, D - Observar a variedade de formatos dos gânglios relativos à quantidade de neurônios no seu interior. C - Neurônios contidos no interior dos feixes nervosos. Observar, em destaque, dois neurônios e seus prolongamentos intensamente reativos. (A-D - AChE). (Barras de calibração: A, B, D, C' $20 \mu \mathrm{m}, \mathbf{C}-50 \mu \mathrm{m})$. 


\subsubsection{Morfologia dos gânglios e neurônios do plexo traqueal reativos à}

NADH-d

Através dessa técnica demonstrou-se que, além da grande variabilidade no formato dos gânglios, os neurônios ganglionares apresentaram diferentes tamanhos. Em todos os grupos (N, D e R), neurônios grandes, médios e pequenos foram detectados, não existindo diferenças entre os grupos estudados, relativamente a esse aspecto. Grande quantidade de células satélites também foi detectada através dessa metodologia no interior dos gânglios, que exibiram espaços amplos, somente nos animais do grupo D. 

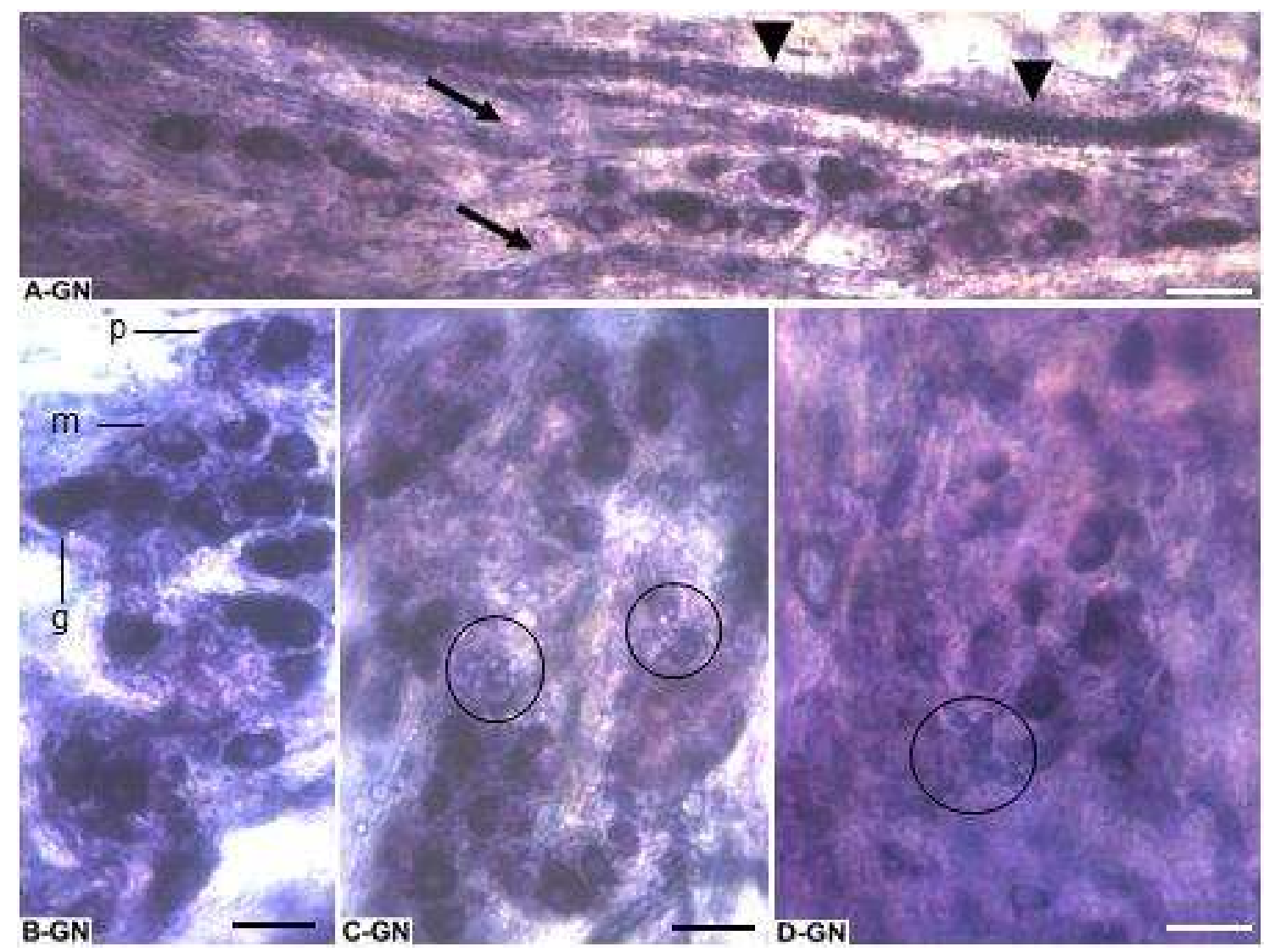

Figura 11 - Características gerais do plexo traqueal evidenciado pela técnica da NADH-d do Grupo N. A - Gânglio alongado constituído por duas fileiras de neurônios de diferentes tamanhos e formatos. Notar os feixes de fibras nervosas (setas) paralelas ao gânglio e um tronco nervoso principal (cabeças de seta). B - Gânglio contendo neurônios pequenos ( $p$ ), médios (m) e grandes (g). C, D - Gânglios arredondados com poucos neurônios e grande quantidade de células satélites preenchendo o espaço entre os neurônios (círculo). (Barras de calibração: A-D - $50 \mu \mathrm{m}$ ). 


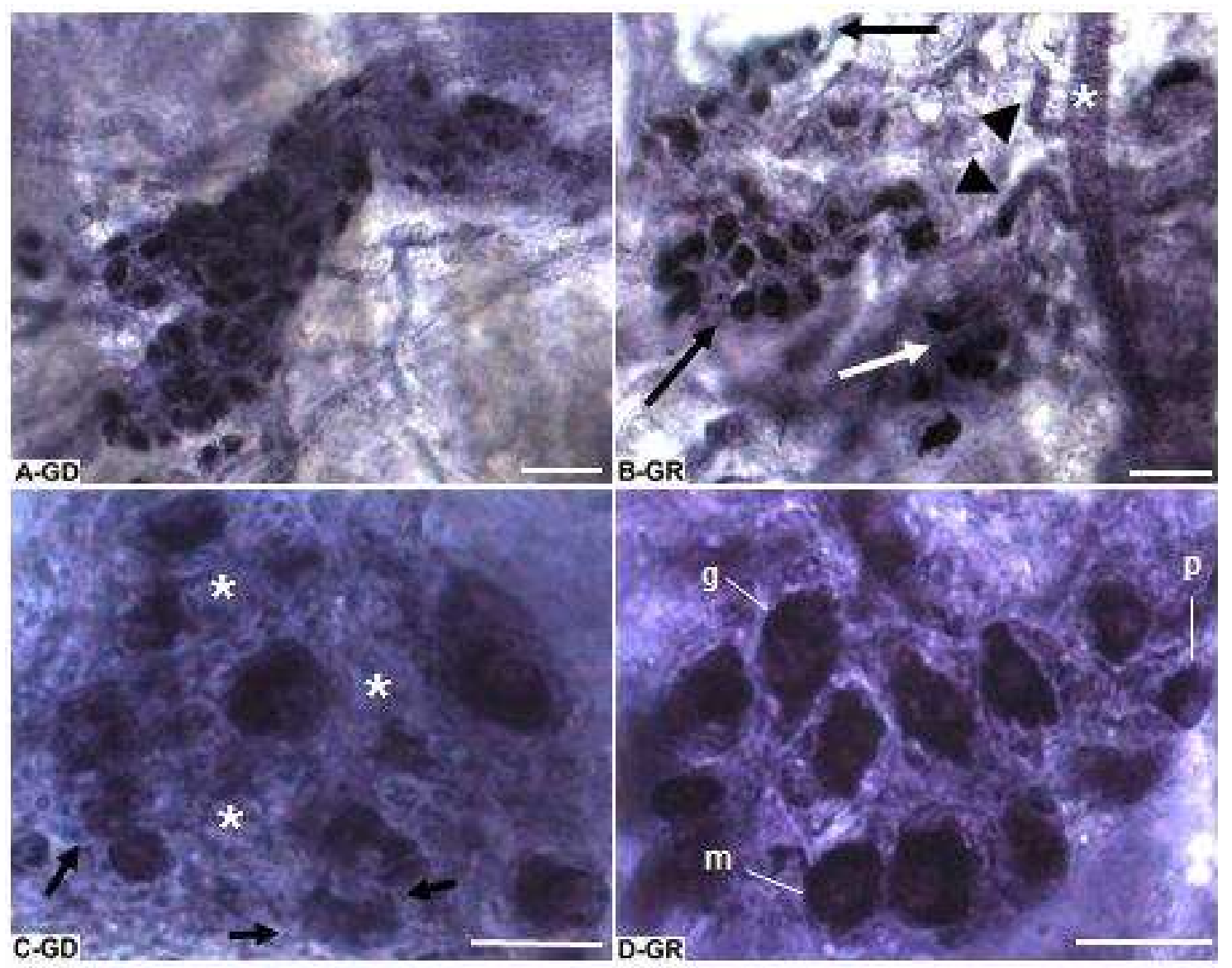

Figura 12 - Plexo traqueal evidenciado pela técnica da NADH-d dos grupos $D(A, C)$ e $R$ (B, D). A - Gânglio de tamanho grande contendo diversos neurônios. B Gânglios com formatos e tamanhos diferentes (setas). Notar os feixes de fibras destinados aos gânglios (cabeças de setas), partindo de um tronco nervoso principal ( $\left.{ }^{*}\right)$. C - Gânglio com amplos espaços $\left(^{*}\right)$ entre os neurônios de diferentes tamanhos. Notar a grande quantidade de neurônios pequenos (setas). D - Neurônios pequenos ( $p$ ), médios $(m)$ e grandes $(g)$ presentes no interior de um gânglio. (Barras de calibração: A-B - $50 \mu \mathrm{m}$; C-D - $20 \mu \mathrm{m}$ ). 


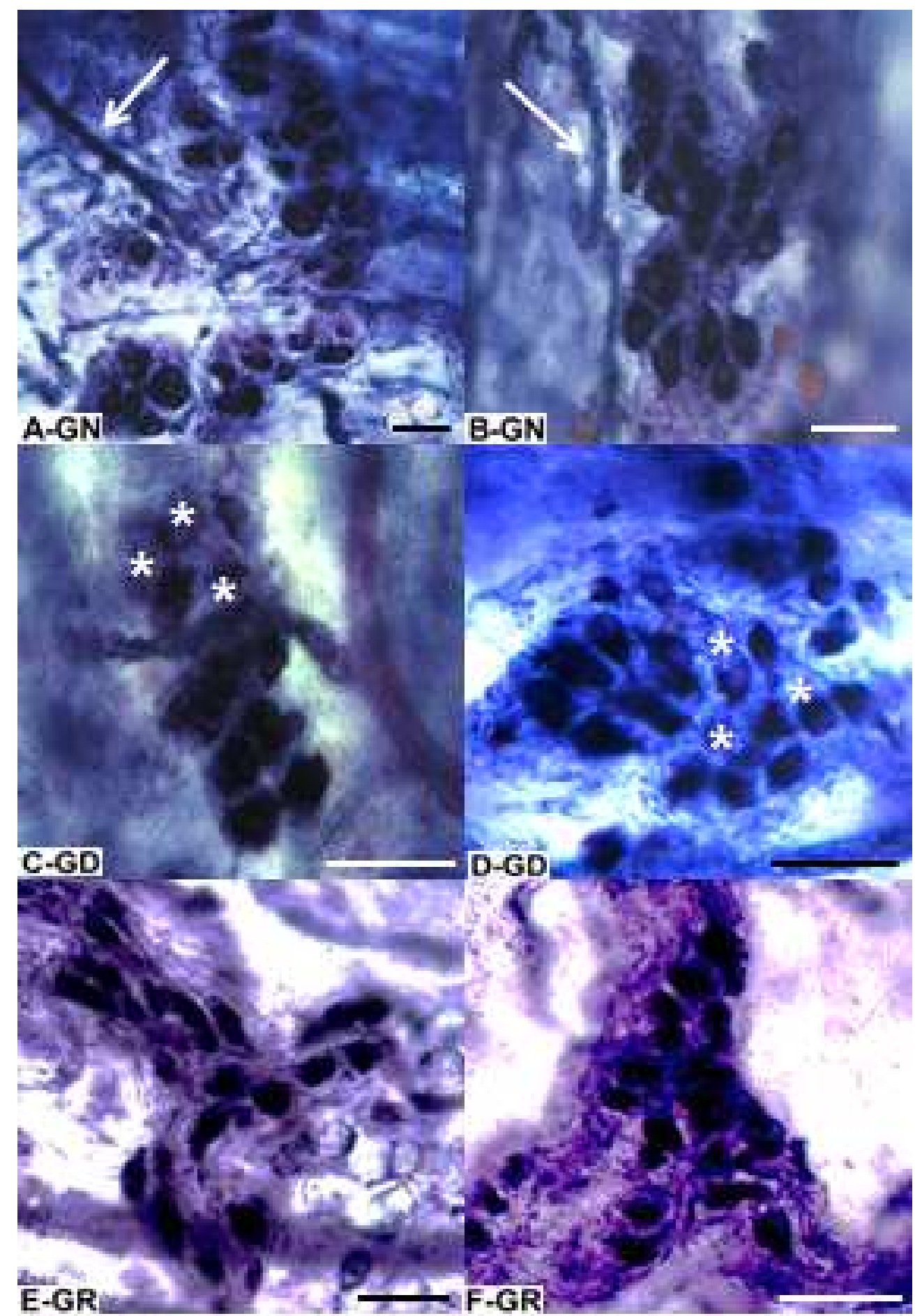

Figura 13 - Características gerais dos gânglios pertencentes ao plexo traqueal, evidenciados pela técnica NADH-d dos grupos N (A-B), D (C-D) e R (EF). A-F - Gânglios com diferentes tamanhos e formatos. A-B - Gânglios apresentando estreita relação com feixe nervoso (seta). C-D - Gânglios com espaços amplos no seu interior $\left(^{*}\right)$. E-F - Gânglios com formato irregular, com grande quantidade de neurônios no seu interior. (Barras de calibração: A-F - $50 \mu \mathrm{m})$. 


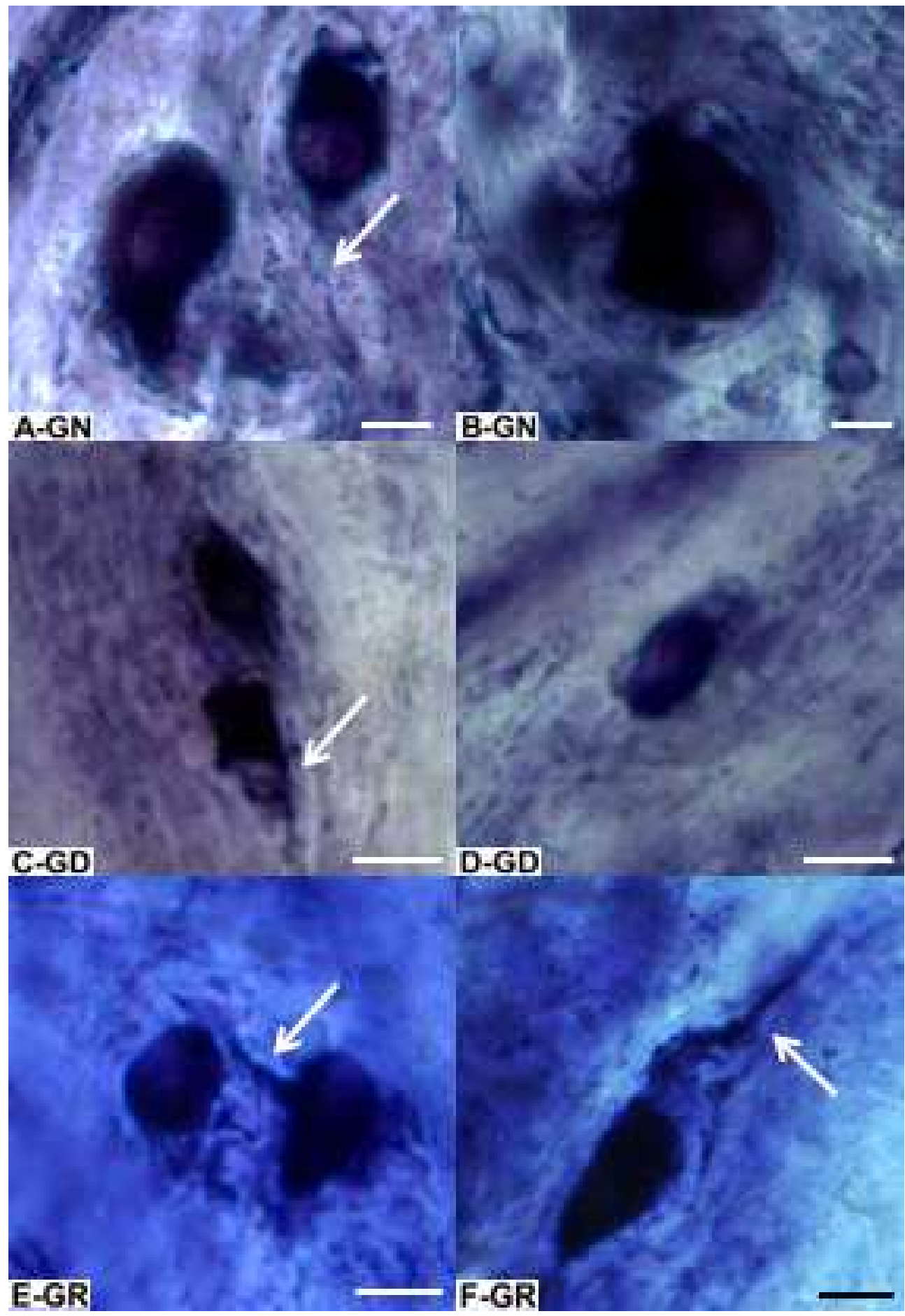

Figura 14 - Características gerais dos neurônios que compõe o plexo traqueal, evidenciados pela técnica NADH-d dos grupos N (A-B), D (C-D) e R (EF). A-F - Notar a variedade de formatos apresentado pelos neurônios de todos os grupos (N, D e R). Observar prolongamentos axonais em muitos neurônios (setas). (Barras de calibração: A-F - $10 \mu \mathrm{m}$ ). 


\subsubsection{Morfologia dos gânglios e neurônios do plexo traqueal reativos à NADPH-d}

Essa reação, utilizada para diferenciar neurônios nitrérgicos, permitiu identificar, principalmente, as diferentes intensidades de reação dessas células. Em todos os grupos estudados, foram detectados neurônios intensa ou fracamente reativos nos mais variados formatos de gânglios, não sendo possível determinar diferenças significantes entre os grupos (N, D e R).

Como característica comum aos três grupos ( $N$, D e R), deve-se ressaltar a presença de amplos espaços no interior dos gânglios, não necessariamente significando ausência de neurônios (Figuras 15-18). 


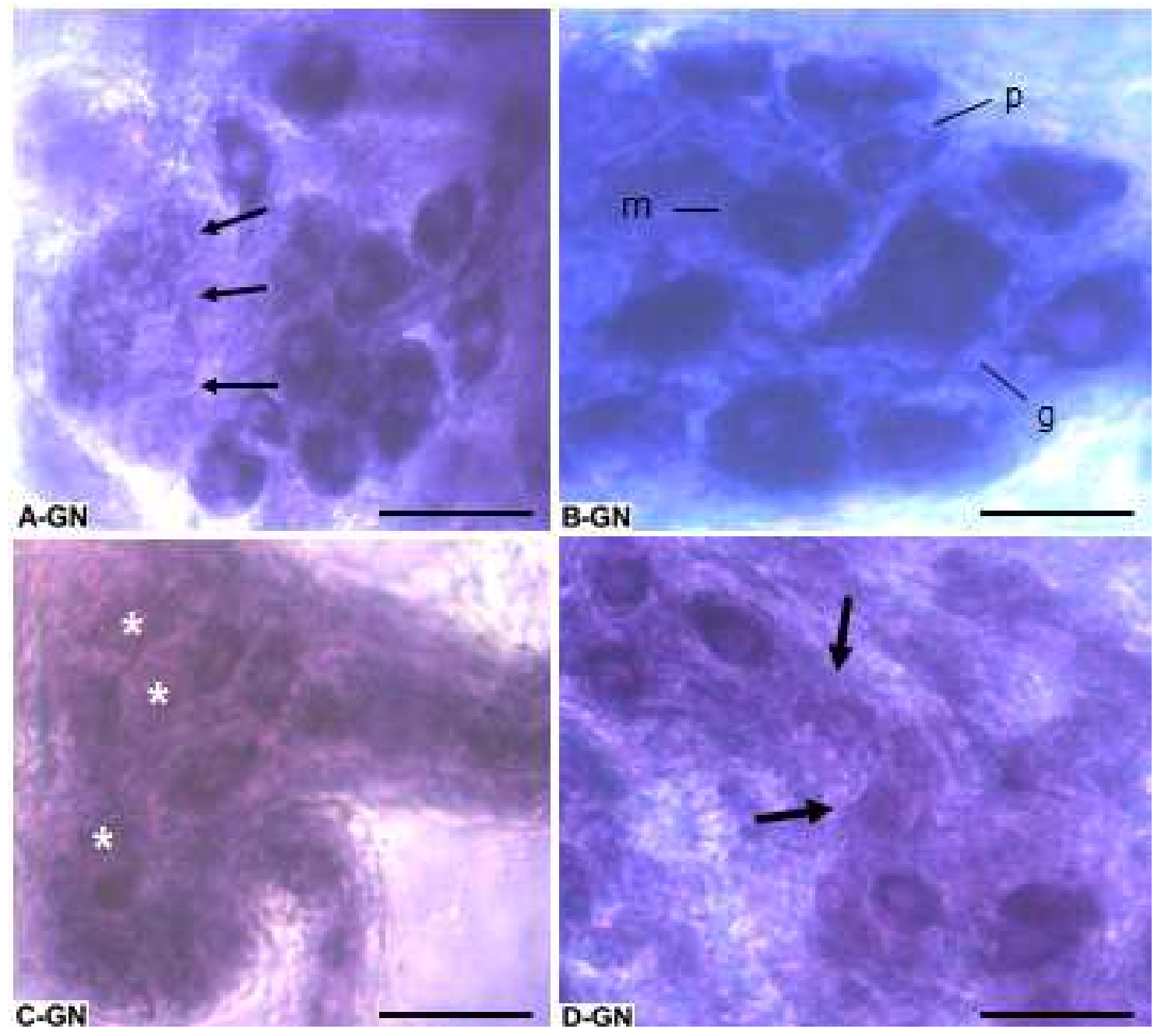

Figura 15 - Plexo traqueal evidenciado pela técnica da NADPH-d de animais do grupo N. A - Gânglio contendo neurônios de reatividade homogênea, destacando-se um agrupamento de células satélites (setas). B - Neurônios pequenos ( $p$ ), médios $(m)$ e grandes ( $g$ ). C - Gânglio com poucos neurônios reativos e espaços $\left({ }^{*}\right)$, provavelmente preenchidos por neurônios não nitrérgicos. D - Feixe nervoso interganglionar espesso, contendo neurônios fracamente reativos (setas). (Barras de calibração: $\mathbf{A}$, C, D - $50 \mu \mathrm{m}$; B - $20 \mu \mathrm{m}$ ). 


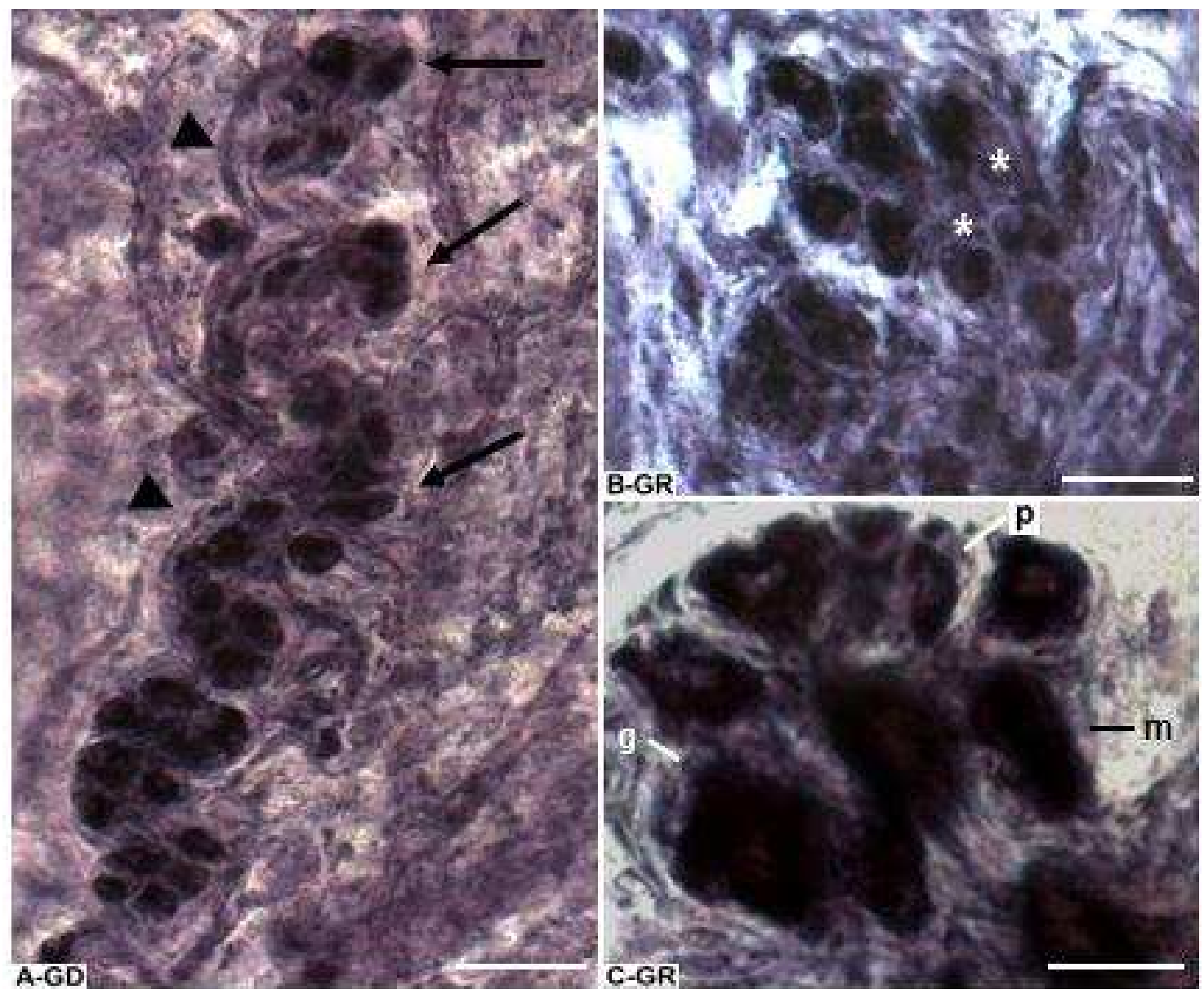

Figura 16 - Plexo traqueal evidenciado pela técnica da NADPH-d dos grupos $D(A)$ e $R$ (B-C). A - Gânglios de diferentes tamanhos (setas). Notar a inter-relação a partir de um feixe nervoso principal (cabeças de setas). B - Aspecto geral de um gânglio contendo poucos neurônios com reatividade relativamente homogênea e espaços no seu interior $\left({ }^{*}\right)$. C - Neurônios de diferentes formatos e tamanhos ( $\mathrm{p}, \mathrm{m}$ e $\mathrm{g}$ ). Notar que, independentemente do tamanho, a intensidade de marcação é aparentemente a mesma em todos os neurônios. (Barras de calibração: A, C - 50 m; B - $20 \mu \mathrm{m}$ ). 


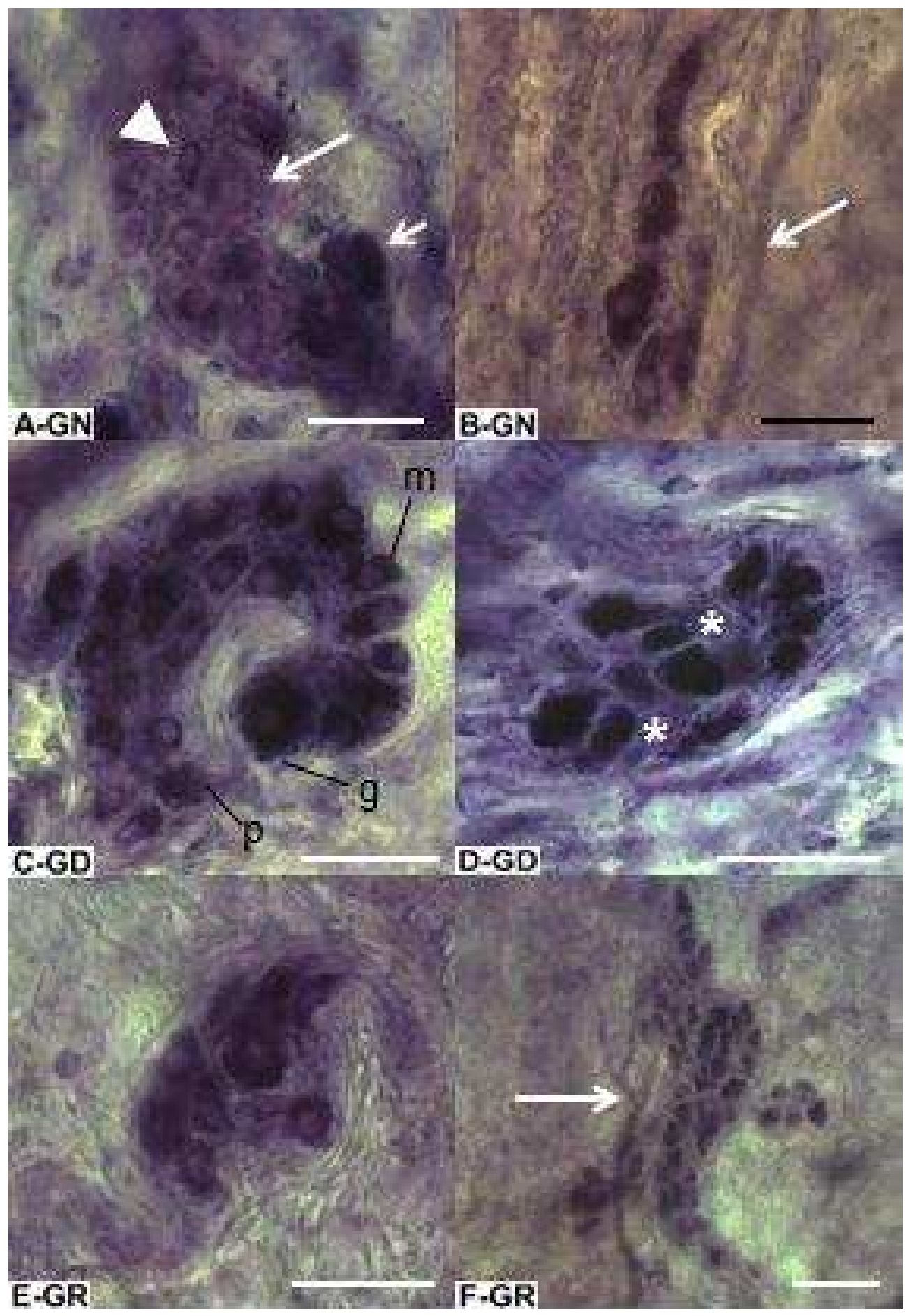


Figura 17 - Características gerais dos gânglios pertencentes ao plexo traqueal, evidenciados pela técnica NADPH-d dos grupos N (A-B), D (C-D) e R (EF). A-F - Diversos formatos e tamanhos dos gânglios de todos os grupos (N, D e R). A - Gânglios com grande quantidade de neurônios, contendo neurônios fortemente (seta curta), moderadamente (cabeça de seta) e fracamente reativos (seta longa). B - Gânglio alongado, paralelo a um feixe de fibra nervosa. C - Gânglio com formato espiral, constituído por neurônios pequenos (p), médios (m) e grandes (g). D - Gânglio apresentando amplos espaços $\left(^{*}\right)$ entre neurônios com variadas intensidades de marcação. E - Gânglio apresentando neurônios com reatividade homogênea. F - Gânglio com grande quantidade de neurônios, notar a presença de um feixe nervoso muito próximo. (Barras de calibração: A-E - $50 \mu \mathrm{m} ; \mathbf{F}$ - $100 \mu \mathrm{m}$ ). 


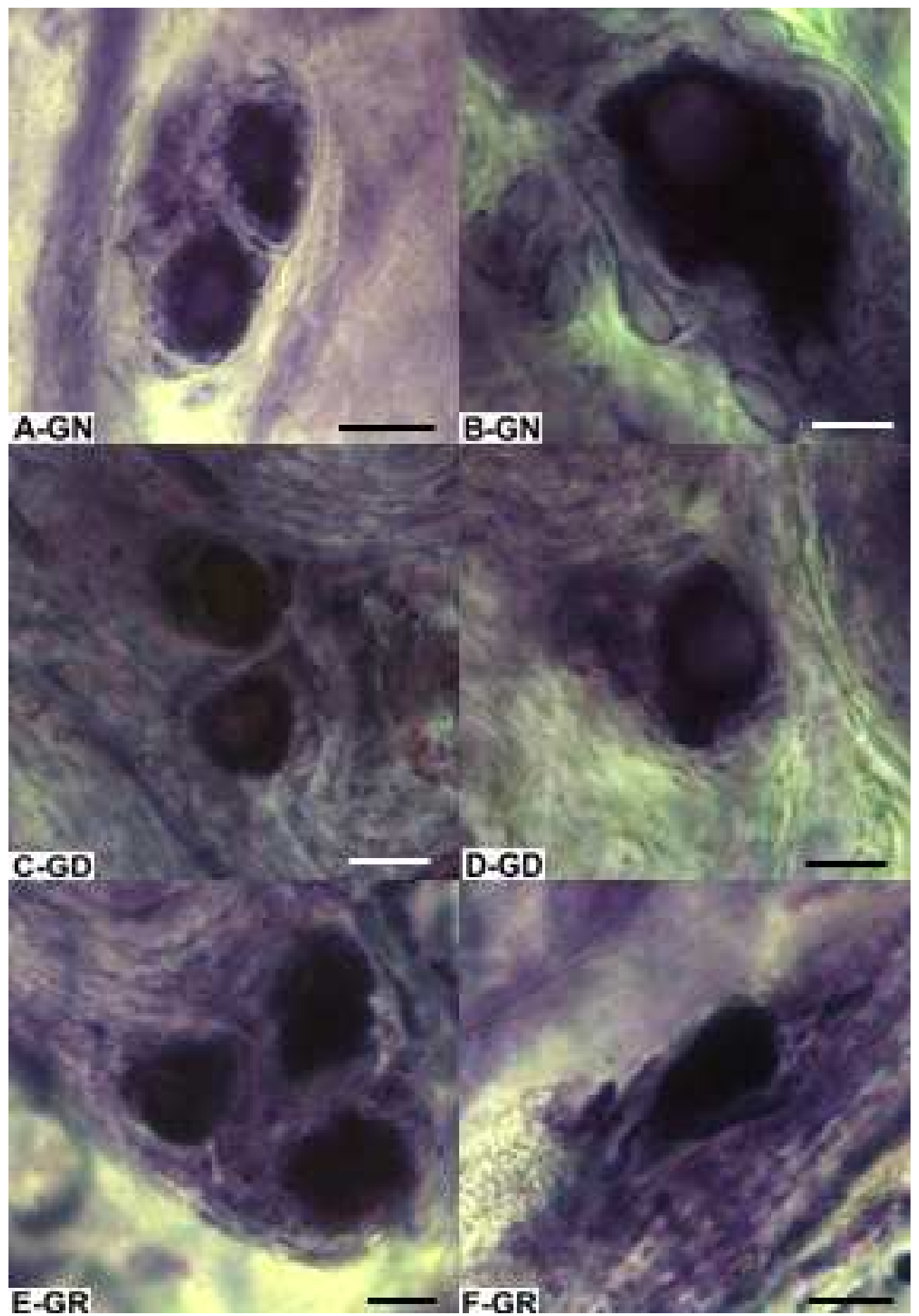

Figura 18 - Características gerais dos neurônios componentes do plexo traqueal, evidenciados pela técnica NADPH-d de todos os grupos N (A-B), D (C-D) e $R$ (E-F). A-F - Neurônios intensamente reativos, circundados por diversas células satélites. Notar a variedade de formatos apresentados pelos neurônios de todos os grupos (N, D e R). Observar neurônios com formato alongado, ovóide, circular. (Barras de calibração: A - $25 \mu \mathrm{m}$; B-F $-10 \mu \mathrm{m})$. 


\subsubsection{Morfologia dos gânglios e neurônios do plexo traqueal reativos à AChE}

A presença de feixes nervosos intensamente reativos mostrou-se um aspecto característico a todos os grupos analisados ( $N, D$ e R). Assim como observado com o uso das outras técnicas (NADH-d e NADPH-d), a morfologia dos gânglios exibiu grande variabilidade, relativamente ao número de neurônios contidos em seu interior.

Ao se avaliar a reatividade dos neurônios ganglionares à $A C h E$, verificou-se que, particularmente nos grupos $\mathrm{N}$ e $\mathrm{R}$, a grande maioria dessas células exibiu intensa reatividade, tendo sido detectados poucos neurônios com moderada ou fraca reatividade; de modo contrário, no grupo $D$, a maior quantidade de neurônios exibiu moderada reatividade ou apresentaram-se fracamente reativos (Figuras 19-21). 


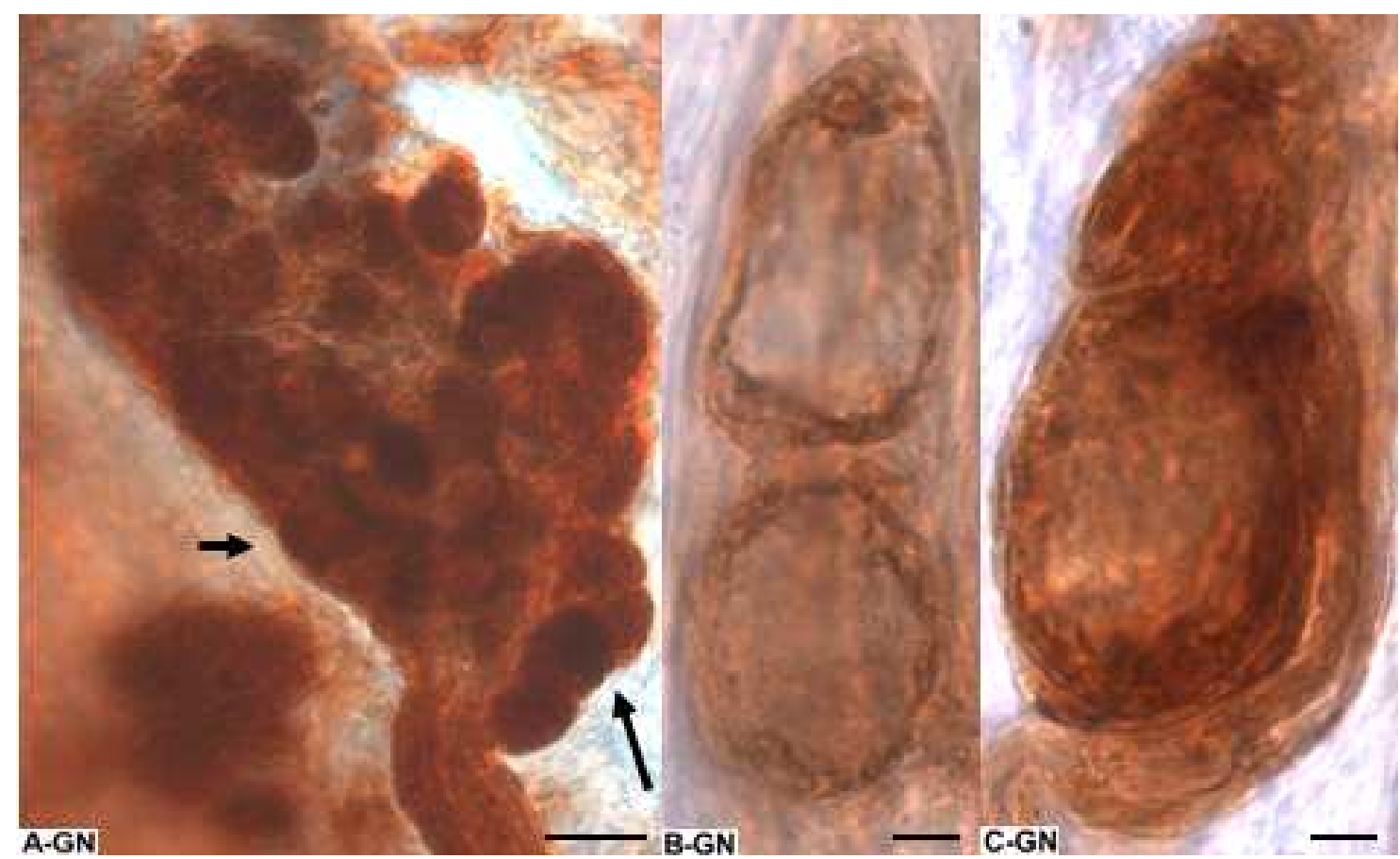

Figura 19 - Plexo traqueal evidenciado pela técnica da AChE de animais do grupo N. A - Gânglio com grande quantidade de neurônios exibindo reatividade intensa (seta longa) ou moderada (seta curta). B - Neurônios com citoplasma fracamente reativo. Comparar com o neurônio da figura $\mathbf{C}$, intensamente reativo. (Barras de calibração: A - $50 \mu \mathrm{m}$; B-C - $5 \mu \mathrm{m}$ ). 


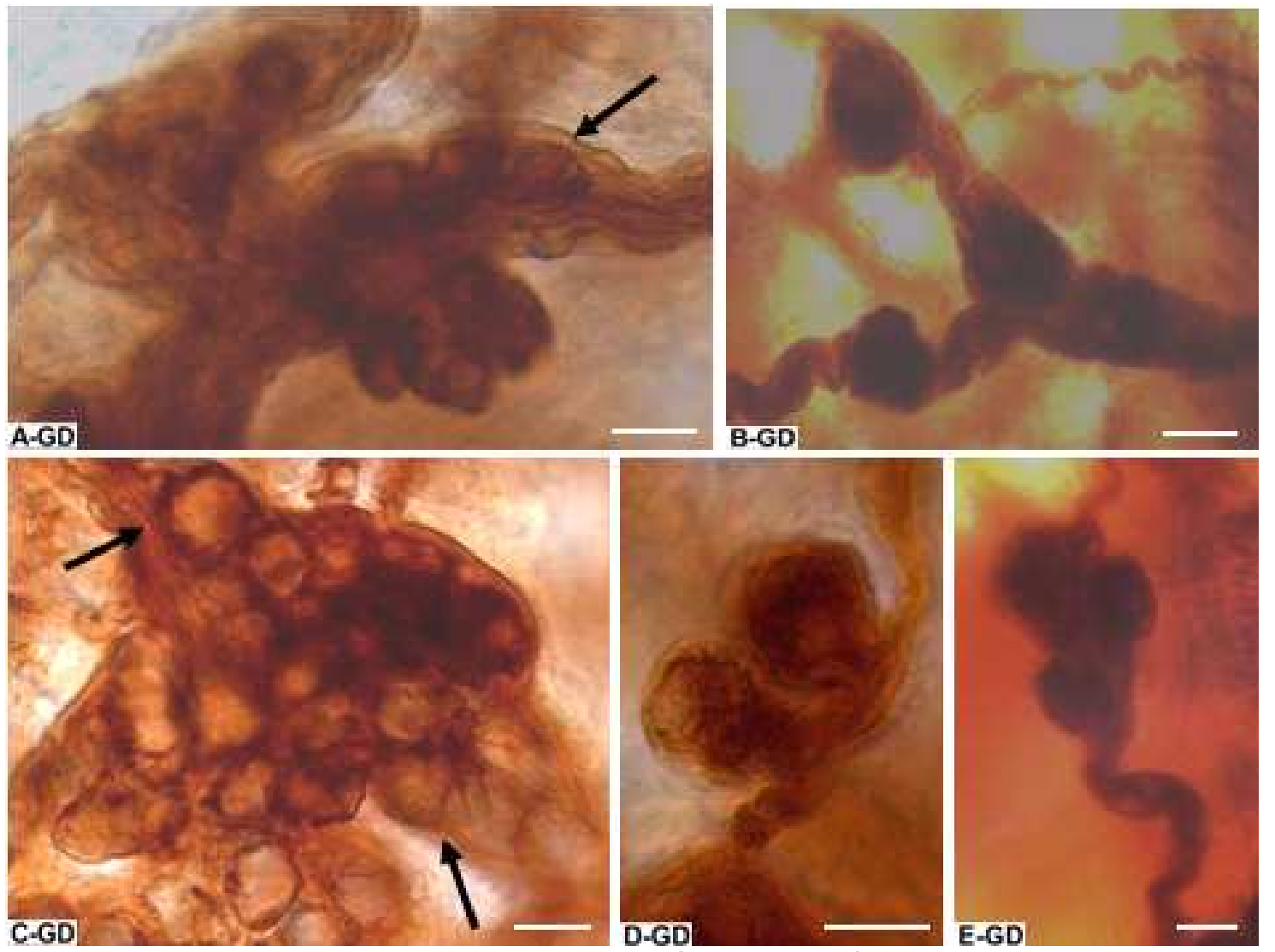

Figura 20 - Plexo traqueal evidenciado pela técnica da AChE de animais do grupo D. A, C - Gânglios com grande quantidade de neurônios, muitos deles exibindo fraca reatividade (setas). B, E - Neurônios intensamente reativos observados no interior dos feixes nervosos. D - Gânglio com apenas dois neurônios, exibindo fraca reatividade. (Barras de calibração: A-E - $20 \mu \mathrm{m}$ ). 


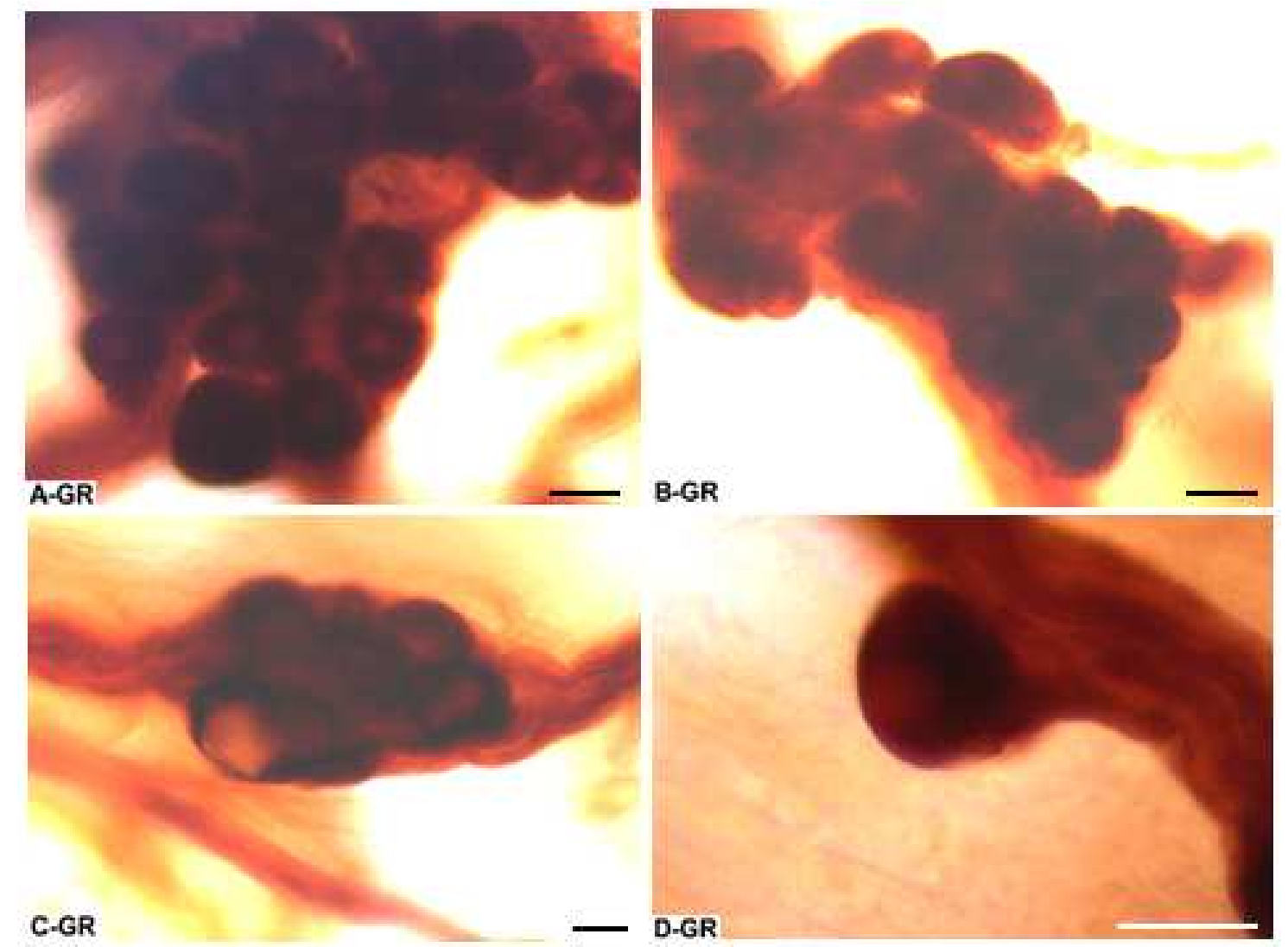

Figura 21 - Plexo traqueal evidenciado pela técnica da AChE de animais do grupo $R$. A, B - Gânglios com grande quantidade de neurônios intensamente reativos. C - Gânglio pequeno, contendo neurônios intensamente reativos. D - Neurônio intensamente reativos contido no interior de um feixe nervoso. (Barras de calibração: A-D - $20 \mu \mathrm{m}$ ). 


\subsubsection{Morfologia dos neurônios do plexo traqueal reativos à SP e ao VIP}

A figura 22 demonstra aspectos comparativos do plexo traqueal entre os grupos N, D e R, evidenciados pelas técnicas imuno-histoquímicas da SP e do VIP. Analisando as duas técnicas conjuntamente, de um modo geral, poucos neurônios, em todos os grupos, demonstraram intensa imunorreatividade, tanto para a SP quanto para o VIP. Ao se correlacionar a imunorreatividade com o tamanho dos neurônios, verificou-se que os poucos que se apresentaram intensamente imunorreativos, eram aqueles de tamanho pequeno, em todos os grupos analisados (N, D e R). 


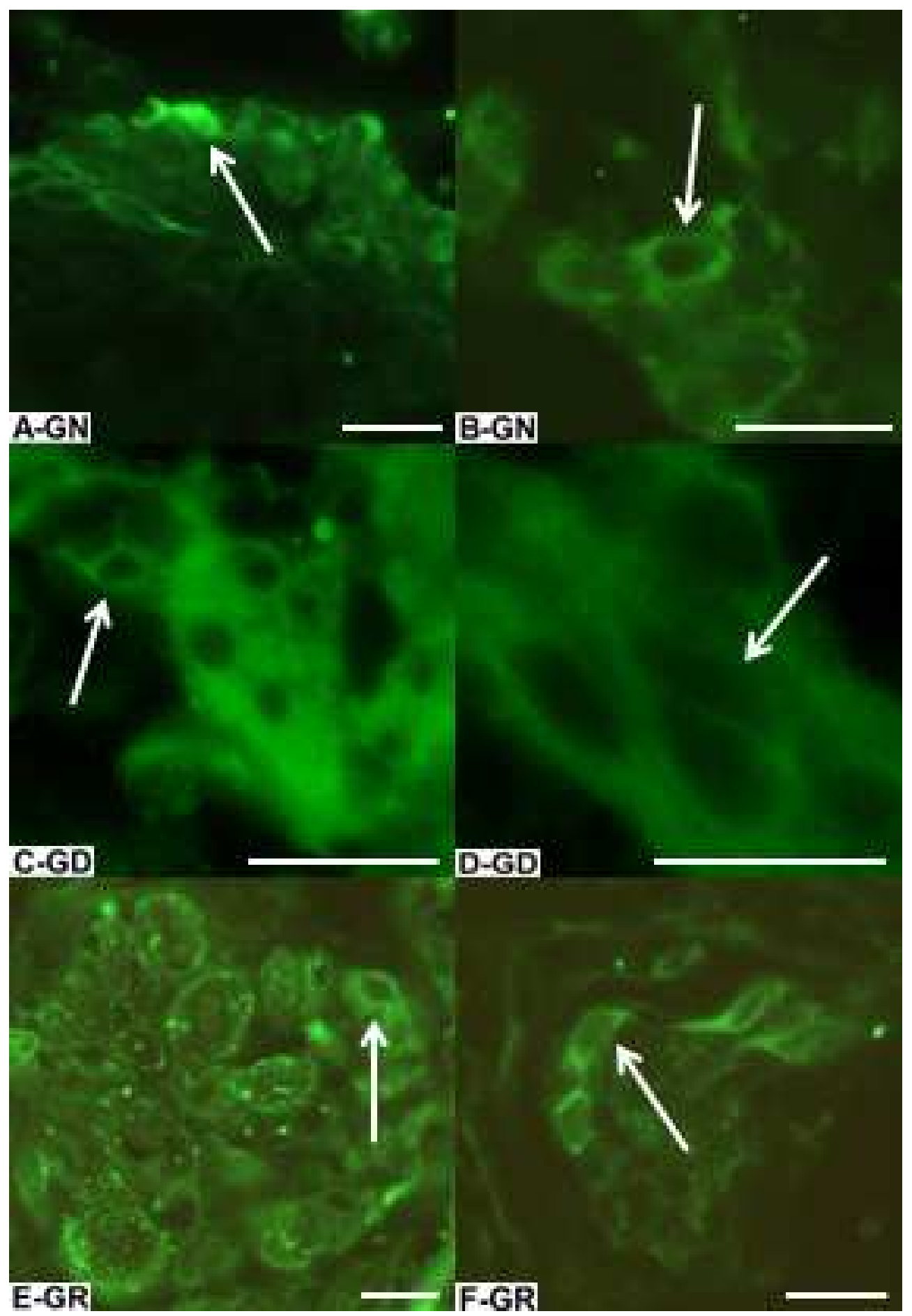

Figura 22 - Fotomicrografias exibindo a imunorreatividade do plexo traqueal à $S P(A, C$ e E) e ao VIP (B, D e F) dos grupos N (A-B), D (C-D) e R (E-F). Notar a variabilidade dos gânglios quanto ao tamanho e número de neurônios e a proporção pequena de neurônios exibindo intensa reatividade (setas), exceto em $\mathbf{D}$, onde os neurônios apresentaram-se fracamente reativos ou com nenhuma reatividade. (Barras de calibração: A-F - $20 \mu \mathrm{m}$ ). 


\subsubsection{MEV dos componentes do plexo traqueal}

Todas as características gerais descritas sobre os componentes do plexo traqueal no item 4.2.1 foram observadas sob o aspecto tridimensional, proporcionado pela MEV. Assim, inicialmente, os aspectos da malha do plexo, de aspecto pantográfico, foram confirmados sendo possível se visualizar, nitidamente, os feixes primários, secundários e terciários (Figura 23).

A morfologia dos gânglios descrita nas observações das preparações histoquímicas pode ser melhor avaliada sob MEV. Desta forma, constatou-se que os gânglios, anexados aos espessos feixes a malha primária, apresentavam corpos neuronais compactados em seu interior, formando pelo menos duas camadas (Figura 24).

Aos gânglios estão anexados feixes de fibras nervosas de pequeno diâmetro, provenientes das malhas terciárias, cujos prolongamentos podem ser observados distribuídos no interior do gânglio, entre os corpos neuronais (Figuras 25C, 27D).

Através dos diferentes métodos de corrosão empregados verificou-se a presença de uma cápsula ganglionar constituída por fibrilas colágenas que, à maneira de uma rede, contém os corpos neuronais de tamanhos pequeno, médio e grande (Figuras 26, 27). 

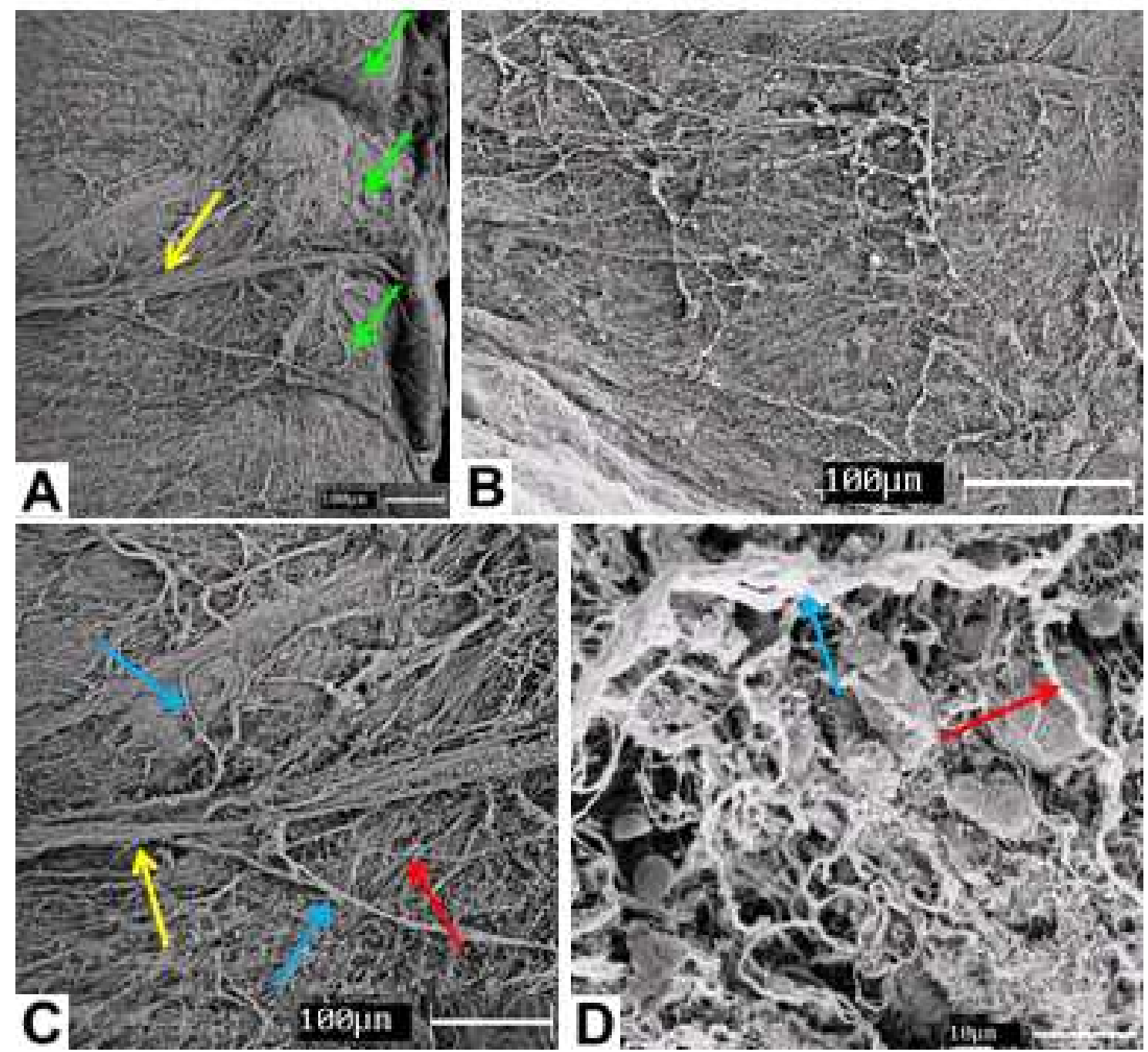

Figura 23 - Eletronmicrografias de varredura do plexo traqueal. Aspectos gerais da malha constituída pelos feixes de fibras nervosas. A - Observar a disposição do feixe constituinte da malha primária (seta amarela) dirigindose aos espaços entre os anéis traqueais (setas verdes). B - Distribuição da malha do plexo, de aspecto pantográfico, sobre a musculatura traqueal. C Em maior aumento, os aspectos dos feixes constituintes das malhas primária (seta amarela), secundária (seta azul) e terciária (seta vermelha). D - Destacam-se as delgadas fibrilas constituintes da malha terciária (seta vermelha) provenientes da malha secundária (seta azul). (Barras de calibração: A-D - $100 \mu \mathrm{m})$. 


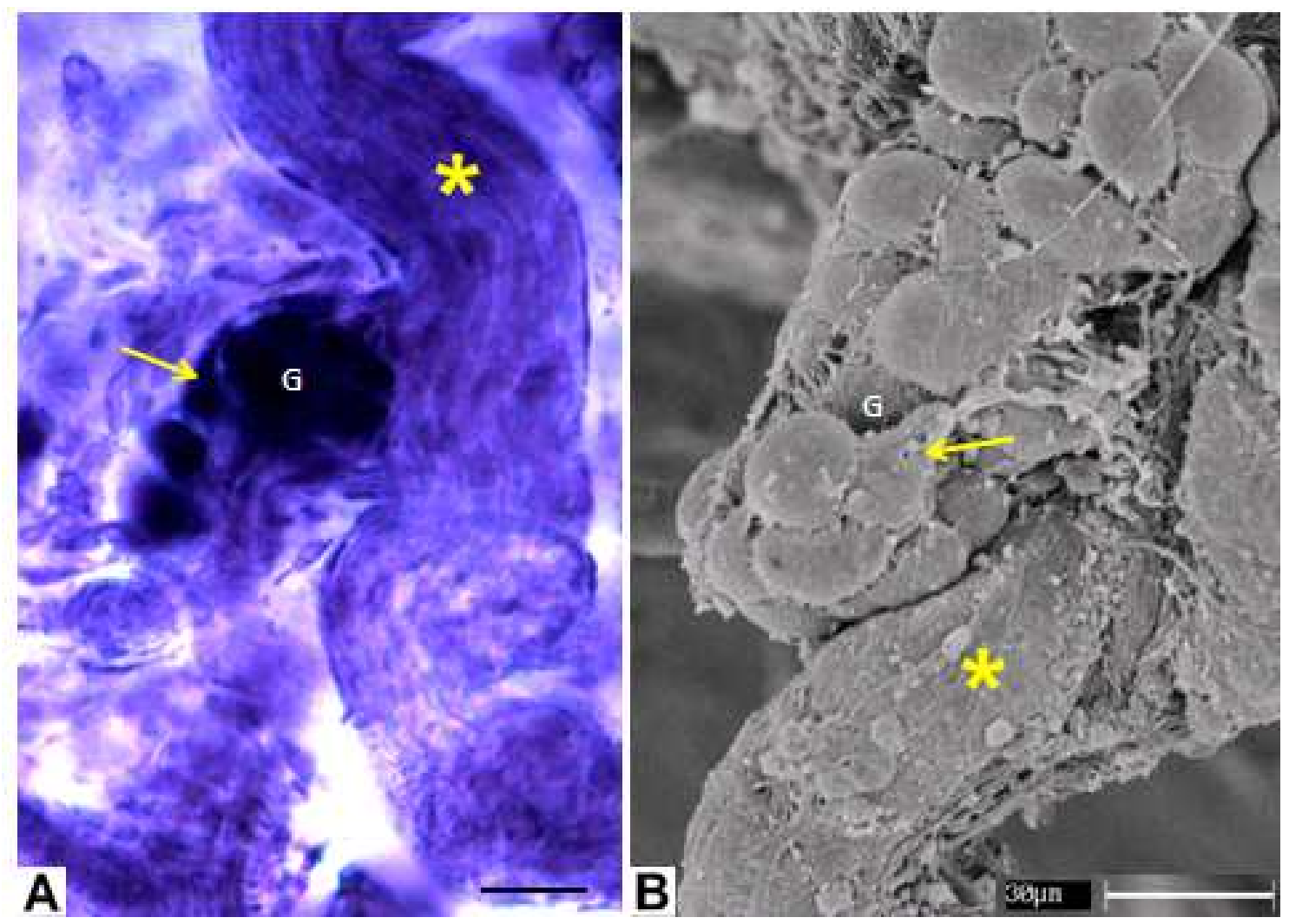

Figura 24 - Constituintes do plexo traqueal evidenciados sob as técnicas de microscopia de luz (A) e eletrônica de varredura (B). Notar, em ambas as técnicas, a morfologia e a disposição dos neurônios no interior dos gânglios (G), bem como a estreita relação destes com o feixe de fibras nervosas constituintes das malhas do plexo $\left(^{*}\right)$. (A - NADPH-d). (Barras de calibração: A - $25 \mu \mathrm{m}$; B - $30 \mu \mathrm{m}$ ). 

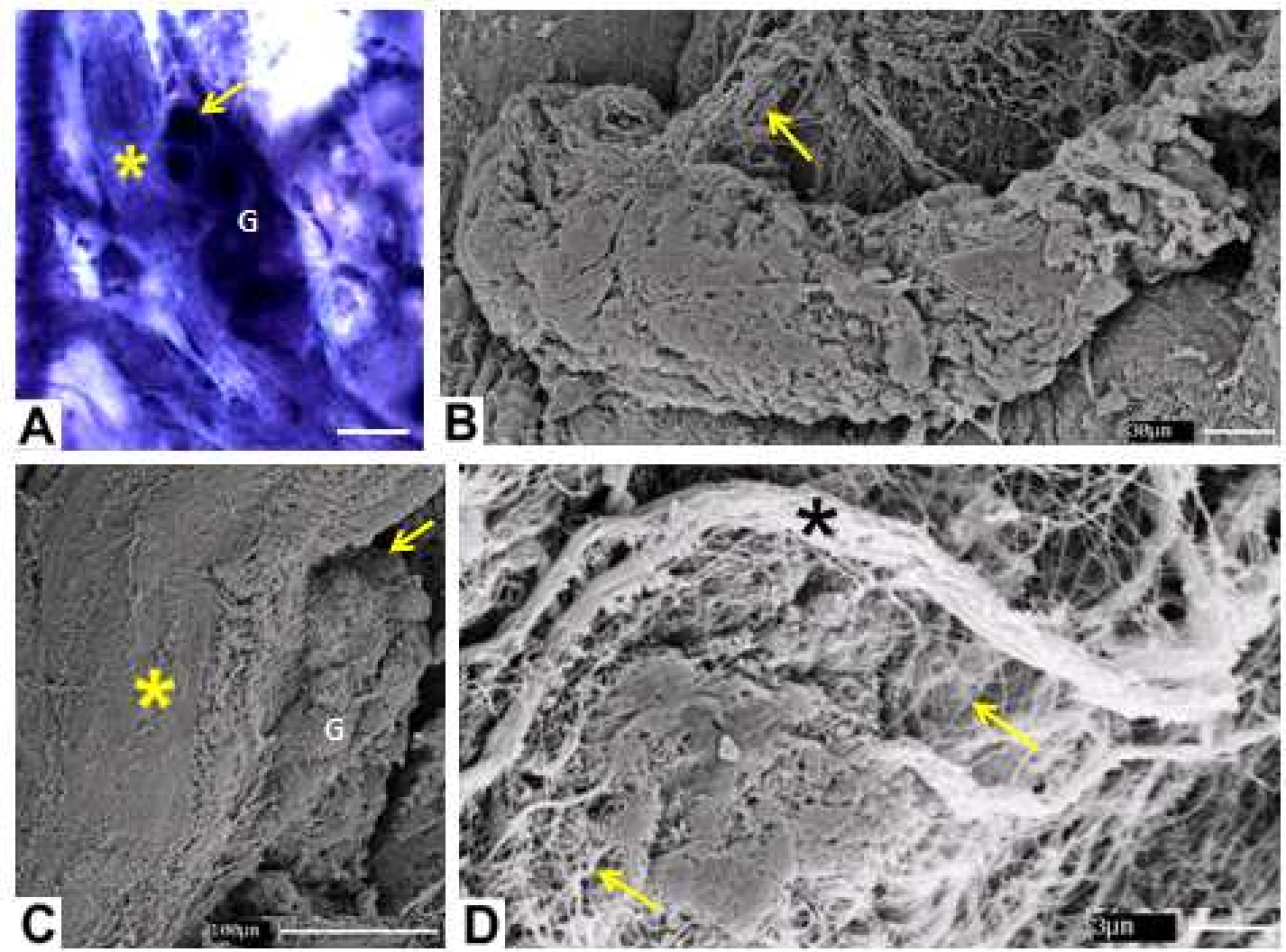

Figura 25 - Constituintes do plexo traqueal evidenciados pelas técnicas de microscopia de luz (A) e eletrônica de varredura (B-D). Notar em A, os corpos neuronais (seta) no interior do gânglio $(G)$ e o feixe de fibras nervosas anexas $\left(^{*}\right)$. Em B, gânglio com cápsula parcialmente corroída e delgados feixes de fibras nervosas penetrando no seu interior (seta). C - Feixe espesso de fibras nervosas anexas ao gânglio $\left(^{*}\right)$ e corpos neuronais (seta) evidenciados através da cápsula do gânglio parcialmente corroída. D - Feixe de fibras nervosas das malhas do plexo $\left(^{*}\right)$ e fibrilas colágenas constituintes da cápsula ganglionar, remanescentes do processo de corrosão ao qual foi submetida. (A - NADPH-d). (Barras de calibração: A $25 \mu \mathrm{m}, \mathbf{B}-30 \mu \mathrm{m}$; C - $100 \mu \mathrm{m}$; D - $3 \mu \mathrm{m})$. 

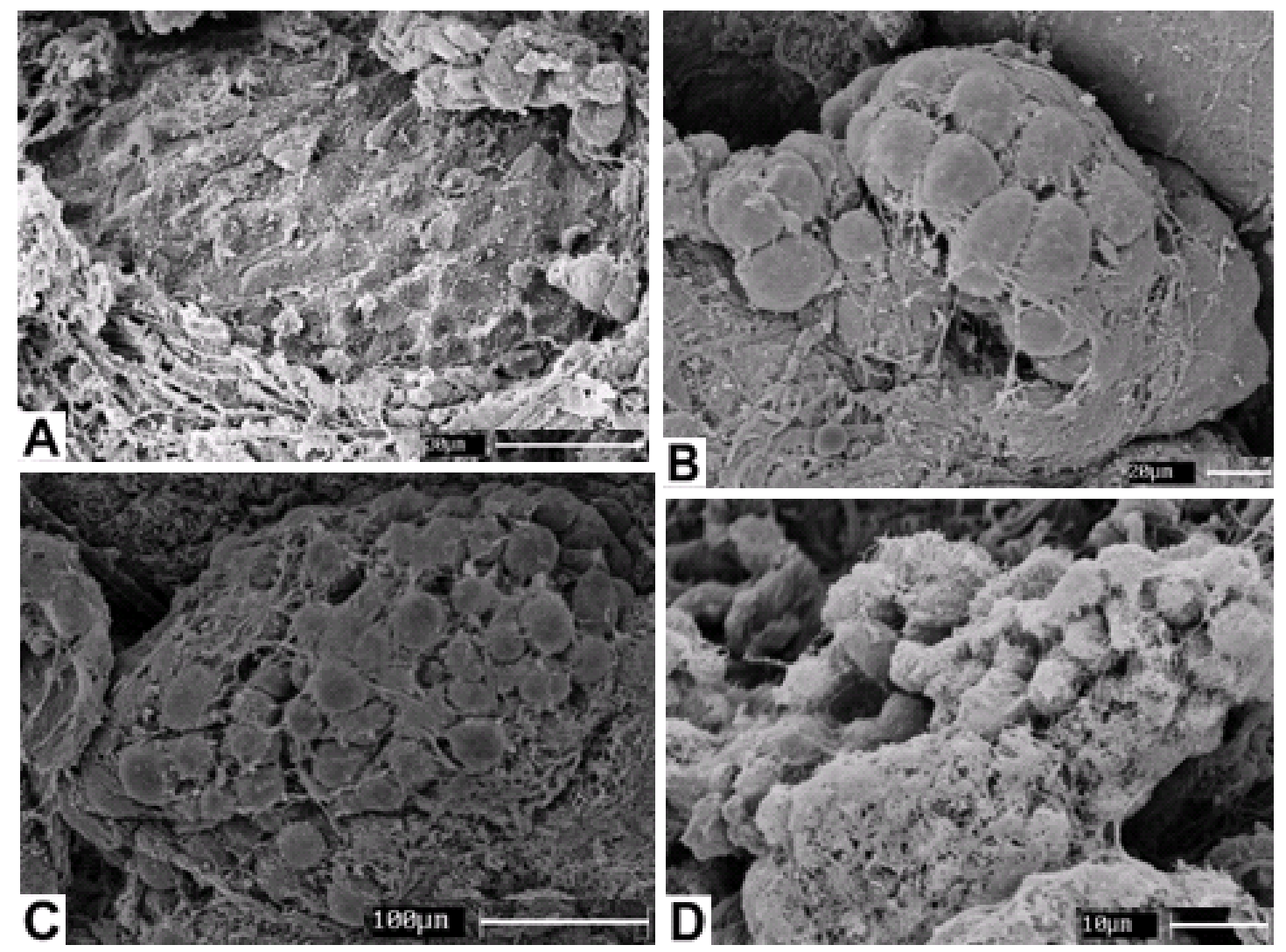

Figura 26 - Eletronmicrografias de varredura evidenciando gânglios do plexo traqueal em diferentes fases do processo de corrosão da cápsula ganglionar. Notar em A, o início da corrosão, com os corpos neuronais salientando-se sob a cápsula. B-C - Fase mais adiantada, evidenciando-se os corpos neuronais e alguns resquícios das fibrilas colágenas da cápsula. D - Estágio avançado do processo de corrosão, onde se verifica o início da digestão dos corpos neuronais. (Barras de calibração: A - $30 \mu \mathrm{m}$; B - $20 \mu \mathrm{m}$; C - 100 $\mu \mathrm{m} ; \mathbf{D}-10 \mu \mathrm{m})$. 

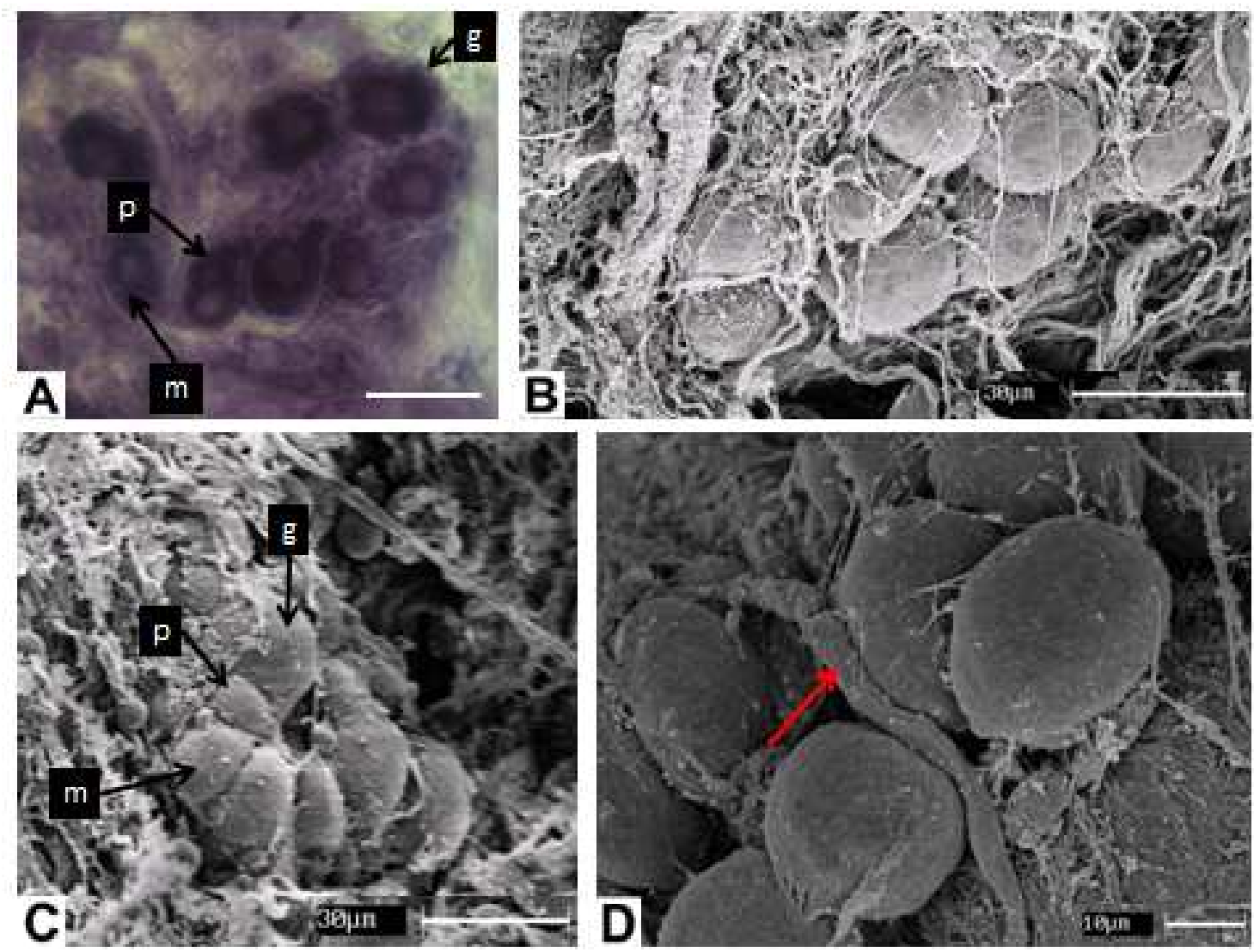

Figura 27 - Neurônios constituintes dos gânglios do plexo traqueal evidenciados pelas técnicas de microscopias de luz (A) e eletrônica de varredura (B-D). A,C Notar os diferentes tamanhos dos corpos neuronais - $\mathrm{p}$ : pequeno; $\mathrm{m}$ : médio; g: grande. Em $\mathbf{D}$ a seta indica um feixe da malha terciária interposto entre os corpos neuronais. (A - NADPH-d). (Barras de calibração: $\mathbf{A}$ - 25 $\mu \mathrm{m}$; B-C - $30 \mu \mathrm{m}$; D - $10 \mu \mathrm{m})$.

\subsection{Aspectos quantitativos}

Neste item, serão descritos os resultados referentes ao número total e à área do perfil dos neurônios e gânglios, reativos às técnicas NADH-d e NADPH-d.

\subsubsection{Número de neurônios e de gânglios reativos à NADH-d}

O número de neurônios variou de 151 a 381 no grupo N, de 43 a 534 no grupo D e de 171 a 411 no grupo R. O número médio de neurônios foi de 242,6 $( \pm 100,2)$ para o grupo $N$, de $279,2( \pm 194,1)$ para o grupo D e de $274,2( \pm 107,4)$ para o grupo $R$ (Figura 28). 


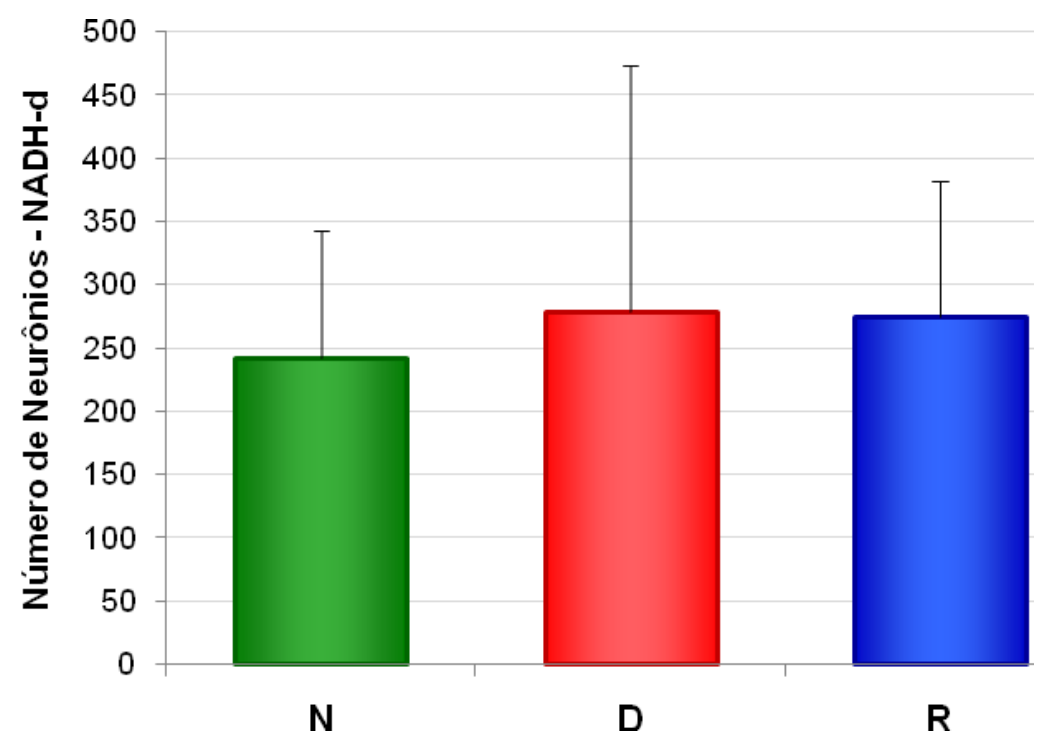

Figura 28 - Representação gráfica da média $( \pm D P)$ do número total de neurônios reativos à NADH-d nos grupos Nutrido (N), Desnutrido (D) e Renutrido $(\mathrm{R})$.

A análise estatística permitiu verificar que não existe diferença entre as médias dos diferentes grupos ( $p=0,941)$; todavia, verificou-se uma tendência para um aumento na média dos neurônios do grupo $D$.

Quando se analisou o número de gânglios verificou-se que esse número variou de 18 a 41 no grupo $\mathrm{N}$; de 3 a 63 no grupo $\mathrm{D}$ e de 27 a 59 no grupo $\mathrm{R}$. Quanto ao número médio, o grupo $N$ apresentou 31,6 ( \pm 10$)$; o grupo D 30,4 ( \pm 22$)$ e o grupo $R, 40,8( \pm 15,4)$ gânglios. Ao se avaliar estatisticamente esses dados verificou-se não existir diferença significante para essa variável entre os grupos $(p=0,512)$. A figura 29 apresenta os dados referentes à média do número total de gânglios do plexo traqueal nos diferentes grupos.

Ao se relacionar a média da razão neurônios reativos à NADH-d por gânglio (neurônios/gânglio), observou-se que as razões mínima e máxima foram, respectivamente, de 5,8 e 9,3 no grupo $\mathrm{N}$; de 7,7 e 14,3 no grupo $\mathrm{D}$ e de 5,3 e 8 no grupo R. Quanto ao número médio de neurônios por gânglio observou-se para o grupo N 7,6 $( \pm 1,5), 10,1( \pm 2,7)$ para o grupo D e $6,7( \pm 1) \circ$ grupo R. 


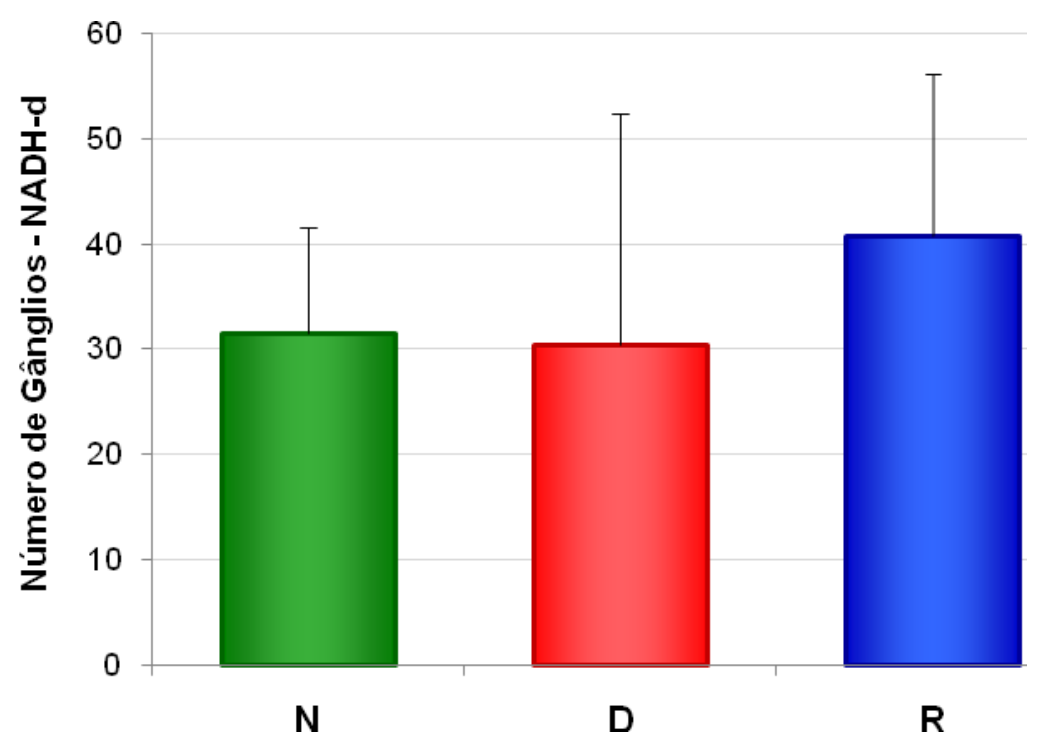

Figura 29 - Representação gráfica da média $( \pm D P)$ do número total de gânglios reativos à NADH-d nos grupos Nutrido (N), Desnutrido (D) e Renutrido $(\mathrm{R})$.

Após a análise estatística verificou-se diferença significativa entre os grupos $D$ e $R$, evidenciando maior razão neurônios/gânglio no grupo $D$ do que no grupo $R(p<0,05)$. Ao se comparar os grupos $D$ e $R$ com o grupo controle $(\mathrm{N})$, não foram observadas diferenças significantes $(p>0,05)$ (Figura 30$)$.

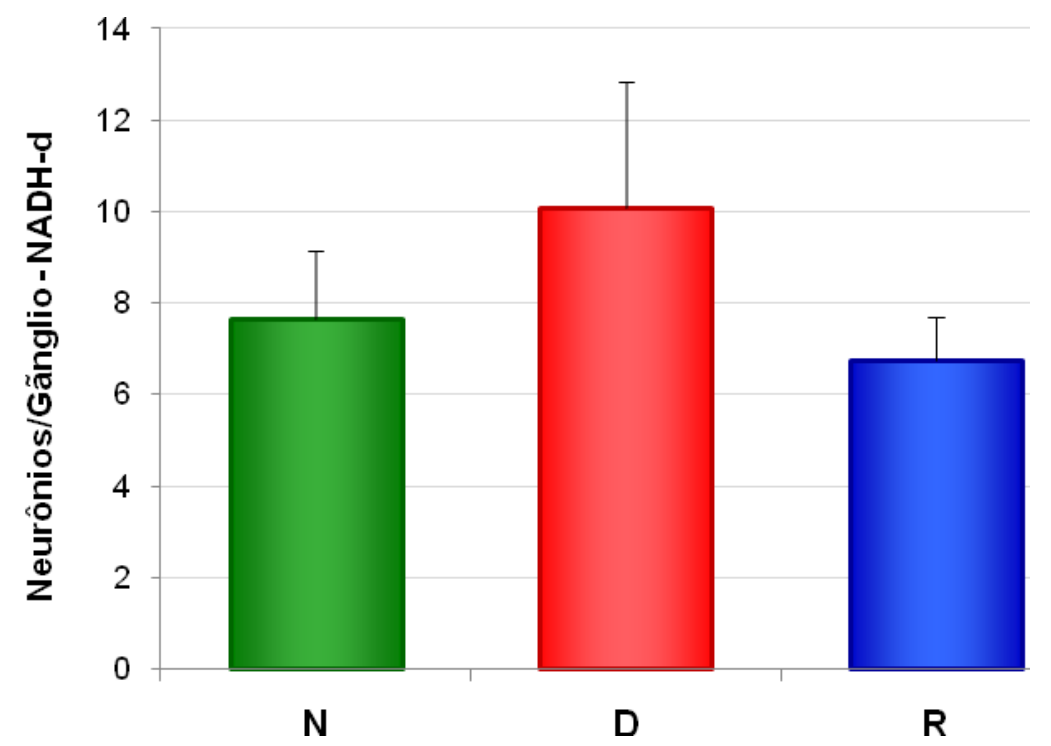

Figura 30 - Representação gráfica da média $( \pm D P)$ da razão neurônios/gânglio reativos à NADH-d nos grupos Nutrido (N), Desnutrido (D) e Renutrido (R). 
Ao se avaliar entre os grupos ( $N, D$ e $R$ ) os dados referentes ao número de neurônios e de gânglios e a razão neurônios/gânglio nas metades cervical e torácica da traquéia, obteve-se os dados a seguir. Relativamente ao número total de neurônios, independentemente dos grupos, a metade torácica apresentou maior quantidade de neurônios $(p<0,001)$, tendo sido verificado o mesmo para $o$ número total de gânglios $(p<0,001)$ e para a razão neurônios/gânglio $(p<0,05)$ (Figuras 31-33).

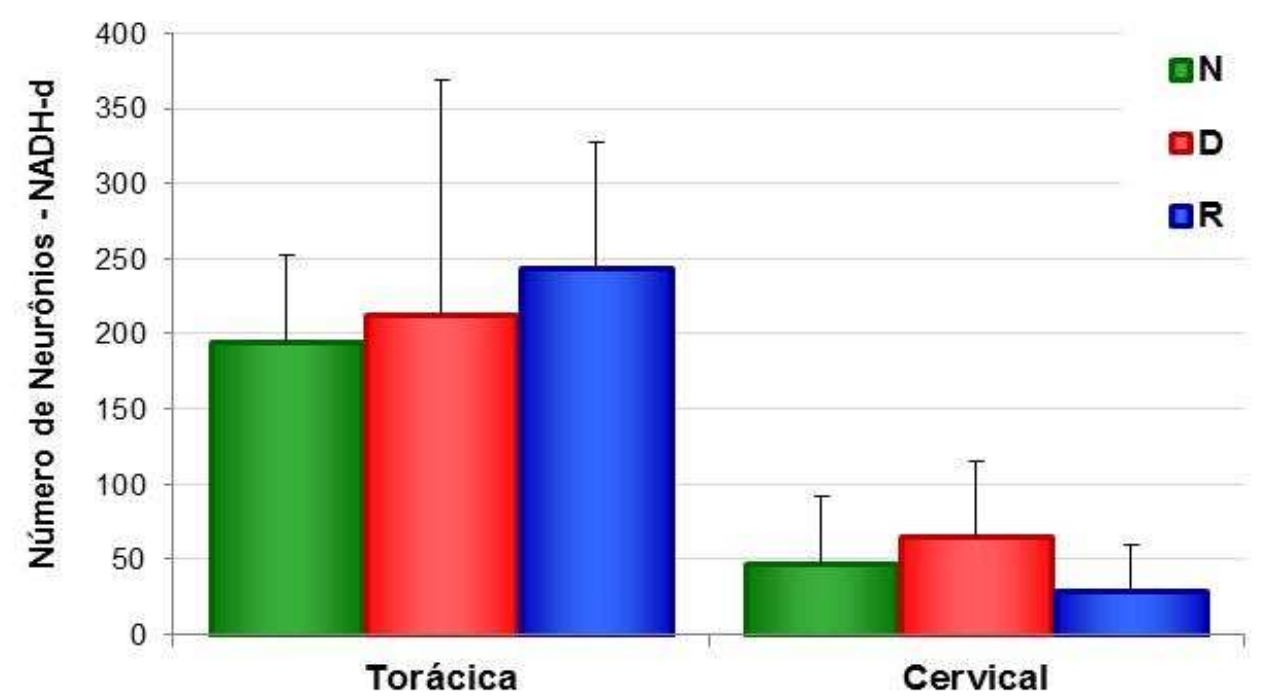

Figura 31 - Distribuição do número total $( \pm D P)$ de neurônios reativos à NADH-d nas metades cervical e torácica nos grupos Nutrido (N), Desnutrido (D) e Renutrido (R).

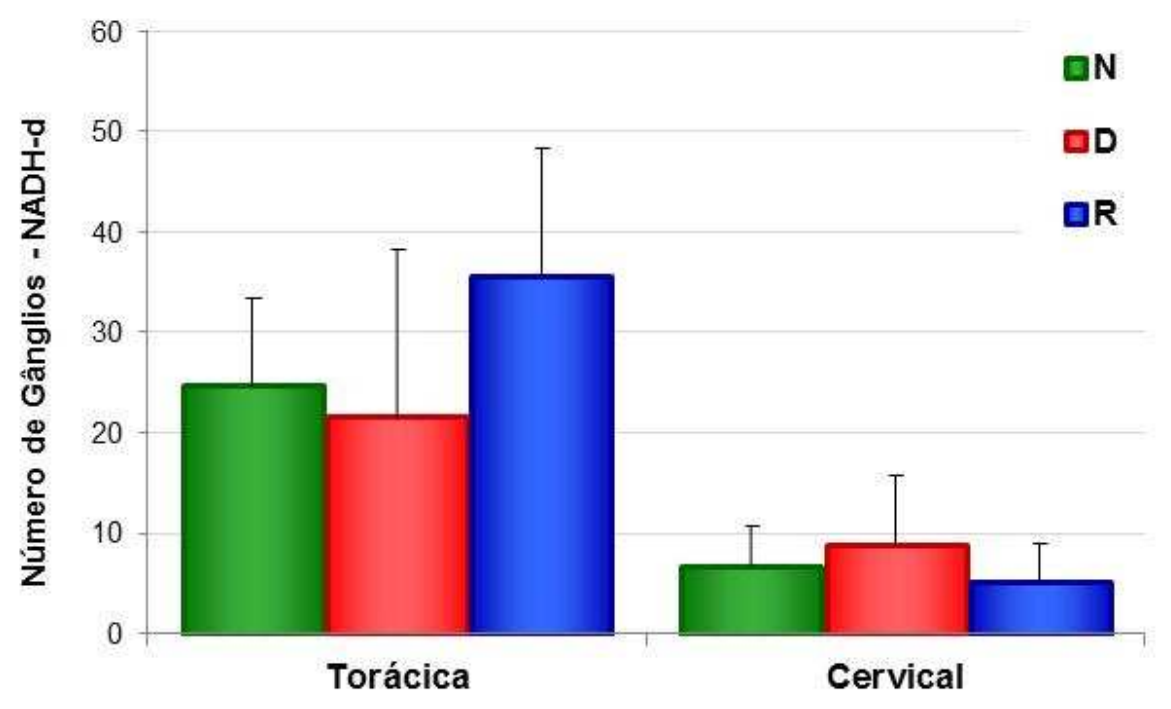

Figura 32 - Distribuição do número total $( \pm D P)$ de gânglios reativos à NADH-d nas metades cervical e torácica nos grupos Nutrido (N), Desnutrido (D) e Renutrido (R). 


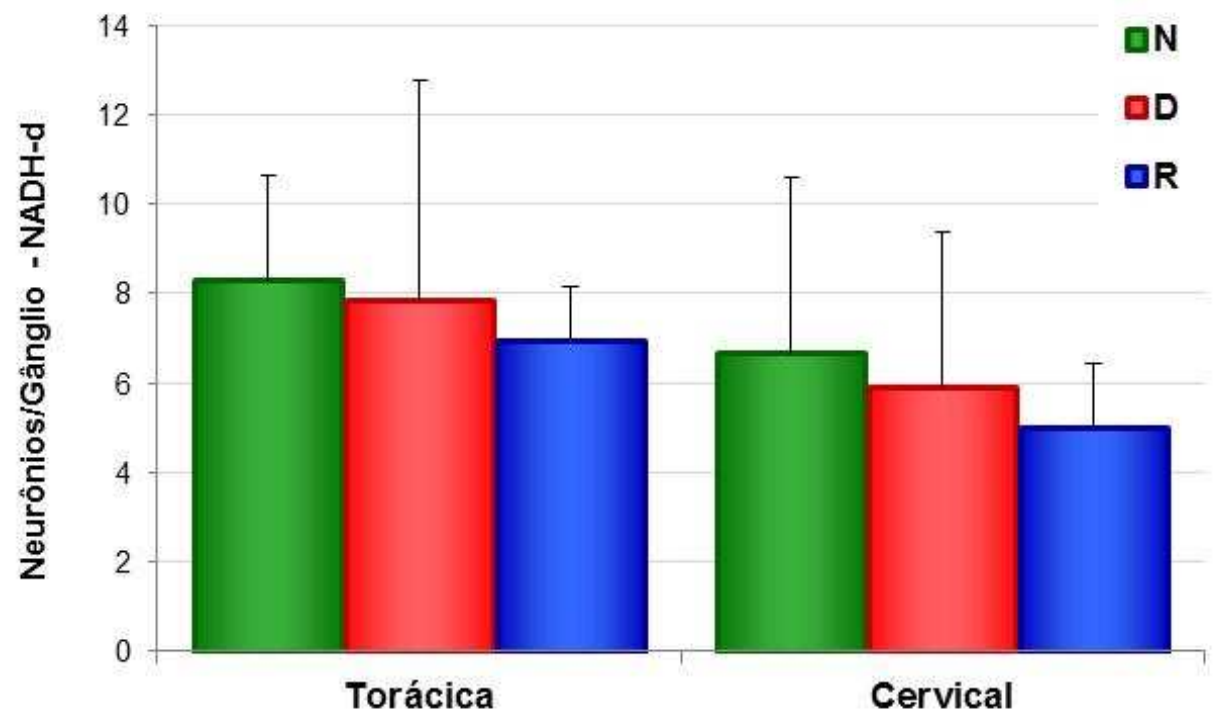

Figura 33 - Distribuição da média ( $\pm D P)$ da razão neurônios/gânglio reativos à NADH-d nas metades cervical e torácica nos grupos Nutrido $(N)$, Desnutrido (D) e Renutrido $(R)$.

\subsubsection{Número de neurônios e de gânglios reativos à NADPH-d}

O número de neurônios variou de 94 a 366 no grupo N, de 201 a 443 no grupo $D$, de 136 a 432 no grupo R. O número médio de neurônios foi de 215,8 $( \pm 97,7)$ para o grupo $N$, de $320,8( \pm 98,7)$ para o grupo $D$ e de $292( \pm 120,8)$ para o grupo R (Figura 34).

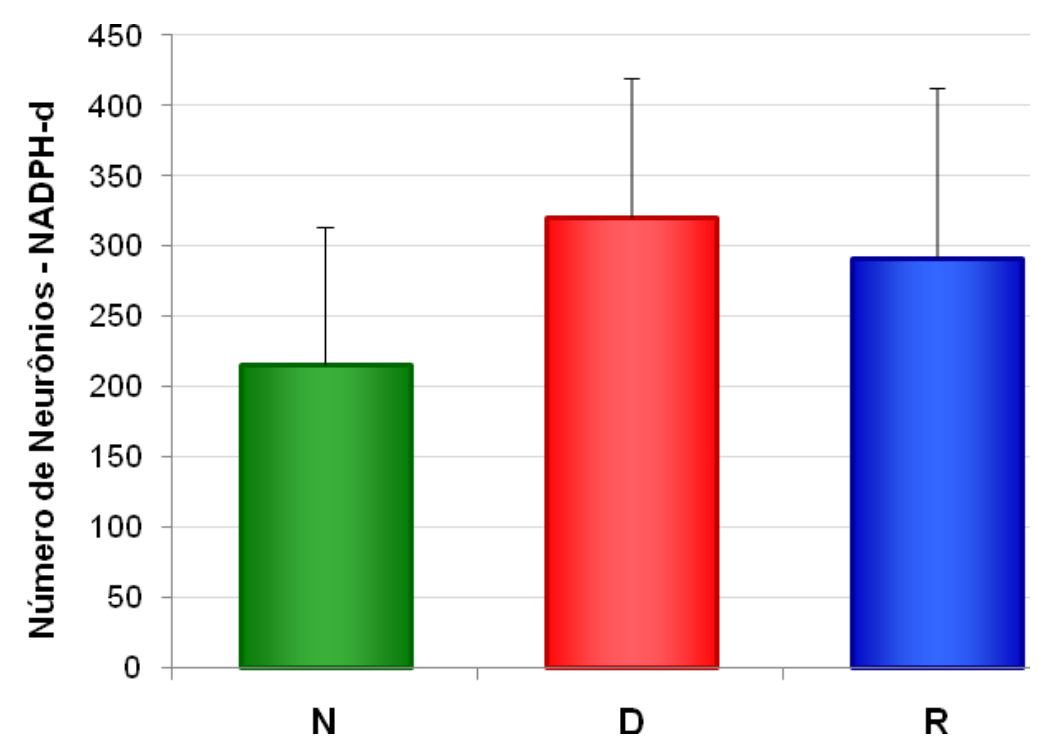

Figura 34 - Representação gráfica da média $( \pm D P)$ do número total de neurônios reativos à NADPH-d nos grupos Nutrido (N), Desnutrido (D) e Renutrido $(\mathrm{R})$. 
A análise estatística permitiu observar que não existe diferença estatística entre as médias dos diferentes grupos $(p=0,292)$; todavia, verificouse uma tendência para um aumento na média dos neurônios do grupo $D$.

A figura 35 apresenta os dados referentes à média do número total de gânglios. Quando se avalia o número total de gânglios, verificou-se que esse número variou de 15 a 40 no grupo $\mathrm{N}$; de 22 a 53 no grupo $\mathrm{D}$ e de 21 a 45 no grupo $R$, sendo o número médio de $32,6( \pm 10,3)$ para o grupo $\mathrm{N}$; $38( \pm 11,7)$ para o grupo D e $31,8( \pm 9,3)$ para o grupo $R$. Ao se avaliar estatisticamente esses dados, verificou-se não existir diferença significante para essa variável entre os grupos ( $p=0,649)$ (Figura 35$)$.

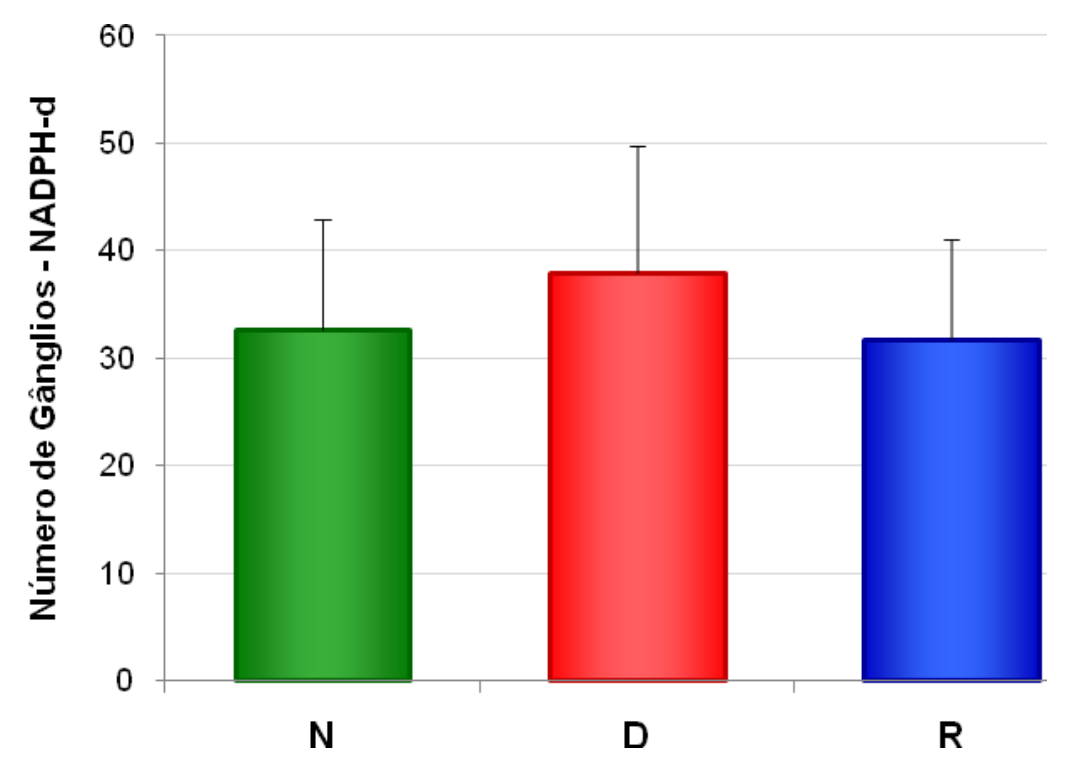

Figura 35 - Representação gráfica da média $( \pm D P)$ do número total de gânglios reativos à NADPH-d nos grupos Nutrido (N), Desnutrido (D) e Renutrido (R).

Ao se relacionar a média da razão neurônios reativos à NADPH-d por gânglio (neurônios/gânglio), observou-se que as razões mínima e máxima foram, respectivamente, de 5 e 9,2 no grupo $\mathrm{N}$; de 6,9 e 13 no grupo $\mathrm{D}$ e de 6,5 e 11,1 no grupo R. Quanto ao número médio de neurônios por gânglio observou-se para o grupo N 6,6 $( \pm 1,6), 8,7( \pm 2,6)$ para o grupo D e $8,9( \pm 1,7)$ para o grupo R. Após análise estatística dos dados, constatou-se que não houve diferença significante entre os grupos estudados ( $p=0,162)$; porém, a menor média foi observada no grupo N. (Figura 36). 


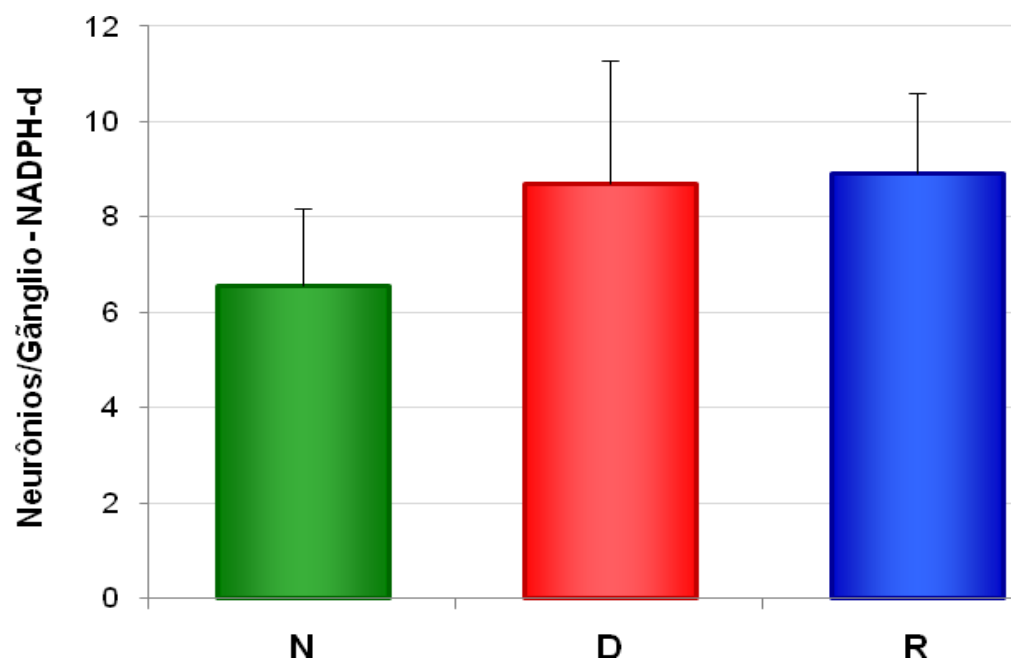

Figura 36 - Representação gráfica da média $( \pm D P)$ da razão neurônios/gânglio reativos à NADPH-d nos grupos Nutrido (N), Desnutrido (D) e Renutrido (R).

Ao se avaliar entre os grupos ( $N, D$ e $R$ ) os dados referentes ao número de neurônios e de gânglios e a razão neurônios/gânglio nas metades cervical e torácica da traquéia, obteve-se os dados a seguir. Relativamente ao número total de neurônios, independentemente dos grupos, a metade torácica apresentou maior quantidade de neurônios $(p<0,001)$, tendo sido verificado $o$ mesmo para $o$ número total de gânglios $(p<0,001)$ e para a razão neurônios/gânglio $(p<0,05)$ (Figuras 37-39).

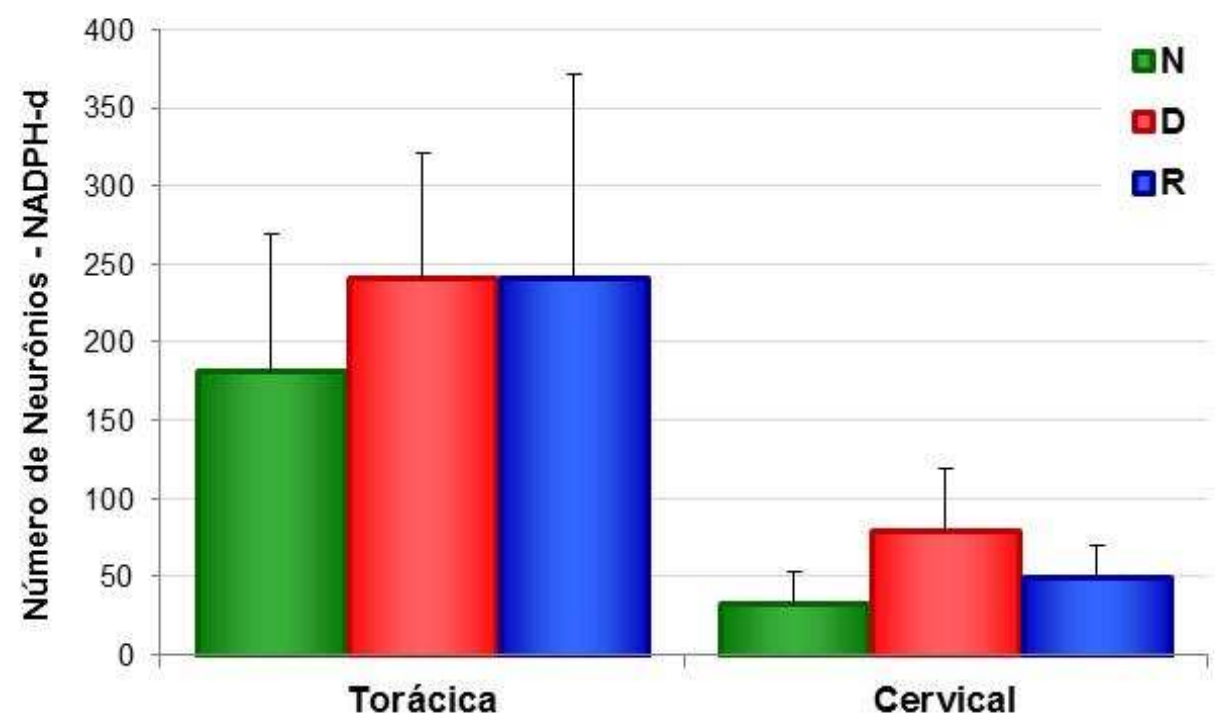

Figura 37 - Distribuição do número total $( \pm D P)$ de neurônios reativos à NADPH-d nas metades cervical e torácica nos grupos Nutrido $(N)$, Desnutrido (D) e Renutrido (R). 


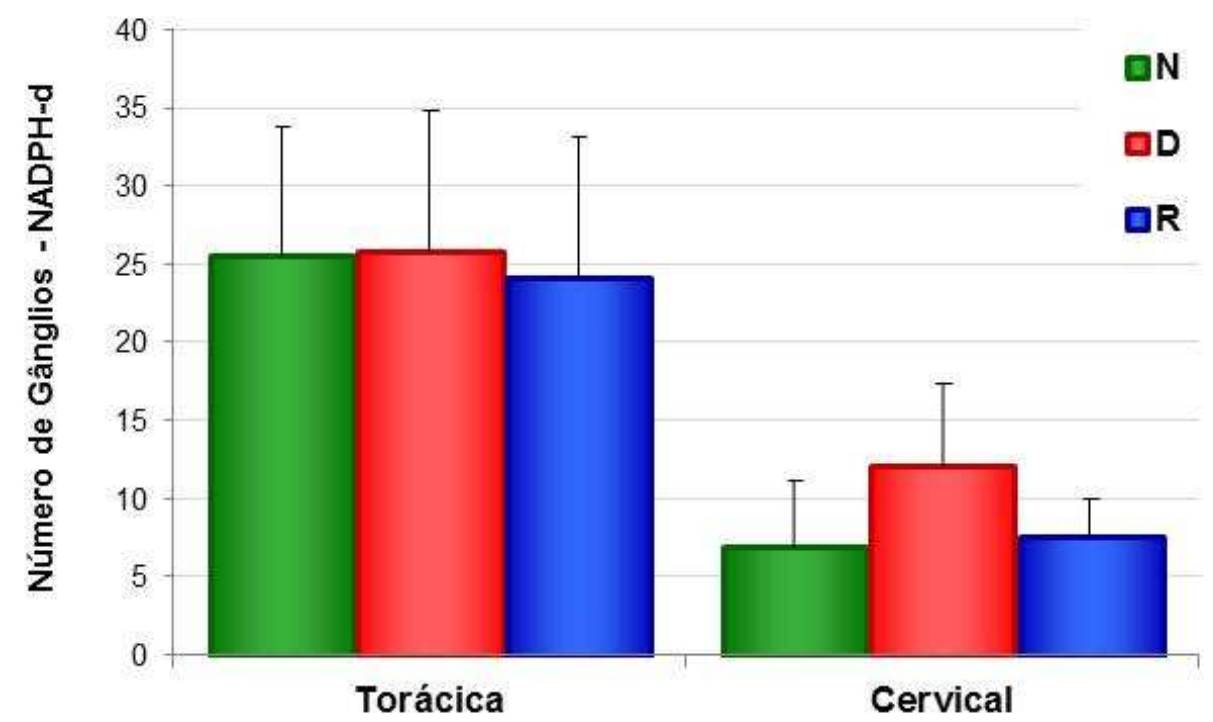

Figura 38 - Distribuição do número total $( \pm D P)$ de gânglios reativos à NADPH-d nas metades cervical e torácica nos grupos Nutrido $(N)$, Desnutrido (D) e Renutrido $(\mathrm{R})$.

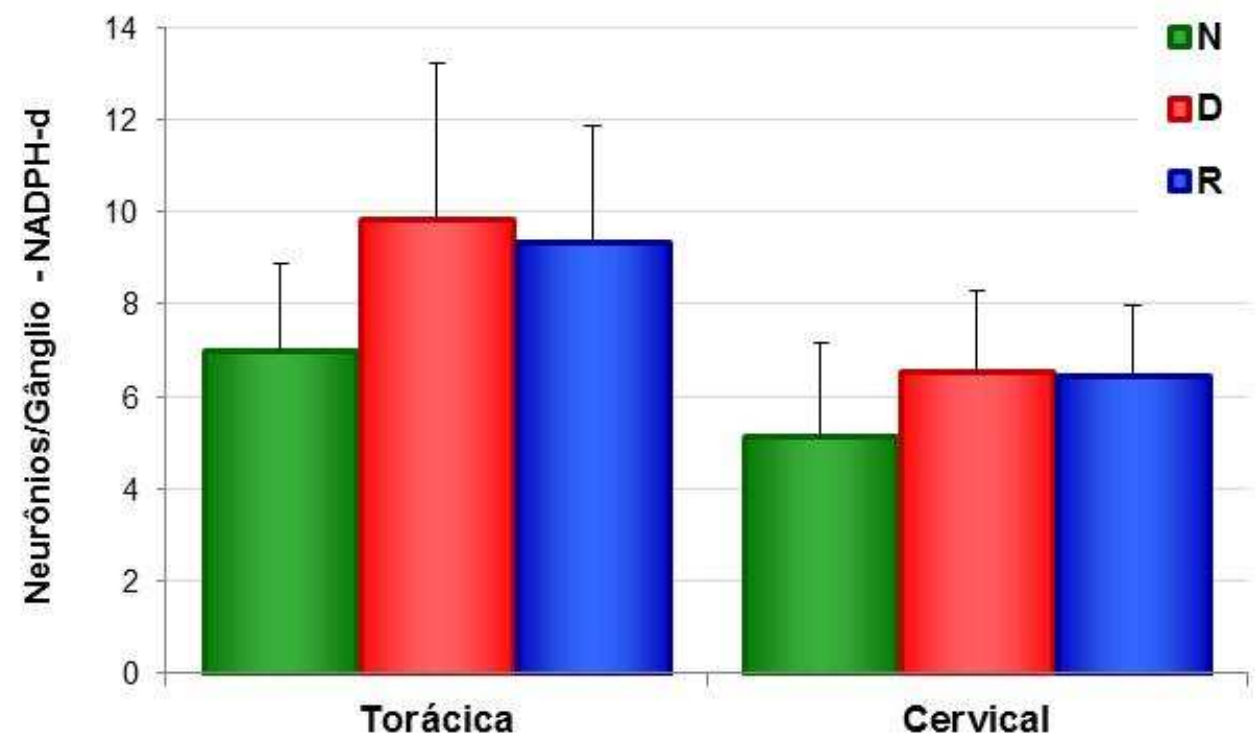

Figura 39 - Distribuição da média $( \pm D P)$ da razão neurônios/gânglio reativos à $\mathrm{NADPH}-\mathrm{d}$ nas metades cervical e torácica nos grupos Nutrido $(\mathrm{N})$, Desnutrido (D) e Renutrido (R).

\subsection{3 Área do perfil dos neurônios e gânglios reativos à NADH-d}

A área do perfil neuronal do grupo $\mathrm{N}$ variou de $412,4 \mu \mathrm{m}^{2}$ a $504,8 \mu \mathrm{m}^{2}$ (com média de 455,6 $\pm 34,7 \mu \mathrm{m}^{2}$ ); de 101,7 $\mu \mathrm{m}^{2}$ a 221,5 $\mu \mathrm{m}^{2}$ (com média de 
$146 \pm 47,5 \mu \mathrm{m}^{2}$ ) no grupo $\mathrm{D}$ e de $166,8 \mu \mathrm{m}^{2}$ a $363,1 \mu \mathrm{m}^{2}$ (com média de $268,8 \pm 71,4 \mu \mathrm{m}^{2}$ ) no grupo R (Figuras 40 e 41 ).

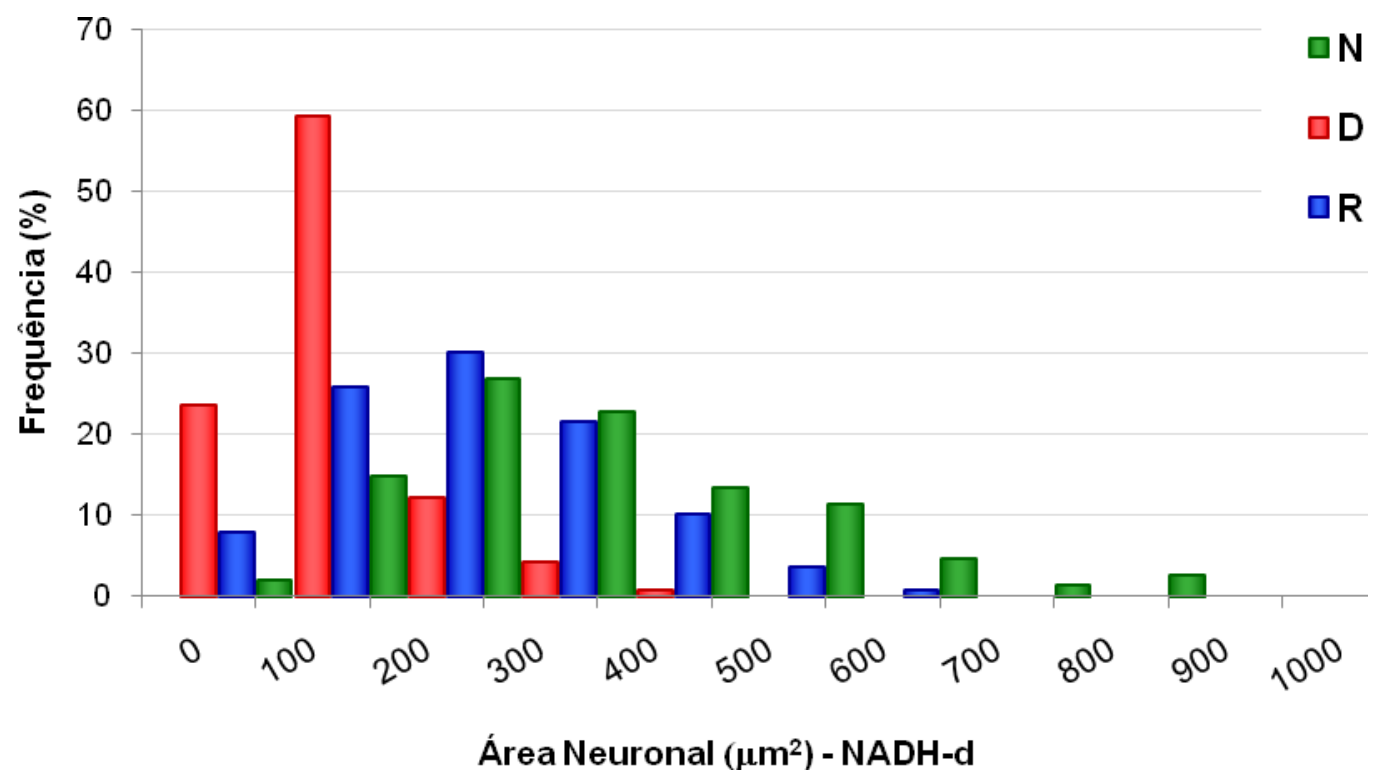

Figura 40 - Distribuição da área média do perfil celular NADH-d reativos $\left(\mu \mathrm{m}^{2}\right)$ nos grupos Nutrido (N), Desnutrido (D) e Renutrido (R).

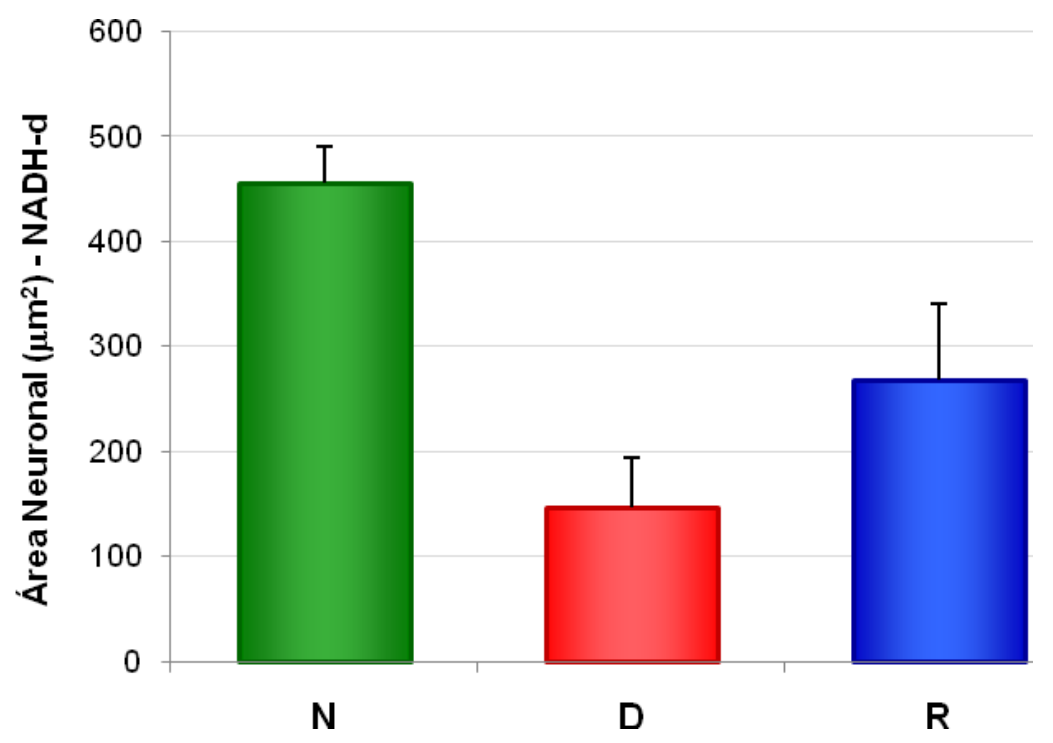

Figura 41 - Representação gráfica da média $( \pm D P)$ da área dos neurônios reativos à $\mathrm{NADH}-\mathrm{d}$ nos grupos Nutrido (N), Desnutrido (D) e Renutrido (R).

Ao se analisar os dados da figura 40 , verificou-se que a maior concentração neuronal do grupo $\mathrm{N}$ encontra-se no intervalo de 300 a $400 \mu \mathrm{m}^{2}$, representando $26,8 \%$ dos neurônios; no grupo $D$ foram encontrados $59,3 \%$ dos 
neurônios no intervalo de 100 a $200 \mu \mathrm{m}^{2}$ sendo que para o grupo $\mathrm{R}$, a maior concentração dos neurônios encontra-se no intervalo de 200 a $300 \mu \mathrm{m}^{2}$ com $30,2 \%$.

Quanto às médias (Figura 41), foram observadas diferenças estatísticas entre todos os grupos $(p<0,05)$. Assim, os neurônios do grupo $\mathrm{N}$ são maiores em relação aos neurônios dos grupos experimentais $D$ e $R$; quando estes são comparados entre si, os neurônios do grupo $\mathrm{R}$ são maiores do que aqueles do grupo D.

A área do perfil ganglionar no grupo $\mathrm{N}$ variou de $2910,8 \mu \mathrm{m}^{2}$ a 6890,5 $\mu \mathrm{m}^{2}$ (com média de 4595,1 $\pm 1607,2 \mu \mathrm{m}^{2}$ ), de $1542,7 \mu \mathrm{m}^{2}$ a $2590 \mu \mathrm{m}^{2}$ (com média de $2007 \pm 447,9 \mu \mathrm{m}^{2}$ ) no grupo $\mathrm{D}$ e de $1486 \mu \mathrm{m}^{2}$ a $3558,4 \mu \mathrm{m}^{2}$ (com média de $2555,6 \pm 748,2 \mu \mathrm{m}^{2}$ ) no grupo R (Figuras 42 e 43 ).

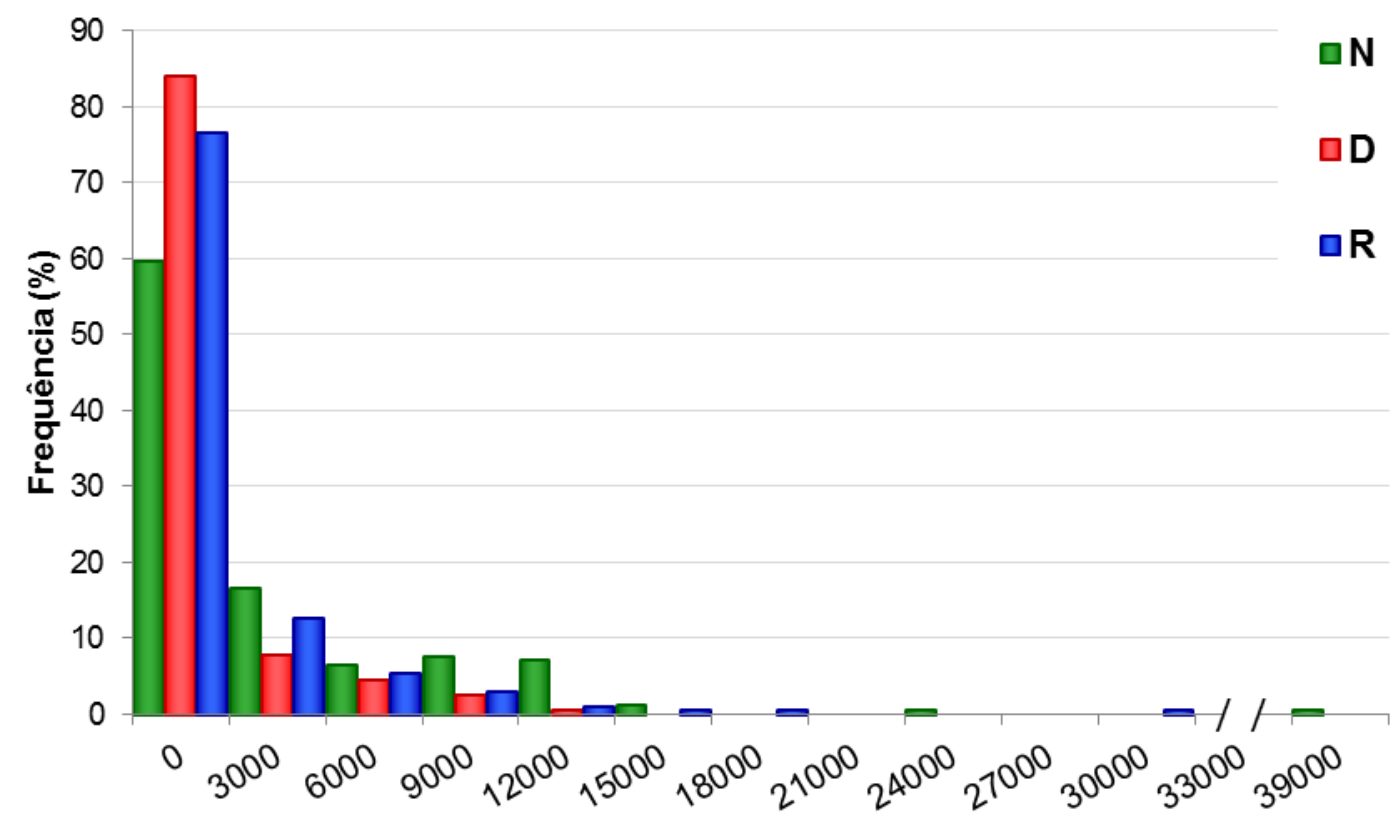

Área Ganglionar $\left(\mu \mathrm{m}^{2}\right)$ - NADH-d

Figura 42 - Distribuição da área média do perfil ganglionar NADH-d reativos $\left(\mu m^{2}\right)$ nos grupos Nutrido (N), Desnutrido (D) e Renutrido (R). 


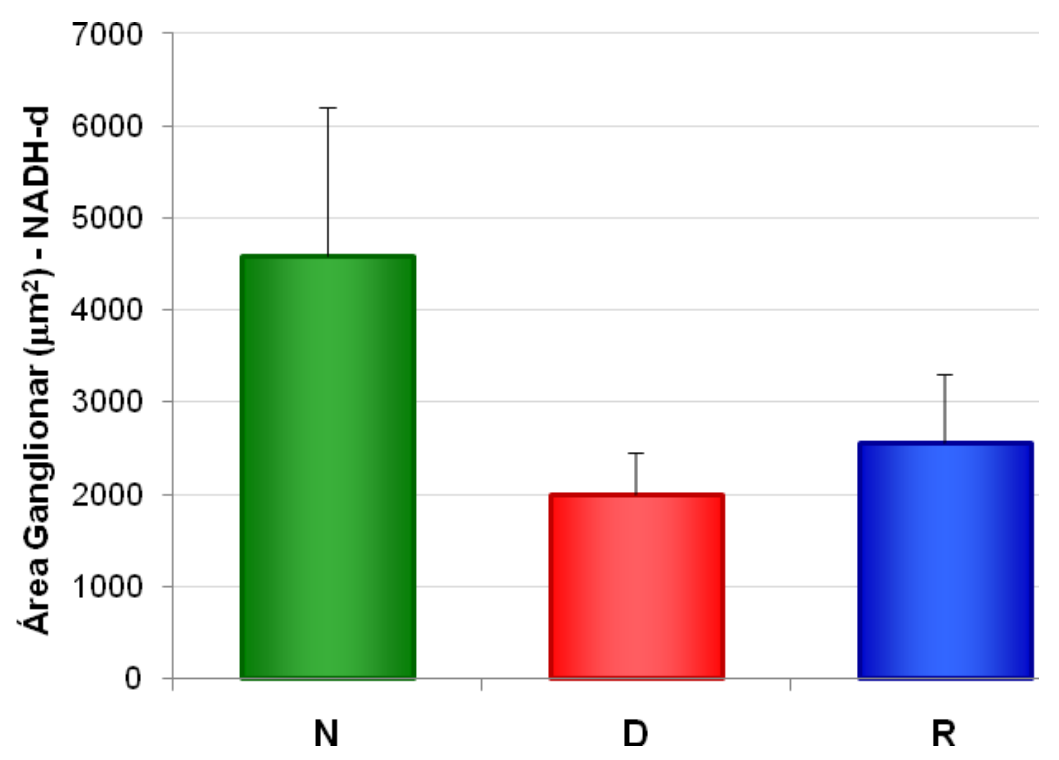

Figura 43 - Representação gráfica da média $( \pm D P)$ da área dos gânglios reativos à NADH-d nos grupos Nutrido (N), Desnutrido (D) e Renutrido (R).

Ao se analisar os dados da figura 42 , verificou-se que a maior concentração ganglionar de todos os grupos ( $N, D$ e R) encontra-se no intervalo de 0 a $3000 \mu \mathrm{m}^{2}$, representando no grupo $\mathrm{N} 59,61 \%$ dos gânglios, no grupo $D$, foram encontrados $84,21 \%$ dos gânglios e para o grupo $R, 76,59 \%$.

Quanto às médias (Figura 43), foram observadas diferenças estatísticas entre os gânglios do grupo $N$ quando comparados com os grupos $D$ e $R$ $(p<0,05)$, sendo os gânglios do grupo $N$ maiores do que os demais, não tendo sido observada diferença estatística quando os grupos $D$ e $R$ são comparados entre si $(p>0,05)$.

Ao se avaliar entre os grupos ( $N, D$ e R) os dados referentes à área do perfil neuronal e ganglionar nas metades cervical e torácica da traquéia verificou-se existir diferença significante entre os grupos $(p<0,05)$ em relação à área do perfil neuronal. Desta forma, os neurônios do grupo $\mathrm{N}$ apresentaram-se maiores do que os neurônios dos grupos $\mathrm{D}$ e $\mathrm{R}$ e, entre estes, os neurônios do grupo $R$ são maiores que os do grupo $D$, tanto na metade cervical, quanto na metade torácica da traquéia (Figura 44). 


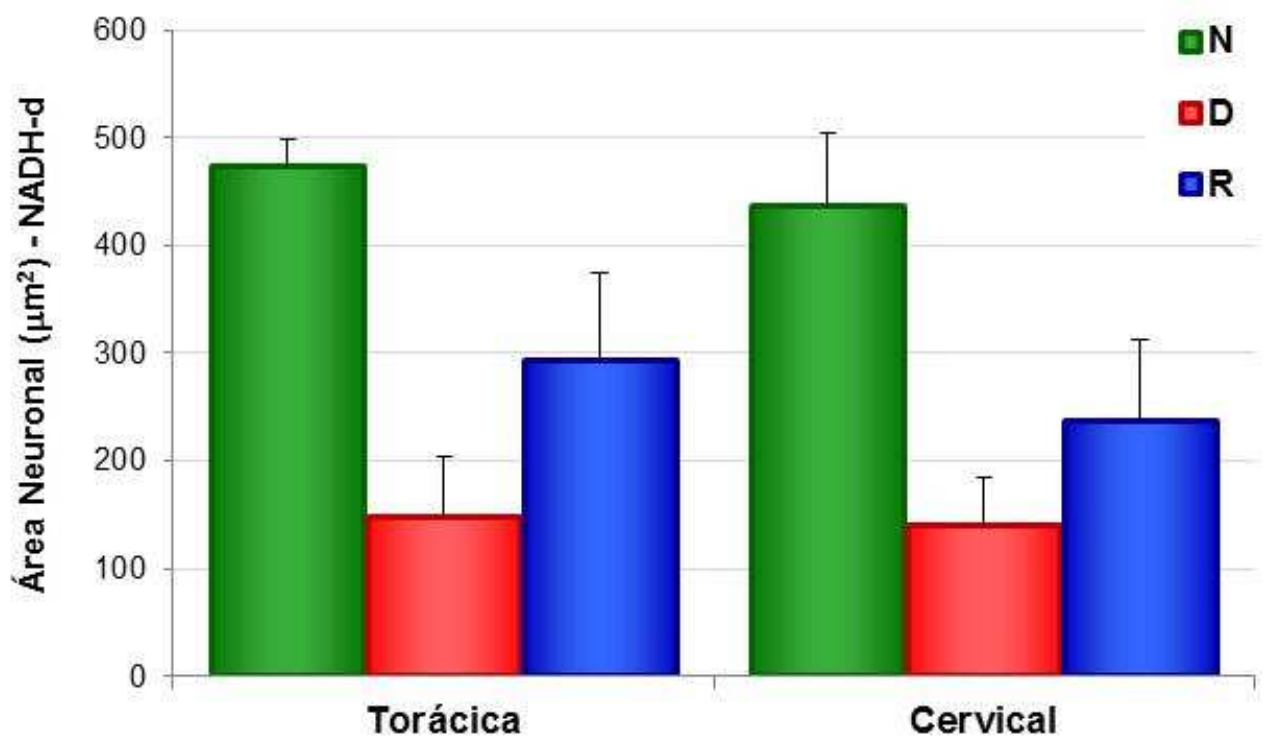

Figura 44 - Distribuição da área média $( \pm D P)$ de neurônios reativos à NADH-d nas metades cervical e torácica nos grupos Nutrido $(N)$, Desnutrido (D) e Renutrido (R).

Na figura 45 estão expressos os dados referentes à distribuição da área do perfil neuronal nas metades cervical e torácica da traquéia.

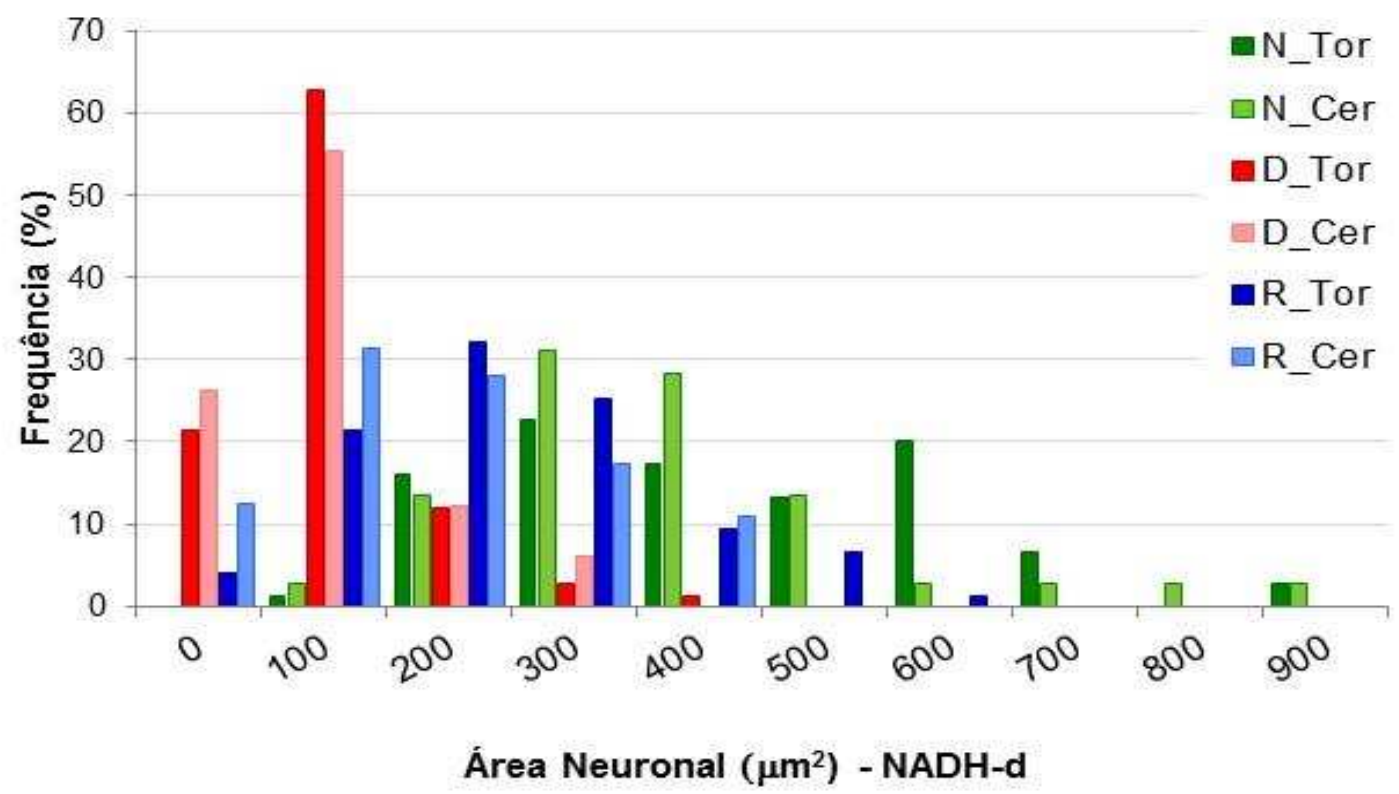

Figura 45 - Distribuição da área média do perfil neuronal NADH-d reativos $\left(\mu m^{2}\right)$ nas metades cervical e torácica nos grupos Nutrido $(N)$, Desnutrido $(D)$ e Renutrido (R).

A análise da figura permitiu verificar que no grupo $\mathrm{N}, 31,1 \%$ dos neurônios da metade cervical e $22,6 \%$ dos neurônios da metade torácica 
encontravam-se entre 300 e $400 \mu \mathrm{m}^{2}$; no grupo $\mathrm{D}$, a concentração dos neurônios da metade cervical e torácica encontrava-se entre 100 e $200 \mu \mathrm{m}^{2}$ (55,3\% e 62,6\%, respectivamente) e no grupo $R, 31,2 \%$ dos neurônios da metade cervical concentravam-se no intervalo entre 100 e $200 \mu^{2}$ e $32 \%$ da metade torácica, no intervalo compreendido entre 200 a $300 \mu \mathrm{m}^{2}$.

Quando analisada a área do perfil ganglionar, foi observada diferença significante entre os grupos $N, D$ e $R(p<0,05)$. Assim, verificou-se que os gânglios do grupo $\mathrm{N}$ são maiores do que os gânglios dos grupos $\mathrm{D}$ e $\mathrm{R}$ e, entre estes, não houve diferença $(p>0,05)$ (Figura 46). Ao se comparar as metades cervical e torácica, independente do fator grupo, observou-se diferença significante $(p=0,001)$, ou seja, os gânglios da metade torácica são maiores do que os gânglios da metade cervical.

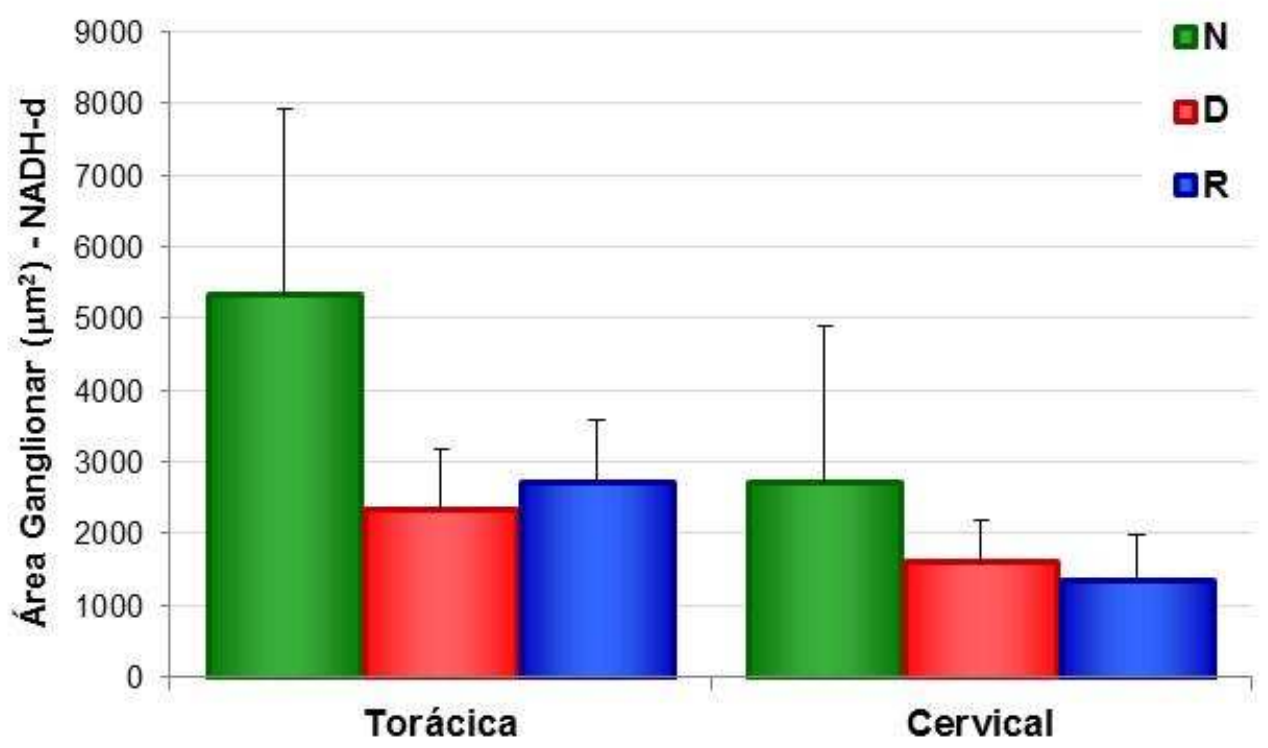

Figura 46 - Distribuição da área média $( \pm D P)$ dos gânglios reativos à NADH-d nas metades cervical e torácica nos grupos Nutrido $(\mathrm{N})$, Desnutrido (D) e Renutrido $(\mathrm{R})$.

Na figura 47 estão expressos os dados referentes à distribuição da área do perfil ganglionar nas metades cervical e torácica da traquéia. 


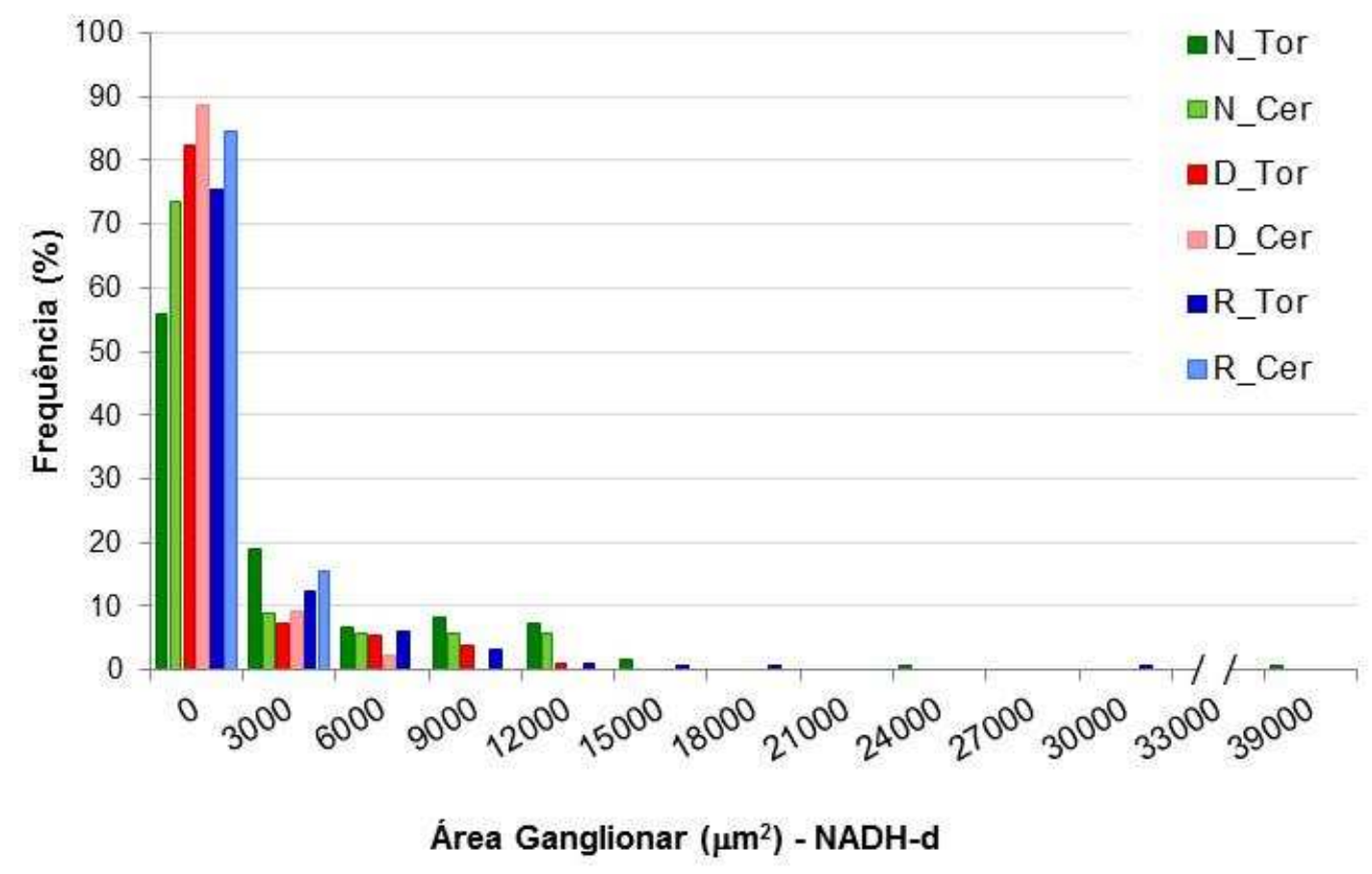

Figura 47 - Distribuição da área média do perfil ganglionar NADH-d reativos $\left(\mu m^{2}\right)$ nas metades cervical e torácica nos grupos Nutrido (N), Desnutrido (D) e Renutrido (R).

Ao se analisar os dados acima, verificou-se que a maior concentração dos gânglios de todos os grupos (N, D e R) estavam no intervalo entre 0 e 3000 $\mu \mathrm{m}^{2}$, sendo assim, no grupo $\mathrm{N}$ verificou-se na metade cervical $73,52 \%$ e na metade torácica $55,74 \%$ dos seus gânglios. No grupo $D$, a maior concentração dos gânglios das metades cervical e torácica foi, respectivamente de $88,64 \%$ e $82,41 \%$ e no grupo $R, 84,62 \%$ da metade cervical e $75,43 \%$, da metade torácica.

\subsection{4 Área do perfil dos neurônios e gânglios reativos à NADPH-d}

A área do perfil neuronal do grupo $N$ variou de $293 \mu \mathrm{m}^{2}$ a $407 \mu \mathrm{m}^{2}$ (com média de $343,1 \pm 42,6 \mu \mathrm{m}^{2}$ ); de $119 \mu \mathrm{m}^{2}$ a $248,3 \mu \mathrm{m}^{2}$ (com média de 194,3 $\pm 52,6$ $\mu \mathrm{m}^{2}$ ) no grupo $D$ e de $167,5 \mu \mathrm{m}^{2}$ a $273,1 \mu \mathrm{m}^{2}$ (com média de $229,6 \pm 43,1 \mu \mathrm{m}^{2}$ ) no grupo $R$ (Figuras 48 e 49). 


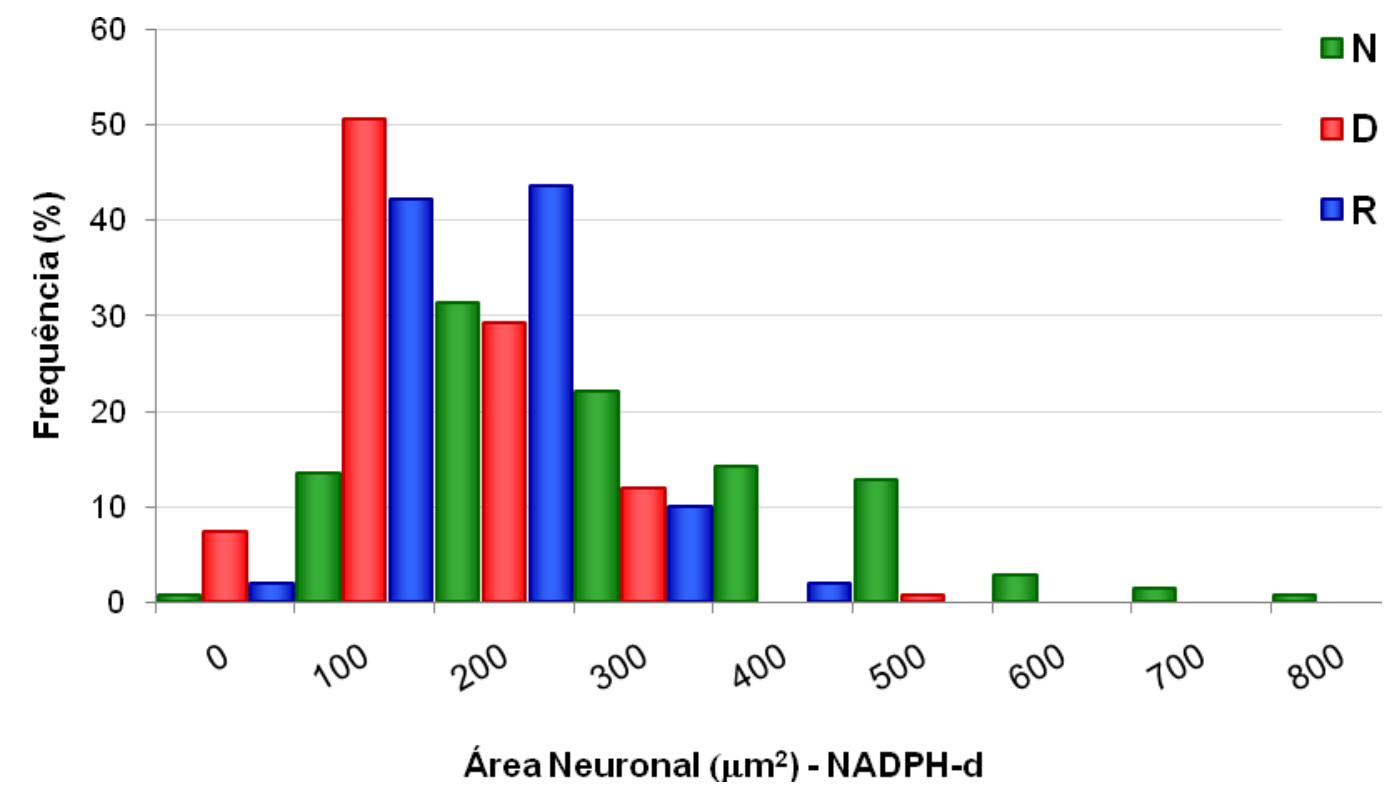

Figura 48 - Distribuição da área média do perfil celular NADPH-d reativos $\left(\mu m^{2}\right)$ nos grupos Nutrido (N), Desnutrido (D) e Renutrido (R).

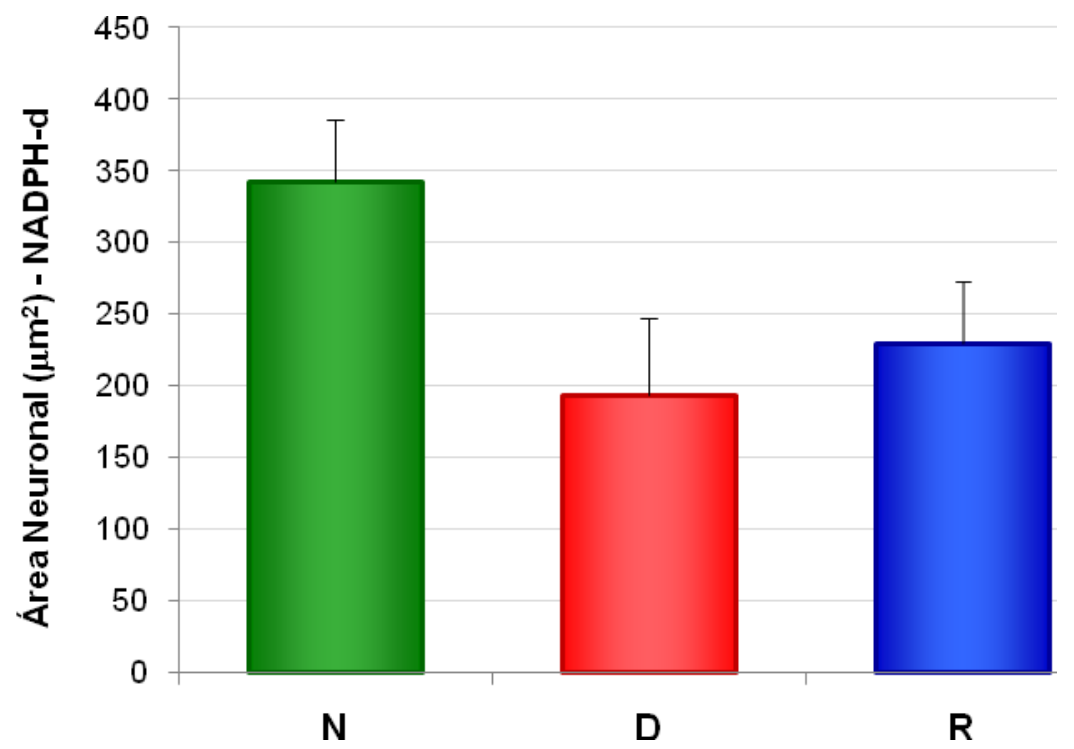

Figura 49 - Representação gráfica da média $( \pm D P)$ da área dos neurônios reativos à NADPH-d nos grupos Nutrido (N), Desnutrido (D) e Renutrido (R).

Ao se analisar os dados da figura 48, verificou-se que a maior concentração neuronal do grupo $\mathrm{N}$ encontra-se no intervalo de 200 a $300 \mu \mathrm{m}^{2}$, representando $31,4 \%$ dos neurônios; no grupo D, foram encontrados $50,6 \%$ dos neurônios no intervalo de 100 a $200 \mu^{2}$, sendo que para o grupo $R$, a maior concentração dos neurônios encontra-se no intervalo de 200 a $300 \mu \mathrm{m}^{2}$ com $43,6 \%$. 
Quanto às médias (Figura 49), foram observadas diferenças estatísticas entre todos os grupos $(p<0,001)$. Assim, os neurônios do grupo $N$ são maiores em relação aos neurônios dos grupos $\mathrm{D}$ e $\mathrm{R}$; quando estes são comparados entre si, os neurônios dos grupos $D$ e $R$ não diferiram entre si $(p>0,05)$.

A área do perfil ganglionar no grupo $N$ variou de $2224,4 \mu m^{2}$ a 3749,2 $\mu \mathrm{m}^{2}$ (com média de 2930,6 $\pm 742,5 \mu \mathrm{m}^{2}$ ), de $1340,8 \mu \mathrm{m}^{2}$ a $4026,4 \mu \mathrm{m}^{2}$ (com média de $2472,4 \pm 1022,9 \mu \mathrm{m}^{2}$ ) no grupo $D$ e de $1623,5 \mu \mathrm{m}^{2}$ a $4526,2 \mu \mathrm{m}^{2}$ (com média de $2960,7 \pm 1048,3 \mu \mathrm{m}^{2}$ ) no grupo $\mathrm{R}$ (Figuras 50 e 51).

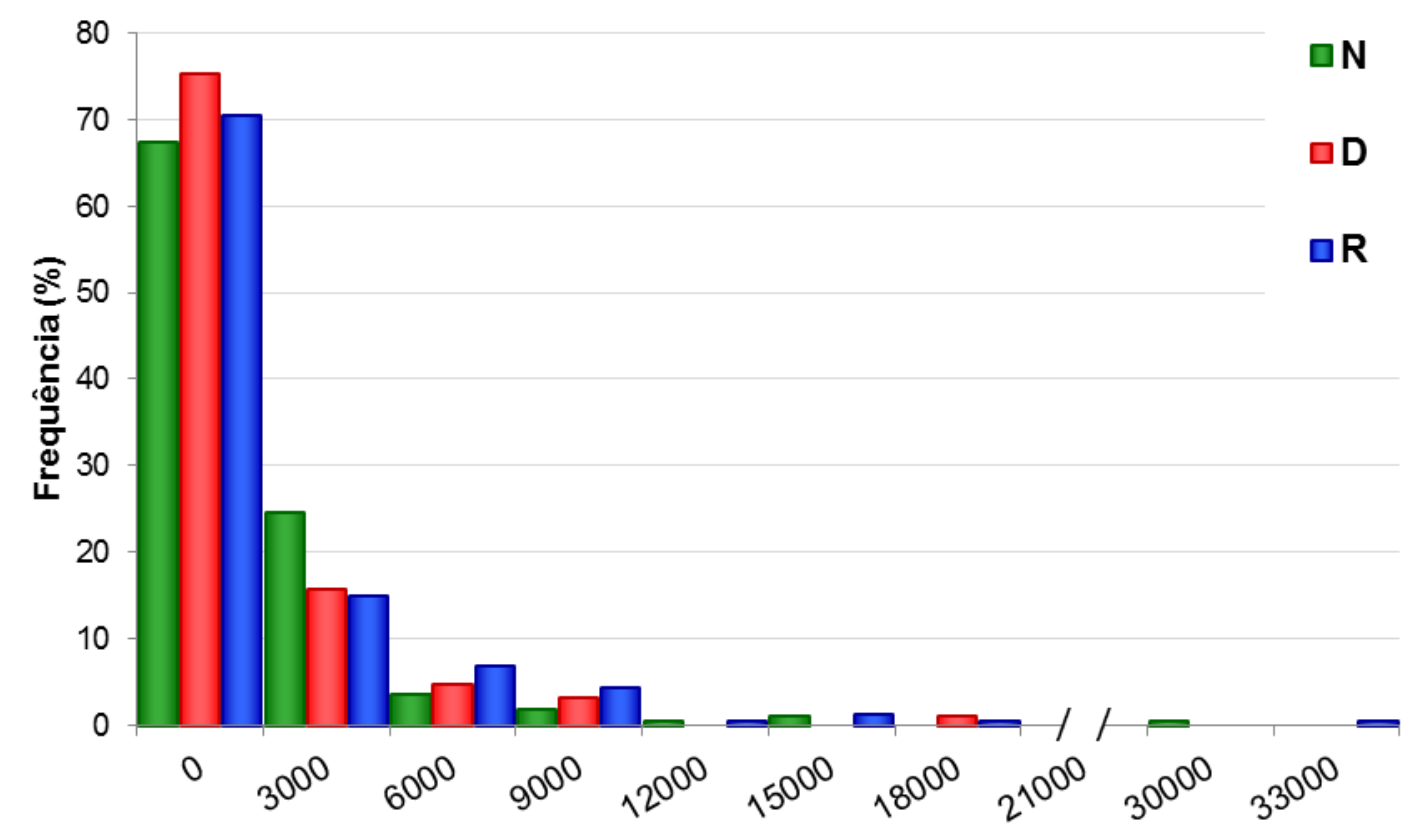

\section{Área Ganglionar $\left(\mu \mathrm{m}^{2}\right)$ - NADPH-d}

Figura 50 - Distribuição da área média do perfil ganglionar NADH-d reativos $\left(\mu m^{2}\right)$ nos grupos Nutrido (N), Desnutrido (D) e Renutrido $(R)$. 


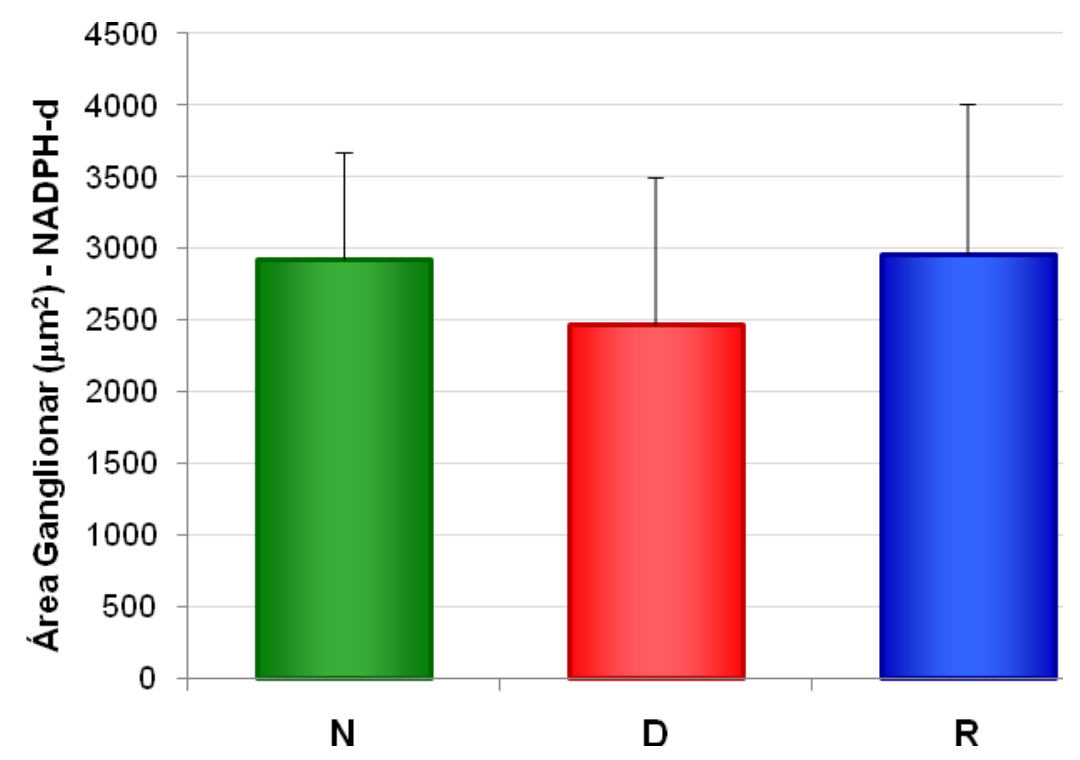

Figura 51 - Representação gráfica da média $( \pm D P)$ da área dos gânglios reativos à NADPH-d nos grupos Nutrido (N), Desnutrido (D) e Renutrido (R).

Ao se analisar os dados da figura 50 , verificou-se que a maior concentração ganglionar de todos os grupos ( $N, D$ e $R$ ) encontra-se no intervalo de 0 a $3000 \mu \mathrm{m}^{2}$, representando $67,49 \%$ dos gânglios do grupo $\mathrm{N}$ no grupo $D$, foram encontrados $75,26 \%$ dos gânglios sendo que para o grupo $R$ a maior concentração dos gânglios foi de $70,44 \%$.

Quanto às médias (Figura 51), não foram observadas diferenças estatísticas $(p=0,669)$ entre os gânglios de todos os grupos ( $N, D$ e R), sendo apenas verificado que o grupo $R$ apresentou a maior média e que o grupo $D$ apresentou a menor média.

Ao se avaliar entre os grupos ( $N, D$ e R), os dados referentes à área do perfil neuronal e ganglionar nas metades cervical e torácica da traquéia, foi possível verificar diferença significante entre os grupos $(p<0,001)$ em relação à área do perfil neuronal. Assim, os neurônios do grupo $\mathrm{N}$ são maiores em relação aos neurônios dos grupos $D$ e $R$; quando estes últimos são comparados, não se observa diferença significante, tanto na metade torácica quanto na metade cervical da traquéia. Ao se comparar as metades cervical e torácica, independente do fator grupo, observou-se diferença significante $(p<0,001)$, ou seja, os neurônios da metade torácica são maiores do que os neurônios da metade cervical (Figura 52). 


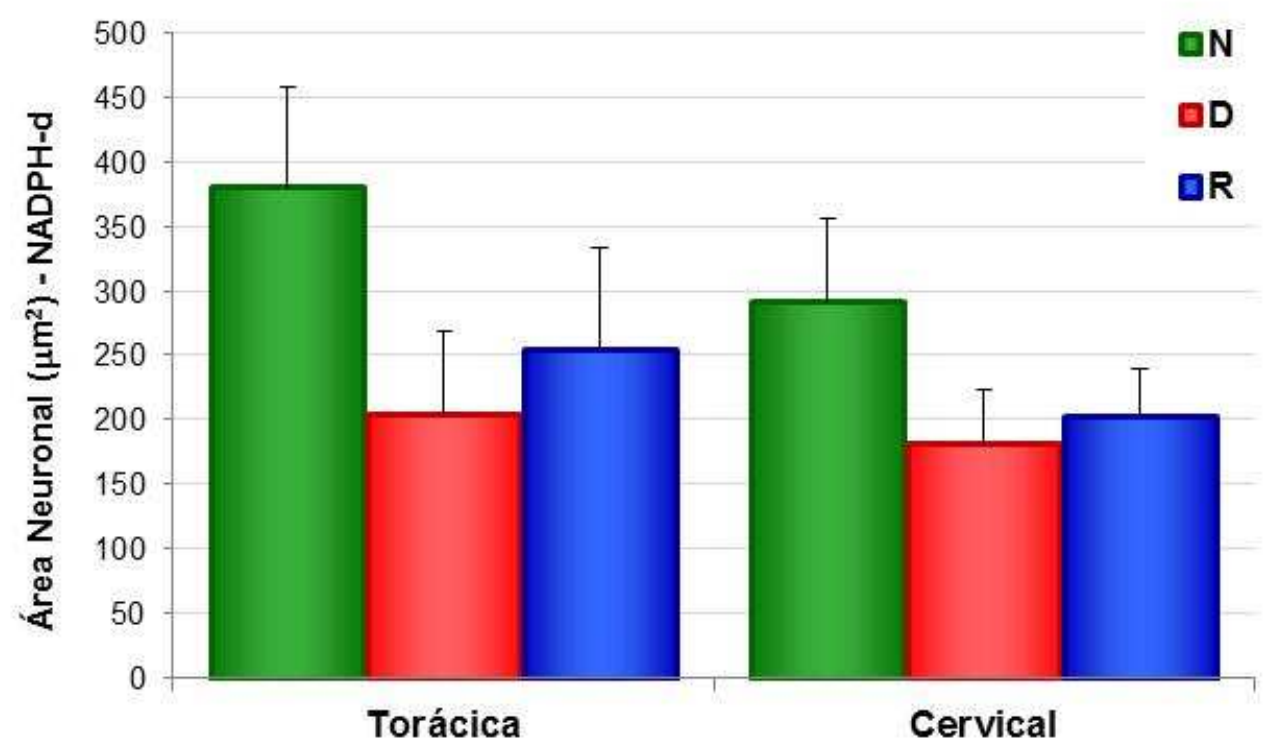

Figura 52 - Distribuição da área média $( \pm D P)$ de neurônios reativos à NADPH-d nas metades cervical e torácica nos grupos Nutrido $(N)$, Desnutrido (D) e Renutrido (R).

Na figura 53 estão expressos os dados referentes à distribuição da área do perfil neuronal nas metades cervical e torácica da traquéia.

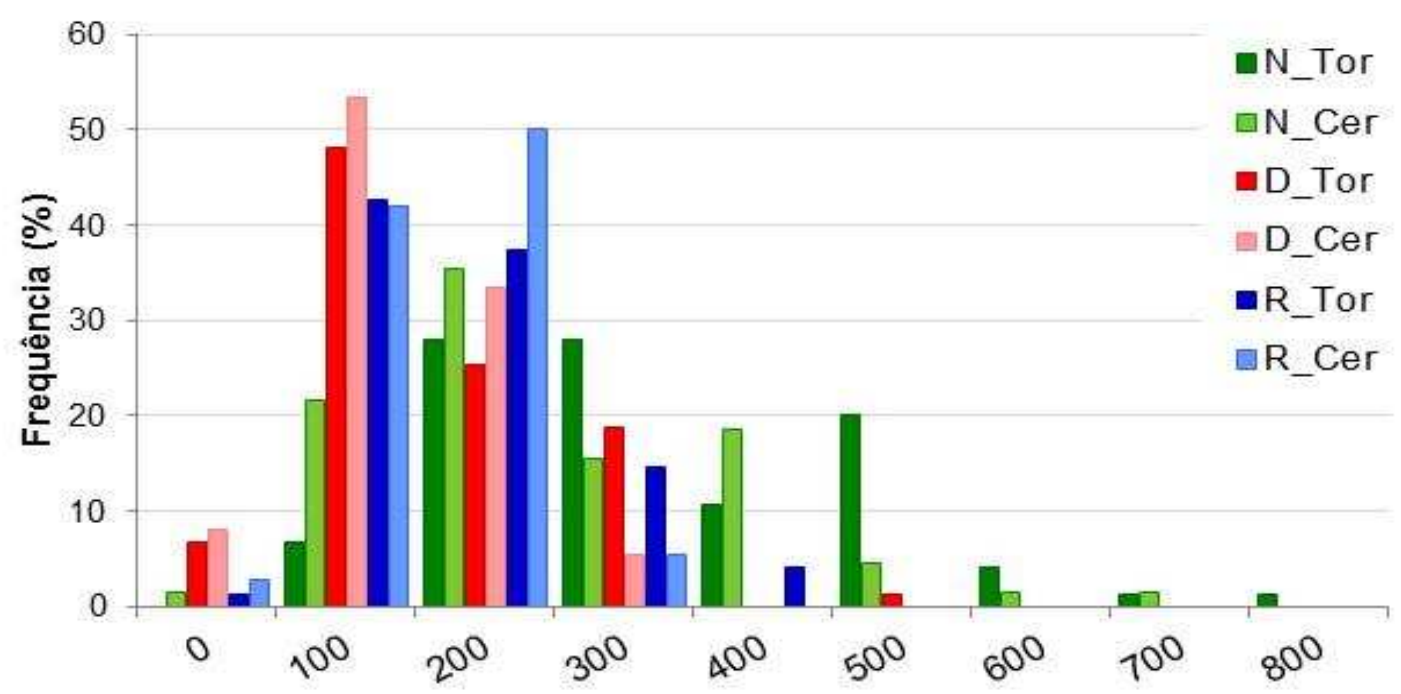

Área Neuronal $\left(\mu \mathrm{m}^{2}\right)$ - NADPH-d

Figura 53 - Distribuição da área média do perfil neuronal NADPH-d reativos $\left(\mu \mathrm{m}^{2}\right)$ nas metades cervical e torácica nos grupos Nutrido (N), Desnutrido (D) e Renutrido $(\mathrm{R})$.

A análise da figura permitiu verificar que, no grupo $N, 35,4 \%$ dos neurônios da metade cervical encontravam-se entre 200 e $300 \mu^{2}$ e $56 \%$ dos 
neurônios da metade torácica encontravam-se entre 200 e $400 \mu \mathrm{m}^{2}$, no grupo D, a concentração dos neurônios da metade cervical e torácica encontrava-se entre 100 e $200 \mu \mathrm{m}^{2}$ (53,3\% e 48\%, respectivamente) e no grupo $\mathrm{R}, 50 \%$ dos neurônios da metade cervical concentravam-se no intervalo entre 200 e 300 $\mu \mathrm{m}^{2}$ e $42,7 \%$ da metade torácica, no intervalo compreendido entre 100 e 200 $\mu m^{2}$.

Quando analisada a área do perfil ganglionar, não foi observada diferença significante entre os grupos $N, D$ e $R(p=0,809)$ (Figura 54). Ao se comparar as metades cervical e torácica, independente do fator grupo, observou-se diferença significante $(p<0,001)$, ou seja, os gânglios da metade torácica são maiores do que os gânglios da metade cervical.

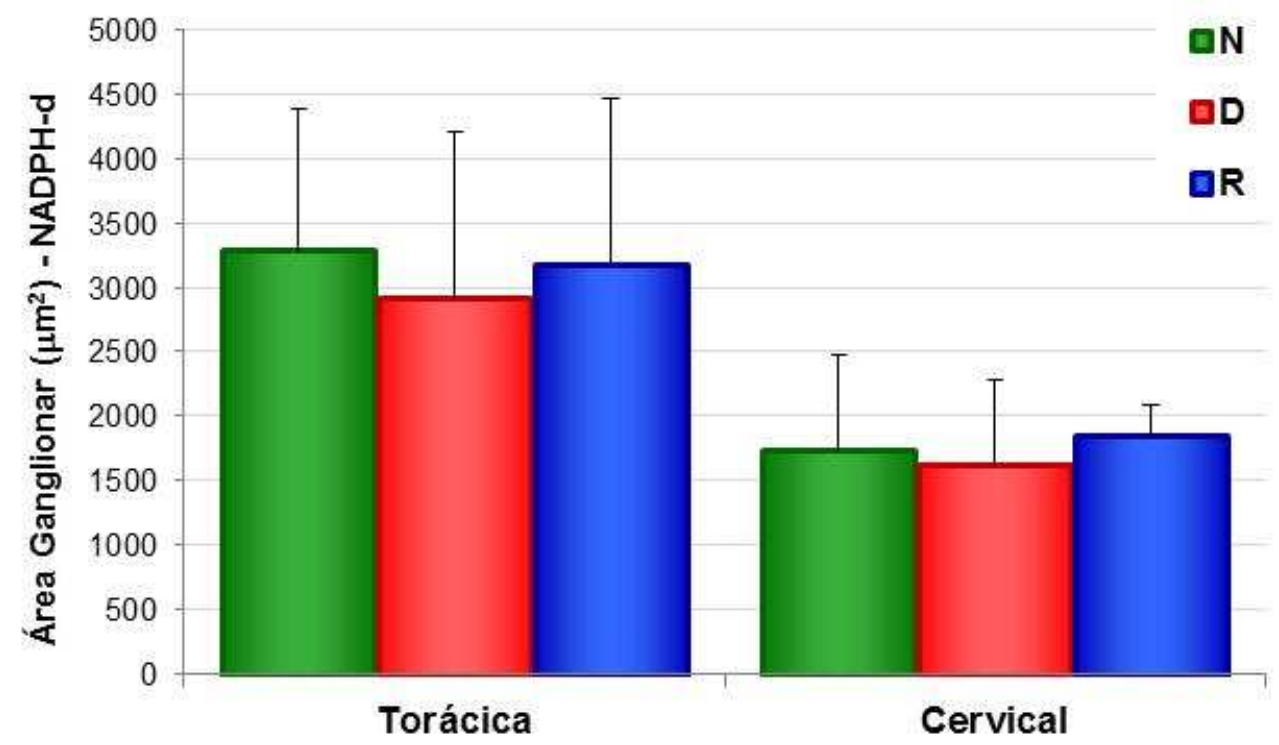

Figura 54 - Distribuição da área média $( \pm D P)$ dos gânglios reativos à NADPH-d nas metades cervical e torácica nos grupos Nutrido (N), Desnutrido (D) e Renutrido (R).

Na figura 55 estão expressos os dados referentes à distribuição da área do perfil ganglionar nas metades cervical e torácica da traquéia. 


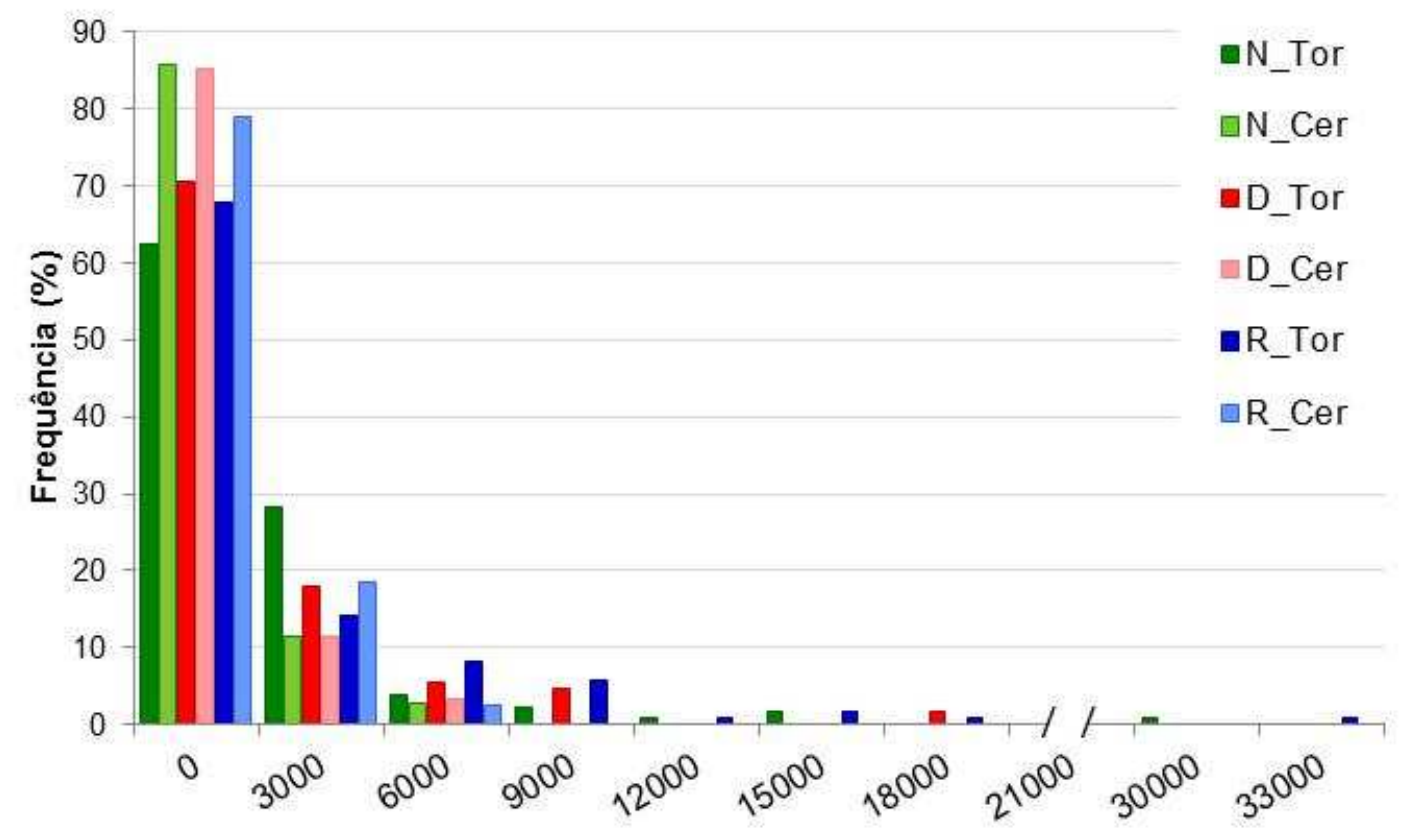

Área Ganglionar $\left(\mu \mathrm{m}^{2}\right)$ - NADPH-d

Figura 55 - Distribuição da área média do perfil ganglionar NADPH-d reativos $\left(\mu \mathrm{m}^{2}\right)$ nas metades cervical e torácica nos grupos Nutrido $(N)$, Desnutrido $(D)$ e Renutrido $(\mathrm{R})$.

Ao se analisar os dados acima, verificou-se que a maior concentração dos gânglios de todos os grupos (N, D e R) estavam no intervalo entre 0 e 3000 $\mu \mathrm{m}^{2}$, sendo assim, no grupo $\mathrm{N}$ verificou-se na metade cervical $85,71 \%$ e na metade torácica $62,51 \%$ dos seus gânglios. No grupo $D$, a maior concentração dos gânglios das metades cervical e torácica foi, respectivamente de $85,24 \%$ e $70,54 \%$ e no grupo $R, 78,95 \%$ da metade cervical e $67,77 \%$, da metade torácica. 
5 DISCUSSÃO 


\subsection{Aspectos gerais sobre a desnutrição}

O crescimento normal é dependente de inúmeros processos fisiológicos que precisam do atendimento de várias necessidades durante a vida fetal e a infância. A marcante vulnerabilidade das crianças faz com que seu crescimento constitua um excelente indicador na avaliação de saúde e do desenvolvimento socioeconômico da comunidade onde elas vivem (VICTORA; ARAÚJO; DE ONIS, 2007).

Uma vez, que ainda sejam necessários mais esclarecimentos acerca da desnutrição severa, já que se trata de uma síndrome sistêmica e complexa, compreende-se que, o modelo nutricional empregado nesta pesquisa reflete a situação apresentada em países em desenvolvimento. Alterações morfofuncionais importantes, que podem ser avaliadas decorrentes dos diferentes processos de desnutrição, tornam os modelos experimentais apropriados para o esclarecimento destas questões (PICHARD, 1997; BAPTISTA, 2008).

$\mathrm{Na}$ tentativa de esclarecer alguns destes apontamentos observou-se que o desenvolvimento corporal apresentado pelos animais dos três grupos (N, D e $R$ ), tanto no que se refere ao peso corporal quanto ao comprimento, foi marcante a diferença apresentada pelos animas do grupo $D$, em relação aos dos grupos $\mathrm{N}$ e $\mathrm{R}$, uma observação facilmente realizada à vista desarmada, onde os animais desnutridos exibiram um tamanho significativamente menor. $O$ mesmo não se pode aplicar ao se comparar os animais dos grupos $\mathrm{N}$ e $\mathrm{R}$, onde, apesar de se verificar diferença entre o seu peso corporal, o comprimento dos mesmos se mostrou muito semelhante (Figura 4).

Esses dados sugerem que o período de 42 dias, foi suficiente para promover alterações importantes nos animais do grupo $D$.

Esses resultados corroboram com trabalhos que avaliaram o peso corporal de ratos submetidos ao mesmo protocolo de desnutrição protéica, sendo observadas diferenças significantes entre os animais nutridos e os animais desnutridos e recuperados (ou renutridos) (CASTELUCCI et al., 2002a; GOMES et al., 2006; OLIVEIRA, 2006; MISAWA, 2007).

Os dados da presente pesquisa vão ao encontro daqueles observados por Sawaya (2006), que, após análise da recuperação nutricional de crianças 
desnutridas, relataram que o ganho de comprimento ocorre mais rapidamente, enquanto que, o ganho de peso, juntamente com a densidade mineral óssea, ocorrem de maneira mais lenta mas que, com os cuidados necessários, alcançam os valores de normalidade.

Os dados relativos ao peso corporal aplicam-se também ao órgão alvo da presente pesquisa, ou seja, a traquéia. Sendo assim, a comparação do peso da víscera dos animais do grupo $\mathrm{D}$ com o dos grupos $\mathrm{N}$ e $\mathrm{R}$, deixa evidente que a carência protéica determinou alterações relevantes durante o período estudado. A média do peso traqueal dos animais do grupo $D$ representou apenas $22 \%$ do peso traqueal do grupo N, e mesmo a média do peso traqueal dos animais do grupo $R$ sendo maior que a dos animais do grupo $D$, representou apenas $52 \%$ da média dos animais do grupo $\mathrm{N}$.

A avaliação da razão peso traqueal/corporal não identificou diferenças entre os grupos N e D. Ao invés do observado para o peso corporal e traqueal, a média do grupo $\mathrm{R}$ foi a menor; assim, não se descarta a hipótese de que a desnutrição protéica, em determinados períodos, seja responsável por alterações irrecuperáveis em curto prazo, pois, a cobaia mesmo com 0 reestabelecimento da nutrição normoprotéica dos 22 até os 42 dias, a mesma não foi capaz de promover o desenvolvimento do peso traqueal tanto quanto foi observado para o peso corporal. Porém, ao avaliar os efeitos da renutrição em longo prazo, estudos com ratos renutridos até 60 dias (BAPTISTA, 2008) e crianças desnutridas acompanhadas até a adolescência (SAWAYA, 2006) descrevem uma recuperação satisfatória, tendo os valores retornados aos parâmetros da normalidade.

\subsection{Características gerais do plexo traqueal de ratos}

Os dois troncos nervosos longitudinais principais que foram verificados sobre a musculatura da traquéia continuando-se nos brônquios principais e lobares, e a presença de gânglios interconectados a esses feixes nervosos corroboram com as descrições desse plexo na maioria dos mamíferos de pequeno porte, como o camundongo (CHIANG; GABELLA, 1986), o Calomys callosus (FURLANI et al., 2008), o rato (CHIANG, 1993), a cobaia (BALUK; 
GABELLA, 1989a) e o furão (BAKER et al., 1986). Todavia, suas características são diferentes das observadas em animais de maior porte, como o gato (KUDER et al., 2003) e o cão (YAMAMOTO et al., 1998), onde se descreve um denso emaranhado de feixes nervosos, sem os troncos principais. Semelhanças com esse tipo de animal podem ser referidas quanto à distribuição difusa dos gânglios na malha (YAMAMOTO et al., 1998). Todavia, não se pode concordar com esse autor ao descrever a aleatoriedade da distribuição desses gânglios, uma vez que se comprovou, na presente pesquisa, que a maior concentração dessas estruturas foi encontrada na metade torácica do órgão, local onde, também, ocorreu a maior densidade das malhas nervosas. Comparativamente, esses resultados acerca das malhas estão de acordo com as descrições de Chiang (1993) que, ao ressaltar pormenores sobre os feixes nervosos das malhas do plexo traqueal de ratos verificou que, aqueles da metade torácica são mais espessos e maiores que os da metade cervical.

Relativamente à organização geral do plexo traqueal, não se verificou uma uniformização no padrão de distribuição de seus componentes, como aquela existente no plexo mioentérico a qual, dependendo dos efeitos do agente sobre a sua estrutura como a desnutrição (BRANDÃO et al., 2003), o envelhecimento (DE SOUZA et al., 1993), o mal de Chagas (MAIFRINO et al., 1999) ou a lesão térmica corporal (SEYFERT, 2009), pode ser alterada e facilmente detectada. Todavia, com os resultados aqui obtidos, não se pode afirmar que, a desnutrição tenha promovido uma alteração na conformação geral do plexo, uma vez que, o mesmo padrão foi apresentado em todos os grupos experimentais (N, D e R).

\subsection{Morfologia dos neurônios e gânglios}

Dentre as diferentes metodologias empregadas na descrição dos constituintes do plexo traqueal destacam-se as técnicas histoquímicas da $\mathrm{NADH}-\mathrm{d}$ e AChE, amplamente utilizadas na evidenciação de outros plexos parassimpáticos (CHIANG; GABELLA, 1986; DE SOUZA et al., 1996; 
MAIFRINO et al., 1999; ROLLE et al., 2002; KUDER et al., 2003; FURLANI et al., 2008).

Desta forma, através dessas técnicas foi possível observar que, de um modo geral, os neurônios e gânglios constituintes do plexo traqueal de todos os grupos (N, D e R) apresentaram, basicamente, a mesma morfologia, ou seja, gânglios de formato e tamanho irregulares e neurônios com aspecto predominantemente circular, ovoide ou alongado, não se notando predomínio aparente de nenhum formato em todos os grupos estudados. Essa observação está de acordo com o descrito por Castelucci et al. (2002a), que, ao avaliar a morfologia dos neurônios constituintes do plexo mioentérico do intestino grosso de ratos submetidos à desnutrição protéica, não encontraram diferenças passíveis de determinar o grupo estudado. Da mesma forma, Furlani et al. (2008) descreveram a mesma morfologia nos gânglios e neurônios do plexo traqueal de Calomys callosus infectados pelo Trypanosoma cruzi e seus respectivos controles. Pelo exposto, sugere-se que, alterações sistêmicas determinadas por diferentes agentes não alteram, significativamente, a morfologia dos gânglios e neurônios do plexo traqueal.

$A$ intensidade de reação dos neurônios do plexo traqueal às técnicas histoquímicas NADPH-d e AChE apresentou-se, extremamente, variável nos diferentes grupos ( $N, D$ e R). Com relação aos neurônios nitrérgicos, destacase que, em um mesmo gânglio, a maior parte da população neuronal exibiu intensa reatividade, porém, neurônios com moderada ou fraca reatividade também foram observados, além de amplos espaços indicativos da presença de neurônios não nitrérgicos.

Ao avaliar o plexo mioentérico do jejuno de ratos expostos à lesão térmica corporal, Seyfert (2009) descreve uma ampla variação na intensidade de reação tanto no grupo controle, quanto no grupo exposto. $O$ autor enfatiza que apesar da heterogeneidade na reatividade dos corpos neuronais, o grupo exposto à lesão apresentou grande parte dos seus neurônios com intensa reatividade. Também uma ampla variedade de intensidade foi encontrada por Gréggio et al. (2010) no plexo esofágico de ratos submetidos ao mesmo protocolo da presente pesquisa. Os autores identificaram na característica da intensidade de reação dos corpos neuronais, uma das características palpáveis para a determinação dos grupos estudados, porquanto, os corpos neuronais 
dos animais nutridos apresentaram intensa reatividade, enquanto que, aqueles presentes no plexo do grupo desnutrido apresentaram fraca intensidade; por sua vez, a maioria dos neurônios do grupo recuperado (ou renutrido) demonstrou predomínio de uma reatividade moderada.

Diferentemente dos dados aqui apresentados para o grupo nutrido, considerado o controle (ou normal), Andreeva, Shumatova e Motavkin (2000) após avaliarem o plexo traqueal normal de ratos e humanos, observaram fraca reatividade para os neurônios nitrérgicos.

Os resultados, tanto da presente pesquisa como os das previamente citadas, devem ser analisados com cautela, uma vez que, a intensidade de reação pode estar associada ao tempo em que se expõe o tecido ao reagente. Assim, revelando preocupação com esse tema, autores como Cserni et al. (2009), Kuo et al. (1994) e Montedonico et al. (2006), ao utilizarem a técnica histoquímica da NADPH-d para avaliarem os aspectos morfoquantitativos do plexo mioentérico, em estudos experimentais e neuropatologias humanas demostraram, por meio de diferentes tempos de incubação, que a determinação da intensidade de reação e da população neuronal é diretamente proporcional ao tempo de exposição.

Talvez seja este um fato a ser considerado quando se comparou os dados da presente pesquisa com aqueles de Andreeva, Shumatova e Motavkin (2000), uma vez que, os espécimes por eles utilizados permaneceram apenas 1 hora expostos ao reagente, ou seja, metade do tempo aqui utilizado. Outra hipótese que não deve ser descartada, é o fato de um mesmo neurônio poder desempenhar, no plexo traqueal, duas ou mais funções, o que pode ser detectado utilizando-se técnicas de dupla marcação ou colocalização de corpos neuronais do plexo traqueal, como demonstrado por Kusindarta, Atoji e Yamamoto (2004).

A intensidade da reatividade dos neurônios do plexo traqueal à técnica da AChE aqui avaliada permitiu estabelecer que, nos grupos $\mathrm{N}$ e $\mathrm{R}$, a maioria dos neurônios eram intensamente reativos, com poucos neurônios fracamente reativos, ocorrendo o inverso para o grupo $D$, ou seja, a maioria dos neurônios fracamente reativos, com a presença de poucos neurônios intensamente reativos. 
Nos trabalhos que utilizaram a técnica da AChE para a determinação do padrão de distribuição dos gânglios do plexo traqueal (CHIANG, 1993; KUDER et al., 2003; FURLANI et al., 2008), não foram feitas referências acerca da intensidade de reação dos neurônios. Todavia, tais observações foram realizadas em trabalhos sobre o plexo mioentérico de ratos, empregando-se o mesmo protocolo de desnutrição da presente pesquisa. Tanto no intestino grosso de ratos (CASTELUCCI, 1999) como no esôfago (GRÉGGIO et al., 2010) detectou-se intensa reatividade nos neurônios dos animais nutridos e renutridos, e o predomínio de fraca reatividade nos neurônios dos animais desnutridos, fato este, que corrobora com o que foi aqui identificado. Assim, independentemente da víscera, pode-se inferir que, a desnutrição altera a atividade metabólica dos neurônios dos diferentes tipos de plexo, atividade esta, que se verifica voltar aos parâmetros normais, quando da recuperação protéica. Essa análise pode ser fundamentada pelas observações de Adlard e Dobbing (1971), que, ao observarem a diminuição da atividade do metabolismo do sistema neurotransmissor colinérgico dos animais desnutridos, relacionaram-na ao fato dos neurônios destes animais apresentarem fraca reatividade à $\mathrm{AChE}$.

Com relação às técnicas para $S P$ verificou-se em todos os grupos $(N, D$ e R) que poucos neurônios, e de tamanho pequeno, eram intensamente imunorreativos. O mesmo pode-se afirmar para a técnica do VIP para os animais $\mathrm{N}$ e $\mathrm{R}$; porém, no grupo $\mathrm{D}$ foram detectados somente neurônios fracamente imunorreativos.

Avaliando o plexo traqueal de ratos, Kusindarta, Atoji e Yamamoto (2004) descrevem resultados, em parte semelhantes, uma vez que, observaram poucos neurônios imunorreativos ao VIP, entretanto, não encontraram neurônios imunorreativos à SP, os quais foram detectados no plexo traqueal da cobaia por Canning et al. (2002) e no plexo traqueal do furão, por Wu e Dey (2006). Relativamente à imunorreatividade à SP e ao VIP, trabalho de Eustáquio-Silva (2010), embora realizado no gânglio trigeminal de ratos jovens, apresenta resultados muito semelhantes ao observado na presente pesquisa, ou seja, somente os neurônios de tamanho pequeno exibiram intensa imunorreatividade. 
Avaliando-se tais resultados, verifica-se que a intensa imunorreatividade ocorre, preferencialmente, em neurônios de tamanho pequeno, não sendo uma condição que possa estar relacionada à desnutrição ou a um determinado grupamento de neurônios (seja ele um plexo ou um gânglio) uma vez que, esse aspecto ocorreu mesmo em animais jovens e normais, como no caso do gânglio trigeminal. O que se pode correlacionar com o estado nutricional, é o fato dos neurônios não terem expressado imunorreatividade ao VIP nos animais do grupo $D$, o que não significa que animais desnutridos com mais idade não possam vir a expressá-la, uma vez que, como se sabe, a desnutrição promove um atraso no desenvolvimento de diferentes tecidos e, dentre os neurônios do plexo, pode ser que aqueles que expressam a SP amadureçam em um período anterior àqueles vipérgicos.

Sob o aspecto tridimensional verificado à luz da MEV, a organização dos feixes nervosos em malhas de diferentes tamanhos, o aspecto dos gânglios $e$ dos neurônios estão de acordo com as observações de (BALUK; FUJIWARA; MATSUDA, 1985) no plexo traqueal da cobaia. Assim, independentemente do animal, é nítida a semelhança estrutural nesses mamíferos de pequeno porte, bem como, em muito se assemelham os aspectos tridimensionais do plexo da veia pulmonar de camundongos descritos por Baluk e Gabella (1987).

\subsection{Considerações acerca da morfometria}

A técnica histoquímica da NADH-d tem sido, amplamente, utilizada em nosso meio no estudo das características morfométricas dos componentes de diferentes plexos nervosos como o plexo mioentérico, do colo (CASTELUCCI et al., 2002a), do intestino delgado (BRANDÃO et al., 2003), do esôfago (LIBERTI et al., 2007); o plexo cardíaco (AKAMATSU et al., 1999; MAIFRINO et al., 2006) e o plexo traqueal (CHIANG; GABELLA, 1986; FURLANI et al., 2008). Do mesmo modo, a técnica da NADPH-d tem sido utilizada para avaliar quantitativamente os neurônios nitrérgicos do plexo mioentérico do esôfago (GRÉGGIO et al., 2010), do intestino grosso (FONTES et al., 2004), e o plexo cardíaco (AKAMATSU, 2006). Todavia, até o presente, não se teve acesso na literatura a pesquisa que tenham avaliado os aspectos morfométricos dos 
neurônios nitrérgicos no plexo traqueal, que permitam comparações com os dados aqui apresentados. Desta forma, pode-se considerar que a traquéia de ratos apresenta, em média, 270 neurônios reativos à NADPH-d (mínimo de 215 e máximo de 320).

Relativamente à técnica da NADH-d, muito embora tenham sido detectados espaços no interior dos gânglios dos animais desnutridos (o que poderia representar um indicativo de perda neuronal), não foram observadas diferenças significativas entre os grupos estudados ( $N, D$ e $R$ ) quanto ao número de gânglios e neurônios. Castelucci et al. (2002a) ao avaliarem o plexo mioentérico do intestino grosso de ratos nutridos, desnutridos e renutridos, com o mesmo período estudado na presente pesquisa, também não identificaram diferenças quanto ao número de neurônios entre os grupos, o que permite inferir que, a desnutrição não diminui o número de neurônios, pelo menos na fase abordada (42 dias).

Nos mamíferos em geral, o número de corpos neuronais e gânglios no plexo traqueal é bastante diversificado, tendo sido descrito cerca de 18.461 neurônios e 2389 gânglios no cão (YAMAMOTO et al., 1998), de 95 a 210 gânglios no gato (KUDER et al., 2003), 2.577 neurônios e 920 gânglios no furão (BAKER et al., 1986), 222 neurônios na cobaia (BALUK; GABELLA, 1989b), 549 neurônios e 70 gânglios (CHIANG, 1993) e 749 neurônios e 84 gânglios (KUSINDARTA; ATOJI; YAMAMOTO, 2004) no rato, 279 neurônios e 18 gânglios no Calomys callosus (FURLANI et al., 2008) e 235 neurônios e 14 gânglios no camundongo (CHIANG; GABELLA, 1986). No presente estudo, foram encontrados, em média, 265 neurônios e 34 gânglios, número menor do que citado por Chiang (1993) e Kusindarta, Atoji e Yamamoto (2004).

O número elevado de neurônios e gânglios no plexo traqueal dos animais, de porte semelhante a cães e gatos, reflete uma inervação mais complexa. Entre os animais de pequeno porte, os dados de Chiang e Gabella (1986) para o camundongo e de Furlani et al. (2008) para o Calomys callosus são semelhantes aos observados na presente pesquisa, com ratos de 42 dias de vida; representando porém cerca da metade do descrito por Chiang (1993) e Kusindarta, Atoji e Yamamoto (2004), para o rato. Vale ressaltar que Chiang (1993) utilizou ratos machos e fêmeas com o mesmo peso (180g), porém, não com a mesma idade, uma vez que, as fêmeas exibem um peso sempre abaixo 
dos machos de idade correspondente. Além disso, o autor não especifica o número de animais machos e de animais fêmeas o que, de certa forma, dificulta estabelecer-se uma comparação com os resultados obtidos na presente pesquisa. De qualquer forma, o número por ele observado (estabelecido com o uso da técnica da AChE) é muito superior aos dados aqui expostos, obtidos através da técnica da NADH-d (muito embora se tenha aplicado no presente trabalho tal metodologia, seus resultados foram apenas qualitativos). Apesar de terem utilizado ratos machos, os números elevados de neurônios e de gânglios descritos por Kusindarta, Atoji, Yamamoto (2004) talvez, possam ser explicados pela diferença de idade e de peso entre os seus animais e os da presente pesquisa ( $270 \mathrm{~g}$ e 82 dias de vida, versus $150 \mathrm{~g}$ e 42 dias de vida) e, mais ainda, pelo fato de os autores terem computado também os neurônios presentes nos brônquios principais.

O fato do número total de neurônios e gânglios obtidos ser, praticamente, o mesmo número dos neurônios e gânglios nitrérgicos (265 neurônios e 34 gânglios reativos à NADH-d e 276 neurônios e 34 gânglios reativos à NADPH-d) pode ser explicado com as considerações realizadas por Kohn et al. (2010) sobre o sistema respiratório. Esses autores descrevem que, a alta população de neurônios nitrérgicos constituintes do plexo traqueal de humanos (desde recém-nascidos até o final da infância) e de alguns modelos experimentais (entre eles, o rato), tem por finalidade auxiliar para que as vias aéreas mantenham-se patentes, uma vez que, ocorre uma alta incidência de eventos obstrutivos nas mesmas causadas pelo seu pequeno calibre, inflamação recorrente, alterada função dos neurotransmissores e ao alto risco de hiper-reatividade das vias, sendo tais eventos, admitidos como característicos clássicos da asma. Deste modo, a grande população de neurônios nitrérgicos pode ser explicada devido às funções que exercem em várias células do sistema respiratório, sendo a mais importante, a promoção do relaxamento da musculatura lisa com consequente dilatação dos brônquios (GUEMBE; VILLARO, 1999; ANDREEVA; SHUMATOVA; MOTAVKIN, 2000; NADEEM et al., 2009).

Nos animais controle (grupo $\mathrm{N}$ ) da presente pesquisa verificou-se uma média de 7,6 neurônios por gânglio reativos à $\mathrm{NADH}-\mathrm{d}$, uma relação muito similar àquela observada por Chiang (1993) no rato (aproximadamente 8 
neurônios por gânglio) e por Yamamoto et al. (1998) no cão (cerca de 7,7 neurônios por gânglio), porém, bem abaixo dos 17 neurônios por gânglio encontrados por Chiang e Gabella (1986) no plexo traqueal dos camundongos. A média de neurônios por gânglio, para os animais do grupo $D$, foi elevada $(10,1)$, sendo a menor entre os grupos estudados, aquela verificada para os animais renutridos (grupo R). Esses dados reforçam a teoria de que, a desnutrição atrasa o desenvolvimento de diversas estruturas do organismo, o que parece ser um fato também para o plexo traqueal, uma vez que, como tem sido descrito para o plexo mioentérico, os neurônios redundantes ainda não foram eliminados nos animais desnutridos, fato provavelmente ocorrido com os animais nutridos, já nessa fase da vida do animal.

A área média do perfil dos neurônios ganglionares dos animais do grupo $\mathrm{N}$, marcados pela $\mathrm{NADH}-\mathrm{d}$ foi de $455,6 \mu \mathrm{m}^{2}$, foram comparativamente menor do que a de $523 \mu \mathrm{m}^{2}$ verificada para o cão (YAMAMOTO et al., 1998), semelhante à de $474 \mu \mathrm{m}^{2}$ (CHIANG, 1993) e maior do que a de $309 \mu \mathrm{m}^{2}$ (KUSINDARTA; ATOJI; YAMAMOTO, 2004) observadas no rato e maior do que aquela de $251 \mu^{2}$ descrita para o camundongo (CHIANG; GABELLA, 1986). Esses dados demonstram que, as diferenças existentes entre as espécies podem estar relacionadas ao tamanho do corpo do animal e que, a média menor verificada por, Kusindarta, Atoji e Yamamoto (2004) para o rato, provavelmente, se deva ao fato de terem computado também os neurônios brônquicos que, na presente pesquisa, muito embora não tenham sido mensurados, aparentaram ser menores do que aqueles presentes na traquéia. Essa afirmação pode ser embasada por Baker et al. (1986) que, ao avaliarem o plexo traqueal do furão lançaram a hipótese de que, os diferentes tamanhos de neurônios podem estar relacionados à sua posição no plexo traqueal, uma vez que, observaram que o tamanho dos neurônios ganglionares do tronco principal são maiores do que aqueles presentes na superfície (plexo superficial muscular).

As áreas médias do perfil dos neurônios ganglionares, respectivamente dos animais dos grupos $\mathrm{D}$ e $\mathrm{R}\left(146 \mu \mathrm{m}^{2}\right.$ e $\left.268,8 \mu \mathrm{m}^{2}\right)$, permitem inferir que, a desnutrição diminui esse parâmetro e que a renutrição não foi capaz de restabelecer o tamanho dos neurônios do plexo traqueal, pelo menos no período estudado. Muito embora, comparativamente à NADH-d, a área dos 
neurônios nitrérgicos tenha se apresentado menor nos grupos $N$, D e R (respectivamente $343 \mu \mathrm{m}^{2}, 194,3 \mu \mathrm{m}^{2}$ e 229,6 $\mu^{2}$ ), essa proporção quanto ao estado nutricional se mantém, o que leva a crer que, a desnutrição também afeta esse tipo de neurônio.

No intestino grosso (CASTELUCCI et al., 2002a) e delgado (BRANDÃO et al., 2003) de ratos denutridos, foram observados dados semelhantes aos aqui obtidos, ou seja, com a submissão dos animais à desnutrição, ocorreu a diminuição do perfil neuronal, e com a recuperação protéica, os neurônios apresentaram em algum grau, um aumento do seu perfil neuronal; entretanto, sem alcançar os valores observados no grupo controle (animais nutridos).

Não foram encontrados, pelo menos na literatura consultada, dados acerca do perfil dos gânglios do plexo traqueal, que pudessem ser confrontados com os aqui descritos. Todavia, é oportuno comentar-se que, também para essa variável, os gânglios evidenciados pela técnica da NADH-d são maiores nos animais nutridos $\left(4595,1 \mu \mathrm{m}^{2}\right)$, menores nos animais desnutridos $\left(2007 \mu^{2}\right)$ e, parcialmente, recuperados nos animais renutridos $\left(2555,6 \mu \mathrm{m}^{2}\right)$. Todavia, chama à atenção o fato de, não terem sido detectadas diferenças estatisticamente significativas entre os grupos, quando se avaliou a área dos gânglios reativos à NADPH-d $\left(\mathrm{N}=2930,6 \mu \mathrm{m}^{2} ; \mathrm{D}=2472,4 \mu^{2}\right.$; $\mathrm{R}=2960,7 \mu \mathrm{m}^{2}$ ). Estabelecer uma proporção entre os neurônios pequenos, médios e grandes em todos os grupos, talvez possa ajudar a elucidar esses fatos.

\subsection{Aspectos quantitativos entre as metades da traquéia}

As metades cervical e torácica da traquéia exibiram características próprias quando esse item foi avaliado. De fato, a distribuição heterogênea dos constituintes do plexo já havia sido descrita no furão (BAKER et al., 1986), no camundongo (CHIANG; GABELLA, 1986), no rato (CHIANG, 1993), no cão (YAMAMOTO et al., 1998) e, novamente, no rato (KUSINDARTA; ATOJI; YAMAMOTO, 2004).

Assim, após a análise das metades torácica e cervical, verificou-se que, em torno de $80 \%$ do número total de neurônios e gânglios estavam situados na 
metade torácica, o que concorda com as descrições de Chiang (1993), que ao avaliar o padrão do plexo traqueal de ratos, descreveu a distribuição de $86 \%$ dos constituintes do plexo traqueal localizados na metade torácica, apontando como motivo provável para essa distribuição desigual de neurônios e gânglios, o maior volume da musculatura na metade torácica do órgão.

Krishnan, Pal e Boradkar (1982) e Mizuno (2010), ao estudarem, respectivamente, o plexo mioentérico do intestino delgado de ratos e de camundongos corroboram com essa hipótese, ao afirmarem que, a maior concentração de gânglios e neurônios em determinadas regiões está, diretamente, relacionada ao aumento da demanda funcional do órgão.

A concentração aumentada de neurônios por gânglio da metade torácica é outro fator que demonstra o quanto esta hipótese, relacionada ao aumento de função em determinada região, determina a distribuição dos neurônios sobre toda a extensão da musculatura traqueal.

Essas assertivas aplicam-se à traquéia, uma vez que, Kondo et al. (2000) sugerem que o aumento da concentração de corpos neuronais, e consequente aumento do número de gânglios próximos a bifurcação traqueal, promove à região, uma sensibilidade maior, quando comparada com a região do órgão onde há uma diminuição do número de neurônios.

Ainda com relação a essa divisão, de um modo geral, observou-se que na quase totalidade dos casos, os gânglios e neurônios da metade torácica de todos os grupos estudados ( $N$, D e R) eram maiores do que aqueles da metade cervical, o que se supõem estar relacionado à quantidade de tecido inervado. Tais observações têm apoio nas descrições de Gabella (1987) ao verificar um aumento na densidade e no perfil neuronal do plexo mioentérico do intestino delgado de camundongo, cobaia e ovelha, de acordo com a demanda funcional do órgão. 
6 CONCLUSÕES 
De acordo com a metodologia empregada e os resultados ora apresentados acerca das repercussões morfológicas determinadas pela desnutrição nos constituintes do plexo traqueal, é lícito concluir-se que:

1. O peso corporal, assim como o peso traqueal dos animais do grupo $\mathbf{N}$ apresentou a maior média sendo a dos animais do grupo $\mathrm{D}$ a menor, enquanto que os animais do grupo $R$ apresentaram valores intermediários;

2. A razão peso traqueal/peso corporal foi menor no grupo $R$, devido ao atraso no desenvolvimento em geral, ocasionado pelo período de desnutrição até a época do desmame;

3. Em todos os grupos o plexo traqueal exibiu dois troncos nervosos principais, apresentando feixes nervosos de diferentes espessuras que formaram malha difusa sobre toda a extensão da face posterior da musculatura traqueal;

4. Em todos os grupos ( $N, D$ e R), os gânglios e neurônios apresentaram morfologia variada, sem que fosse possível, determinar os grupos por uma característica exclusiva, devido à pequena quantidade de atributos particulares correlacionados a cada grupo;

5. Quando expressada, a intensa imunorreatividade à SP foi detectada apenas em neurônios pequenos de todos os grupos ( $N$, D e R), o mesmo aplicando-se ao VIP nos grupos $\mathrm{N}$ e R. Relativamente a essa imunorreatividade, a mesma apresentou-se fraca nos animais do grupo D.

6. Não houve diferenças entre os grupos quando se comparou o número total de neurônios e gânglios reativos tanto à NADH-d quanto à NADPHd; 
7. A maior média da área do perfil dos corpos neuronais e gânglios reativos à $\mathrm{NADH}-\mathrm{d}$ foi observada nos animais do grupo $\mathrm{N}$, demonstrando que a renutrição, pelo período proposto, não foi capaz de recuperar os valores de normalidade quanto a esses parâmetros;

8. Relativamente aos neurônios nitrérgicos (NADPH-d), também os animais do grupo $\mathrm{N}$ apresentaram a maior média da área do perfil dos corpos neuronais; quanto à área dos gânglios, não foram verificadas diferenças estatisticamente significantes entre os grupos (N, D e R);

9. A desnutrição não foi capaz de alterar a distribuição do número de neurônios ou gânglios reativos à NADH-d e à NADPH-d do plexo traqueal de nenhum dos grupos estudados (N, D e R) em nenhuma das partes da traquéia. Entretanto, a área média do perfil dos neurônios reativos à NADH-d e à NADPH-d se mostrou significantemente maior na metade torácia da traquéia dos animais do grupo $\mathrm{N}$, e que a renutrição, pelo período proposto, não foi capaz de promover o desenvolvimento dos corpos neuronais do plexo para atingir os valores de normalidade;

10.A área média do perfil dos gânglios reativos à NADH-d dos animais do grupo $\mathrm{N}$ foi maior que a dos grupos $\mathrm{D}$ e $\mathrm{R}$, na metade torácica da traquéia, sendo que entre estes últimos não houve diferença. Por sua vez, a área média do perfil dos gânglios reativos à NADPH-d não demonstrou diferença entre nenhum dos grupos na metade torácica da traquéia;

11. De um modo geral, independente do grupo estudado e da técnica histoquímica utilizada, a metade torácica da traquéia possuía a maior população de neurônios e gânglios, e que estes, praticamente para todas as comparações, eram maiores, quando comparados com aqueles da metade cervical; 
12. Os dados obtidos pela MEV comprovaram a distribuição da malha nervosa sobre a musculatura e a estreita relação entre os feixes nervosos e os corpos neuronais, ainda a morfologia irregular dos gânglios e neurônios do plexo traqueal, anteriormente avaliada por meio das técnicas histoquímicas.

Em linhas gerais a desnutrição protéica provocou atraso no desenvolvimento do animal como um todo, inclusive nos constituintes do plexo traqueal, e que, em somente poucos casos, a recuperação nutricional foi responsável, por retornar os valores de normalidade, apresentados pelos animais nutridos. 


\section{REFERÊNCIAS}

ADLARD, B. P.; DOBBING, J. Vulnerability of developing brain. 3. Development of four enzymes in the brains of normal and undernourished rats. Brain Res., v. 28, p. 97-107, 1971.

AKAMATSU, F. E.; DE-SOUZA, R. R.; LIBERTI, E. A. Fall in the number of intracardiac neurons in aging rats. Mechanisms of Ageing and Development, v. 109 , p. 153-161, 1999.

AKAMATSU, F. E. Características Estruturais, Ultra-estruturais e Morfométricas do Plexo Subepicárdico de Ratos Submetidos à Desnutrição Protéica Pré e Pós-natal e a Renutrição Pós-natal. 2006. 157 f. Tese (Doutorado em Ciências Morfofuncionais) - Instituto de Ciências Biomédicas, Universidade de São Paulo, São Paulo, 2006.

ALBRECHT MAY, C. Comparative Anatomy of the Optic Nerve Head and Inner Retina in Non-Primate Animal Models Used for Glaucoma Research. The Open Ophthalmology Journal, v. 2, p. 94-101, 2008.

ALBUQUERQUE JUNIOR, R. F.; BEL, E. A. D.; BRENTEGANI, L. G.; OLIVEIRA, M. T. M.; ISSA, J. P. M. Trigeminal nitric oxide synthase expression correlates with new bone formation during distraction osteogenesis. Calcif. Tissue Int., v. 82, p. 309-315, 2008.

ALMEIDA, C. A. N.; RICCO, R. G. Avaliação do estado nutricional com ênfase à antropometria. Pediatria (São Paulo), v. 20, p. 385-398, 1998.

AMARAL, J.; LEITE, A. J. M.; CUNHA, A. J. L. A.; VICTORA, C. G. Impact of $I \mathrm{MCl}$ health worker training on routinely collected child health indicators in Northeast Brazil. Health Policy and Planning, v. 20, p. 42-48, 2005. Supplement 1.

ANDREEVA, N. A.; SHUMATOVA, T. A.; MOTAVKIN, P. A. Nitrergic neurons in respiratory organs. Bull. Exp. Biol. Med., v. 129, p. 222-224, 2000.

\footnotetext{
*De acordo com: ASSOCIAÇÃO BRASILEIRA DE NORMAS TÉCNICAS. NBR 6023: Informação e documentação: referências: elaboração. Rio de Janeiro, 2002.
} 
ARORA, N. S.; ROCHESTER, D. F. Respiratory muscle strength and maximal voluntary ventilation in undernourished patients. Am. Rev. Respir. Dis., v. 126, p. 5-8, 1982.

BAKER, D. G.; MCDONALD, D. M.; BASBAUM, C. B.; MITCHELL, R. A. The architecture of nerves and ganglia of the ferret trachea as revealed by acetylcholinesterase histochemistry. Journal of Comparative Neurology, v. 246, p. 513-526, 1986.

BALUK, P.; FUJIWARA, T.; MATSUDA, S. The fine structure of the ganglia of the guinea-pig trachea. Cell Tissue Res., v. 239, p. 51-60, 1985.

BALUK, P.; GABELLA, G. Fine structure of the autonomic ganglia of the mouse pulmonary vein. Journal of Neurocytology, v. 16, p. 169-184, 1987.

BALUK, P.; GABELLA, G. Tracheal parasympathetic neurons of rat, mouse and guinea-pig: partial expression of noradrenergic phenotype and lack of innervation from noradrenergic nerve fibers. Neuroscience Letters, v. 102, p. 191-196, 1989a.

BALUK, P.; GABELLA, G. Innervation of the Guinea Pig Trachea: A Quantitative Morphological Study of Intrinsic Neurons and Extrinsic Nerves. Journal of Comparative Neurology, v. 285, p. 117-132, 1989b.

BAPTISTA, J. S. Repercussões morfológicas no timo de ratos jovens submetidos à desnutrição protéica e à renutrição precocemente corrigida. 2008. 107 f. Dissertação (Mestrado em Ciências) - Instituto de Ciências Biomédicas, Universidade de São Paulo, São Paulo, 2008.

BARNES, P. J. Asthma as an axon reflex. Lancet, v. 1, p. 242-245, 1986.

BARRETO, I. C. H. C.; GRISI, S. J. F. E. Morbidade referida e seus condicionantes em crianças de 5 a 9 anos em Sobral, CE, Brasil. Rev. Bras. Epidemiol., v. 13, p. 35-48, 2010.

BELAI, A.; SCHMIDT, H. H.; HOYLE, C. H.; HASSALL, C. J.; SAFFREY, M. J.; MOSS, J.; FÖRSTERMANN, U.; MURAD, F.; BURNSTOCK, G. Colocalization of nitric oxide synthase and NADPH-diaphorase in the myenteric plexus of the rat gut. Neurosci. Lett., v. 143, p. 60-64, 1992. 
BOYER, L.; SIDPRA, D.; JEVON, G.; BUCHAN, A. M.; JACOBSON, K. Differential responses of VIPergic and nitrergic neurons in paediatric patients with Crohn's disease. Auton. Neurosci., v. 134, p. 106-114, 2007.

BRANDÃO, M. C. S. Análise morfoquantitativa do plexo mientérico do intestino delgado de ratos jovens submetidos à desnutrição protéica pré e pós-natal. 1998. 135 f. Dissertação (Mestrado em Anatomia Funcional) Instituto de Ciências Biomédicas, Universidade de São Paulo, São Paulo, 1998.

BRANDÃO, M. C. S.; DE ANGELIS, R. C.; DE-SOUZA, R. R.; FRÓES, L. B.; LIBERTI, E. A. Effects of pre- and postnatal protein energy deprivation on the myenteric plexus of the small intestine: a morphometric study in weanling rats. Nutrition Research, v. 23, p. 215-223, 2003.

BULT, H.; BOECKXSTAENS, G. E.; PELCKMANS, P. A.; JORDAENS, F. H.; VAN MAERCKE, Y. M.; HERMAN, A. G. Nitric oxide as an inhibitory nonadrenergic non-cholinergic neurotransmitter. Nature, v. 345, p. 346-347, 1990.

CAMERON, A. R.; COBURN, R. F. Eletrical and anatomic characteristic of cells of ferret paratracheal ganglion. Am. J. Physiol., v. 246, p. C450-C458, 1984.

CANNING, B. J. Neurokinin3 receptor regulation of the airways. Vascul. Pharmacol., v. 45, p. 227-234, 2006.

CANNING, B. J.; FISCHER, A. Neural regulation of airway smooth muscle tone. Respir. Physiol., v. 125, p. 113-127, 2001.

CANNING, B. J.; REYNOLDS, S. M.; ANUKWU, L. U.; KAJEKAR, R.; MYERS, A. C. Endogenous neurokinins facilitate synaptic transmission in guinea pig airway parasympathetic ganglia. Am. J. Physiol. Regul. Integr. Comp. Physiol., v. 283, p. 320-330, 2002.

CASTELUCCI, P. Análise morfoquantitativa do plexo mientérico do intestino grosso de ratos submetidos à desnutrição protéica pré e pósnatal e à renutrição pós-natal. 1999. 125f. Tese (Doutorado em Ciências Biológicas) - Instituto de Ciências Biomédicas, Universidade de São Paulo, São Paulo, 1999. 
CASTELUCCI, P.; DE SOUZA, R. R.; ANGELIS, R. C.; FURNES, J. B.; LIBERTI, E. A. Effects of pré- and postnatal protein deprivation and postnatal refeeding on myenteric neurons of the rat large intestine: a quantitative morphological study. Cell Tissue Res., v. 310, p. 1-7, 2002a.

CASTELUCCI, P.; ROBBINS, H. L.; FURNESS, J. B. P2X2 purine receptor immunoreactivity of intraganglionic laminar endings in the mouse gastrointestinal tract. Cell Tissue Res., v. 312, p. 167-174, 2002b.

CHANDRA, R. K. Protein-energy malnutrition and immunological responses. J. Nutr., v. 122, p. 597-600, 1992.

CHEN, F.; CAO, Y.; QIAN, J.; SHAO, F.; NEIDERREITHER, K.; CARDOSO, W. $\mathrm{V}$. A retinoic acid-dependent network in the foregut controls formation of the mouse lung primordium. J. Clin. Invest., v. 120, p. 2040-2048, 2010.

CHIANG, C. H. Distribution of the ganglion neurons in the trachea of the rat. Kaibogaku Zasshi, v. 68, p. 607-616, 1993.

CHIANG, C. H.; GABELLA, G. Quantitative study of the ganglion neurons of the mouse trachea. Cell Tissue Res., v. 246, p. 243-252, 1986.

COBURN, R. F. Peripheral airway ganglia. Annu. Rev. Physiol., v. 49, p. 573582, 1987.

COLLINS, S.; DENT, N.; BINNS, P.; BAHWERE, P.; SADLER, K.; HALLAN, A. Management of severe acute malnutrition in children. Lancet, v. 368, p. 19922000, 2006.

COMAN, D.; YAPLITO-LEE, J.; BONEH, A. New indications and controversies in arginine therapy. Clin. Nutr., v. 27, p. 489-496, 2008.

CONBOY, V. B.; SANTER, R. M.; SWIFT, G. L. Effect of prenatal undernutrition on prevertebral sympathetic neurons in the rat: a morphological and flourescence histochemical study. J. Anat., v. 154, p. 47-53, 1987.

CORDERO, M. E.; TREJO, M.; GARCIA, E.; BARROS, T.; ROJAS, A. M.; COLOMBO, M. Dendritic development in the neocortex of adult rats following a maintained prenatal and/or early postnatal life undernutrition. Early Hum. Dev., v. 14 , p. 245-258, 1986. 
CORNBLATH, D. R.; BROWN, M. J. Influence of malnutrition on developing rat peripheral nerves. Exp. Neurol., v. 99, p. 403-411, 1988.

CSERNI, T.; O' DONNEL, A.; PARAN, S.; PURI, P. Correlation of enteric NADPH-d positive cell counts with the duration of incubation period in NADPH-d histochemistry. Pathol. Oncol. Res., v. 15, p. 103-107, 2009.

CULLEY, W. J.; LINEBERGER, R. O. Effect of undernutrition on the size and composition of the rat brain. J. Nutr., v. 96, p. 375-381, 1968.

DAMACENO, R. J. P.; MARTINS, P. A.; DEVINCENZI, M. U. Estado nutricional de crianças atendidas na rede pública de saúde do município de Santos. Rev. Paul. Pedriatr., v. 27, p. 139-147, 2009.

DE ALMEIDA, C. A. N.; RICCO, R. G.; NOGUEIRA, M. P. C.; CIAMPO, L. A. D.; MUCILLO, G. Comparison of four anthropometric methods of nutritional assessment and evaluation of the agreement between two reference populations. Journal of Tropical Pediatrics, v. 45, p. 345-350, 1999.

DE SOUZA, R. R.; GAMA, E. F.; DE CARVALHO, C. A.; LIBERTI, E. A. Quantitative study and architecture of nerves and ganglia of the rat heart. Acta Anat., v. 156, p. 53-60, 1996.

DE SOUZA, R. R.; MORATELLI, H. B.; BORGES, N.; LIBERTI, E. A. Ageinduced nerve cell loss in the myenteric plexus of the small intestine in man. Gerontology, v. 39, p. 183-188, 1993.

DEUCHARS, S. A.; MORRISON, S. F.; MICHAEL, P. G. Medullary-evoked EPSPs in neonatal rat sympathetic preganglionic neurones in vitro. Journal of Physiology, v. 487, p. 453-463, 1995.

DEY, R. D.; SATTERFIELD, B.; ALTEMUS, J. B. Innervation of tracheal epithelium and smooth muscle by neurons in airway ganglia. Anat. Rec., $v$. 254, p. 166-172, 1999.

DIAS, C. M.; PÁSSARO, C. P.; CAGIDO, V. R.; EINICKER-LAMAS, M.; LOWE, J.; NEGRI, E. M.; CAPELOZZI, V. L.; ZIN, W. A.; ROCCO, P. R. M. Effects of undernutrition on respiratory mechanics and lung parenchyma remodeling. $\mathbf{J}$. Appl. Physiol., v. 97, p. 1888-1896, 2004. 
DOMENEGHINI, C.; RADAELLI, G.; ARRIGHI, S.; BOSI, G.; DOLERA, M. Cholinergic, nitrergic and peptidergic (Substance $P$ and CGRP-utilizing) innervation of the horse intestine. A histochemical and immunohistochemical study. Histol. Histopathol., v. 19, p. 357-370, 2004.

DUDZINSKA, B.; WOZNIAK, W. Intramural plexuses in the trachea and bronchi of human fetuses. Folia Morphol., v. 2, p. 159-166, 1977.

EAKER, E. Y.; SALLUSTIO, J. E. The distribution of a novel intermediate filament protein defines subpopulation of myenteric neurons in rat intestine. Gastroenterology, v. 107, p. 666-674, 1994.

ELFTMAN, A. G. The afferent and parasympathetic innervation of the lungs and trachea of the dog. Amer. J. Anat., v. 72, p. 1-28, 1943.

ESCUDER, M. M. H.; SILVA, N. N.; PEREIRA, J. C. C.; PUCCINI, R. F.; HERRMAN, A. A. Avaliação da morbidade em comunidade infantil. Rev. Saúde Pública, v. 33, p. 349-357, 1999.

EUSTÁQUIO-SILVA, R. Avaliação estrutural e quantitativa dos efeitos do envelhecimento sobre o gânglio trigeminal de ratos Wistar. 2010. $103 \mathrm{f}$. Dissertação (Mestrado em Ciências) - Faculdade de Medicina Veterinária e Zootecnia, Universidade de São Paulo, São Paulo, 2010.

EZZELL, L.; JENSEN, G. L. Malnutrition in chronic obstructive pulmonar disease. Am. J. Clin. Nutr., v. 72, p. 1415-1416, 2000.

FABRICIUS, M.; RUBIN, I.; BUNDGAARD, M.; LAURITZEN, M. NOS activity in brain and endothelium: relation to hypercapnic rise of cerebral blood flow in rats. Am. J. Physiol., v. 271, p. 2035-2044, 1996.

FISH, I.; WINICK, M. Effect of malnutrition on regional growth of the developing rat brain. Exp. Neurol., v. 25, p. 534-540, 1969.

FISHER, A. W. F. The intrinsic innervation of the trachea. J. Anat., v. 98, p. 117-124, 1964.

FONTES, R. B. V.; FROES, L. B.; OMAR, E. D.; LIBERTI, E. A. The myenteric plexus of the rat colon after fecal stream diversion: a morpho-quantitative study. Autonomic Neuroscience: Basic and Clinical, v. 114, p. 39-46, 2004. 
FURLAN, M. M.; DE MIRANDA NETO, M. H.; SANT'ANA, D. M.; MOLINARI, S. L. Number and size of myenteric neurons of the duodenum of adult rats with acute diabetes. Arq. Neuropsiquiatr., v. 57, p. 740-745, 1999.

FURLANI, V. C. G.; HABACUQUE, T. S.; LIBERTI, E. A.; DE SOUZA, R. R. Morphological and quantitative study of ganglioned plexus of Calomys callosus trachea. Autonomic Neuroscience, v. 144, p. 30-35, 2008.

FURNESS, J. B.; LI, Z. S.; YOUNG, H. M.; FÖRSTERMANN, U. Nitric oxide synthase in the enteric nervous system of the guinea-pig: a quantitative description. Cell Tissue Res., v. 277, p. 139-149, 1994.

GABELLA, G. Detection of nerve cells by histochemical technique. Experientia, v. 25, p. 218-219, 1969.

GABELLA, G. Structure of muscles and nerves in the gastrointestinal tract. In: JONHSON, L. R., Physiology of the gastrointestinal tract. 3rd ed. New York: Raven Press, 1994. v. 1, p. 751-793.

GABELLA, $G$. The number of neurons in the small intestine of mice, guinea-pigs and sheep. Neuroscience, v. 22, p. 737-752, 1987.

GABELLA, G. The Rat Nervous System. 3rd ed. Amsterdam: Elsevier, 2004.

GAETANI, S.; MENGHERI, E.; ROSSI, A.; SPADONI, M. A.; TOSCHI, G. Long term protein deficiency in adult rats. Effects on different proteins of a symphatetic ganglion. Neurochemical Res., v. 2, p. 439-448, 1977.

GHOSH, S.; VAID, K.; MOHAN, M.; MAHESHWARI, M. C. Effect of degree and duration of protein energy malnutrition on peripheral nerves in children. Journal of Neurology, Neurosurgery, and Psychiatry, v. 42, p. 760-763, 1979.

GOMES, O. A.; CASTELUCCI, P.; De VASCONCELOS FONTES, R. B.; LIBERTI, E. A. Effects of pré- and postnatal protein deprivation and postnatal refeeding on myenteric neurons of the small intestine: a quantitative morphological study. Auton. Neurosc., v. 126-127, p. 277-284, 2006.

GOSENS, R.; ZAAGSMA, J.; GROOTTE BROMHAAR, M.; NELEMANS, A.; MEURS, $H$. Acetylcholine: a novel regulator of airway smooth muscle remodelling? Eur. J. Pharmacol., v. 500, p. 193-201, 2004. 
GRAY, H. Gray Anatomia. 29. ed. Rio de Janeiro: Guanabara Koogan, 1977.

GREGGIO, F. M. Avaliação histoquímica e morfométrica dos efeitos da desnutrição pré e pós-natal no plexo mientérico do esôfago de ratos. 2001. 55 f. Dissertação (Mestrado em Anatomia Funcional) - Instituto de Ciências Biomédicas, Universidade de São Paulo, São Paulo, 2001.

GREGGIO, F. M.; DE VASCONCELOS FONTES, R. B.; MAIFRINO, L. B. M.; CASTELUCCI, P.; SOUZA, R. R.; LIBERTI, E. A. Effects of perinatal protein deprivation and recovery on esophageal myenteric plexus. World J. gastroenterol., v. 16, p. 563-570, 2010.

GROSS, N. J.; SKORODIN, M. S. Role of the parasympathetic system in airway obstruction due to emphysema. N. Engl. J. Med., v. 311, p. 421-425, 1984.

GROZDANOVIC, Z.; BAUMGARTEN, H. G.; BRÜNING, G. Histochemistry of $\mathrm{NADPH}$-diaphorase, a marker for neuronal nitric oxide synthase, in the peripheral autonomic nervous system of the mouse. Neuroscience, v. 48, p. 225-235, 1992.

GUEMBE, L.; VILLARO, A. C. Histochemical demonstration of neuronal nitric oxide synthase during development of mouse respiratory tract. Am. J. Respir. Cell Mol. Biol., v. 20, p. 342-351, 1999.

HARKEMA, J. R.; MAUDERLY, J. L.; GREGORY, R. E.; PICKRELL, J. A. A comparison of starvation and elastase models of emphysema in the rat. Am. Rev. Respir. Dis., v. 129, p. 584-591, 1984.

HARRIS, S. J.; WILCE, P.; BEDI, K. S. Exposure of rats to a high but not low dose of ethanol during early postnatal life increases the rate of loss of optic nerve axons and decreases the rate of myelination. J. Anat., v. 197, p. 477$485,2000$.

HASANEEN, N. A.; FODA, H. D.; SAID, S. I. Nitric oxide and vasoactive intestinal peptide as co-transmitters of airway smooth-muscle relaxation: analysis in neuronal nitric oxide synthase knockout mice. Chest, v. 124, p. 1067-1072, 2003.

HASSALL, C. J.; SAFFREY, M. J.; BURNSTOCK, G. Expression of NADPHdiaphorase activity by guinea-pig paratracheal neurones. Neuroreport, v. $4, p$ 49-52, 1993. 
HEDLEY-WHITE, E. T.; MEUSER, C. S. The effect of undernutrition on myelination of rat sciatic nerve. Lab. Invest., v. 24, p. 156-161, 1971.

HEINICKE, E. A.; KIERNAN, J. A.; WIJSMAN, J. Specific, selective, and complete staining of neurons of the myenteric plexus, using cuprolinic blue. J. Neurosci. Methods, v. 21, p. 45-54, 1987.

HERNÁNDEZ, C. J.; ORTíZ, T.; FOSTER, C. R. K.; TYAGI, M.; LUGO, N.; ALBRECHT, R.; CHINAPEN, S. Substance P and acetylcholine are co-localized in the pathway mediating mucociliary activity in Rana pipiens. Comp. Biochem. Physiol. Biochem. Mol. Biol., v. 146, p. 477-481, 2007.

HONJIN, R. On the ganglia and nerves of the lower respiratory tract of the mouse. J. Morph., v. 95, p. 263-287, 1954.

HOSTL, M. C.; POWLEY, T. C. Cuprolinic blue (quinolinic phthalocyanine) counterstaining of enteric neurons for peroxidase immunocytochemistry. Journal of Neuroscience Methods, v. 62, p. 121-127, 1995.

INSTITUTO BRASILEIRO DE GEOGRAFIA E ESTATÍSTICA. Pesquisa de orçamentos familiares: 2008-2009: antropometria e estado nutricional de crianças, adolescentes e adultos no Brasil. Rio de Janeiro: IBGE, 2010. Disponível em: $<$ http://www.ibge.gov.br/home/presidencia/noticias/noticia_visualiza.php?id_noti cia=1699\&id_pagina=1>. Acesso em: 6 dez. 2010

JUNQUEIRA, L. C.; CARNEIRO, J. Histologia básica. 9. ed. Rio de Janeiro: Guanabara Koogan, 1999.

KALENGA, M.; EECKOUT, Y. Effects of protein deprivation from the neonatal period on lung collagen and elastin in the rat. Pediatr. Res., v. 26, p. 125-127, 1989.

KARAOSMANOGLU, T.; AYGUN, B.; WADE, P. R.; GERSHON, M. D. Regional differences in the number of neurons in the myenteric plexus of the guinea pig small intestine and colon: an evaluation of markers used to count neurons. Anat. Rec., v. 244, p. 470-480, 1996. 
KARLSSON, J. Excitatory nonadrenergic, noncholinergic innervation of airways smooth muscle: Role of peptides. In: RAEBURN, D.; GIEMBYEZ, M. A. (Ed.) Airways smooth muscle: structure innervation and neurotransmitter Verlag. Basel: Birkhauser, 1994. p. 103-142.

KARNOWSKY, M. J.; ROOTS, L. A. "Direct-Coloring" Thiocoline method for cholinesterase. J. Histochem. Cytochem., v. 12, p. 219-221, 1964.

KERÄNEN, U.; VANHATALO, S.; KIVILUOTO, T.; KIVILAAKSO, E.; SOINILA, S. Co-localization of NADPH diaphorase reactivity and vasoactive intestinal polypeptide in human colon. J. Auton. Nerv. Syst., v. 54, p. 177-183, 1995.

KERR, J. S.; RILEY, D. T.; LANZA-JACOBY, S.; BERG, R. A.; SPILKER, H. C.; YU, S. Y.; EDELMAN, N. H. Nutritional emphysema in the rat: influence of protein depletion and impaired lung growth. Am. Rev. Respir. Dis., v. 131, p. 644-650, 1985.

KESLER, B. S.; MAZZONE, S. B.; CANNING, B. J. Nitric oxide-dependent modulation of smooth-muscle tone by airway parasympathetic nerves. Am. J. Respir. Crit. Care Med., v. 165, p. 481-488, 2002.

KOHN, A. Z.; HOXHA, Z.; BALAN, K. V.; MARTIN, R. J.; HAXHIU, M. A.; WILSON, C. G.; MAYER, C. A.; PRABHA K. Developmental changes in brainstem neurons regulating lower airway caliber. Pediatr. Res., v. 65, p. 509513,2009

KONDO, F.; KONDO, Y.; MAKINO, H.; OGAWA, N. Delayed neuronal death in hippocampal CA1 pyramidal neurons after forebrain ischemia in hyperglycemic gerbils: amelioration by indomethacin. Brain Res., v. 853, p. 93-98, 2000.

KRINKE, G. J. The laboratory rat. London: Academic Press, 2000.

KRISHNAN, R. V.; PAL, G. P.; BORADKAR, R. V. Size plasticity of intact motoneurons as reaction to partial denervation of muscle. Int. J. Neurosci., v. 17, p. 43-49, 1982.

KUDER, T.; SZCZURKOWSKI, A.; KUCHINKA, J.; NOWAK, E. The AChEpositive ganglia in the trachea and bronchi of the cat. Folia Morphol. (Warsz), v. 62, p. 99-106, 2003. 
KUMMER, W.; LIPS, K. S.; PFEIL, U. The epithelial cholinergic system of the airways. Histochem. Cell Biol., v. 130, p. 219-234, 2008.

KUO, H.; GRANT, S.; MUTH, N.; HENGEMIHLE, J.; INGRAM, D. K. The correlation between neurons counts and optical density of NADPH-diaphorase histochemistry in the rat striatum: a quantitative study. Brain Research, v. 660, p. 57-65, 1994.

KUSINDARTA, D. L.; ATOJI, Y.; YAMAMOTO, Y. Nerves plexuses in the trachea and extrapulmonary bronchi of the rat. Arch. Histol. Cytol., v. 67, p. 41-55, 2004.

LECHNER, A. J.; WINSTON, D. C.; BAUMAN, J. E. Lung mechanics, cellularity, and surfactant after prenatal starvation in guinea pigs. J. Appl. Physiol., v. 60, p. 1610-1614, 1986.

LIBERTI, E. A.; FONTES, R. B. V.; FUGGI, V. M.; MAIFRINO, L. B. M.; SOUZA, R. R. Effects of combined pre- and post-natal protein deprivation on the myenteric plexus of the esophagus of weanling rats: A histochemical, quantitative and ultrastructural study. World J. Gastroenterol., v. 13, p. 35983604, 2007.

MABE, A. M.; HOOVER, D. B. Structural and functional cardiac cholinergic deficits in adult neurturin knockout mice. Cardiovascular Research, v. 82, p. 93-99, 2009.

MACHADO, A. Sistema nervoso autônomo: aspectos gerais. In: Neuroanatomia Funcional. 2. ed. São Paulo: Atheneu, 2002. Cap. 13. p. 129137.

MAIFRINO, L. B.; LIBERTI, E. A.; WATANABE, I.; DE SOUZA, R.R. Morphometry and acetylcholinesterase activity of the myenteric neurons of the mouse colon in the chronic phase of experimental Trypanosoma cruzi infection. Am. J. Trop. Med. Hyg., v. 60, p. 721-725, 1999.

MAIFRINO, L. B. M.; LIBERTI, E. A.; CASTELUCCI, P.; SOUZA, R. R. NADPHDiaphorase cardiac neurons in the atria of mice. A Morphoquantitative Study. B. M. C. Neuroscience (Online), Londres, v. 7, p. 1-14, 2006. 
MATECKI, S.; PY, G.; LAMBERT, K.; PEYREIGNE, C.; MERCIER, J.; PREFAUT, C.; RAMONATXO, M. Effect of prolonged undernutrition on rat diaphragm mitochondrial respiration. Am. J. Respir. Cell Mol. Biol., v. 26, p. 239-245, 2002.

MATHESON, D. F. Some quantitative aspects of myelination of the optic nerve in rat. Brain Res., v. 24, p. 257-269, 1970.

MANDARIM-DE-LACERDA, C. A. Métodos quantitativos em morfologia. Rio de Janeiro: Eduerj, 1995.

MASSARI, V. J.; HAXHIU, M. A. Substance P afferent terminals innervate vagal preganglionic neurons projecting to the trachea of the ferret. Auton. Neurosci., v. 96, p. 103-12, 2002.

MIRANDA-NETO, M. H.; FURLAN, M. M.; SANT'ANA, D. D.; MOLINARI, S. L.; SOUZA, J. A. Evaluation of the areas of neuronal cell bodies and nuclei in the myenteric plexus of the duodenum of adult rats. Arq. Neuropsiquiatr., v. 58, p. 246-251, 2000.

MISAWA, R. Estudo morfoquantitativo de neurônios entéricos do íleo imonurreativos ao receptor P2X2, a calbindina, a calretinina, a colina acetiltransferase e ao óxido nítrico de animais submetidos à desnutrição e a renutrição protéica. 2007. 100 f. Dissertação (Mestrado em Ciências) Instituto de Ciências Biomédicas, Universidade de São Paulo, São Paulo, 2007.

MIZUNO, M. S. Análise morfoquantitativa e do código químico do receptor purinérgico $\mathrm{P}_{2} \mathrm{X}_{2}$ no plexo mioentérico de camundongos obesos (ob/ob) fêmeas e machos. 2010. 150 f. Tese (Doutorado em Ciências Morfofuncionais) - Instituto de Ciências Biomédicas, Universidade de São Paulo, São Paulo, 2010.

MIZUNO, M. S.; POMPEU, E.; CASTELUCCI, P.; LIBERTI, E. A. Age-related changes in urinary bladder intramural neurons. Int. J. Devl. Neuroscience, v. 25, p. 141-148, 2007.

MONCADA, S.; PALMER, R. M.; HIGGS, E. A. Nitric oxide: physiology, pathophysiology, and pharmacology. Pharmacol. Rev., v. 43, p. 109-142, 1991. 
MONTEDONICO, S.; SRI PARAN, T.; PIRKER, M.; ROLLE, U.; PURI, P. Developmental changes in submucosal nitrergic neurons in the porcine distal colon. J. Pediatr. Surg., v. 41, p. 1029-1035, 2006.

MONTEIRO, C. A. A dimensão da pobreza, da fome e da desnutrição no Brasil. Estudos avançados, v. 9, p. 1995-1207, 1995.

MONTEIRO, C. A.; ZUNIGA, H. P. P.; BENÍCIO, M. H. D.; SZARFARC, S. C. Estudo das condições de saúde das crianças do Município de São Paulo, SP (Brasil), 1984-1985. I - Aspectos metodológicos, características sócioeconômicas e ambiente físico. Rev. Saúde Públ., São Paulo, v. 20, p. 435-445, 1986.

MORO, J. M. R. G.; DÍES, J. M.; GONZÁLES, L. P.; GARCÍA, M. J. B.; SIMINIANI, A. S.; RAMOS, P. L. Abnormalities of the respiratory function and control of ventilation in patients with anorexia nervosa. Respiration, v. 704, p. 490-495, 2003.

MURCIANO, D.; RIGAUD, D.; PINGLETON, S.; ARMENGAUD, M. H.; MELCHIOR, J. C.; AUBIER, M. Diaphragmatic function in severely malnourished patients with anorexia nervosa. Am. J. Respir. Crit. Care Med., v. 150, p. 1569-1574, 1994.

NADEEM, A.; PONNOTH, D. S.; ANSARI, H. R.; BATCHELOR, T. P.; DEY, R. D.; LEDENT, C.; MUSTAFA, S. J. A2A Adenosine Receptor Deficiency Leads to Impaired Tracheal Relaxation via NADPH Oxidase Pathway in Allergic Mice. JPET, v. 330, p. 99-108, 2009.

NADEL, J. A.; BARNES, P. J. Autonomic Regulation of the Airways. Ann. Rev. Med., v. 35, p. 451-467, 1984.

NAKAJIMA, K.; TOOYAMA, I.; YASUHARA, O.; AIMI, Y.; KIMURA, H. Immunohistochemical demonstration of choline acetyltransferase of a peripheral type (pChAT) in the enteric nervous system of rats. J. Chem. Neuroanat., v. 18 , p. $31-40,2000$.

NICOLL, A.; BEDI, K. S.; WIGMORE, P. M. The effect of neonatal monocular enucleation on the optic nerves of the rat. J. Anat., v. 174, p. 27-35, 1991.

NÓBREGA, F. J. Desnutrição Intra-Uterina e Pós-Natal. 2. ed. São Paulo: Panamed Editorial, 1986. 
OLDFORS, A. Nerve fibre degeneration of the central and peripheral nervous systems in severe protein deprivation in rats. Acta Neuropathol., v. 54, p. 121127, 1981.

OLIVEIRA, F. Características histoquímicas das fibras musculares do $\mathbf{m}$. Gastrocnêmio de ratos wistar desnutridos submetidos à lesão térmica. 2006. 140 f. Tese (Doutorado em Ciências) - Instituto de Ciências Biomédicas, Universidade de São Paulo, São Paulo, 2006.

OSINSKI, M. A.; BASS, P. Chronic denervation of rat jejunum results in cholinergic supersensitivity due to reduction of cholinesterase activity. $\mathbf{J}$. Pharmacol. Exp. Ther., v. 266, p. 1684-1690, 1993.

PELLETIER, D. L. Potentiating effects of malnutrition on child mortality: Epidemiologic evidence and policy implications. Food Nutr. Bull., v. 16, p. 206213, 1995.

PETERSON, K. E.; CHEN, L. C. Defining undernutrition for public health purposes in the United States. Journal of Nutrition, v. 120, p. 933-942, 1990.

PICHARD, C. From protein-energy malnutrition to refeeding: more basic research is needed. Clin. Nutr., v. 16, p. 1, 1997.

PINGLETON, S. K. Nutrition in chronic critical illness. Clin. Chest Med., v. 22, p. 149-163, 2001.

PRABHA, K. C.; MAYER, C. A.; HAXHIU, M. A. Chemical profile of vagal preganglionic motor cells innervating the airways in ferrets: the absence of noncholinergic neurons. J. Appl. Physiol., v. 97, p. 1508-1517, 2004.

REEVES, P. G.; NIELSEN, F. H.; FAHEY-Jr, G. C. AIN-93 Purified Diets for Laboratory Rodents: Final Report of the American Institute of Nutriton Ad Hoc Writing Committee on the Reformulation of the AIN-76A Rodent Diet. J. Nutr., v. 123, p. 1931-1939, 1993.

RIBEIRO, R. D. New reservoir of Trypanosoma cruzi. Revista Brasileira de Biologia, v. 33, p. 429-537, 1973.

RICHARDSON, J. B.; FERGUSON, C. C. The fine structure of the ganglia in human lung. J. Cell Biol., v. 70, p. 48a, 1976. 
RICHARDSON, J. B. Nerve suplly to the lungs. Am. Rev. Resp. Dis., v. 119, p. 785-802, 1979.

ROLLE, U.; CHERTIN, B.; NEMETH, L.; PURI, P. Demonstration of nitrergic and cholinergic innervation in whole-mount preparations of rabbit, pig, and human upper urinary tract. Pediatr. Surg. Int., v. 18, p. 315-318, 2002.

ROMÁN, V.; KRECSMARIK, M.; BAGYÁNSZKI, M.; FEKETE, É. Evaluation of the total number of myenteric neurons in the developing chicken gut using cuprolinic blue histochemical staining and neurofilament immunocytochemistry. Histochem. Cell Biol., v. 116, p. 241-246, 2001.

ROSS, M. H.; PAWLINA W. Histologia Texto e Atlas. 5 ed. Rio de Janeiro: Guanabara Koogan, 2008.

SAHEBJAMI, H.; VASSALLO, C. L. Effects of starvation and refeeding on lung mechanics and morphometry. Am. Rev. Respir. Dis., v. 119, p. 443-451, 1979.

SANT'ANA, D. M.; MIRANDA-NETO, M. H.; MOLINARI, S. L.; SANT'ANNA, M. A. Neuron number in the myenteric plexus of the ascending colon of rats. $A$ comparative study using two staining techniques. Arq. Neuropsiquiatr., v. 55, p. 460-466, 1997.

SANTER, R. M. Survival of the population of NADPH-diaphorase stained myenteric neurons in the small intestine of aged rats. J. Auton. Nerv. Syst., v. 49, p. 115-121, 1994.

SANTER, R. M.; CONBOY, V. B. Prenatal undernutrition permanently decreases enteric neuron number and sympathetic innervation of Auerbach's plexus in the rat. J. Anat., v. 168, p. 57-62, 1990.

SAWAYA, A. L. Desnutrição: consequências em longo prazo e efeitos da recuperação nutricional. Estud. Av., v. 20, p. 147-158, 2006.

SCHÄFER, K.; FRIEDE, R. L. The onset and rate of myelination in six peripheral and autonomic nerves of the rat. J. Anat., v. 159, p. 181-195, 1988.

SCHERER-SINGLER, V.; VINCENT, S. R.; KIMURA, H.; MCGEER, F. G. Demonstration of a unique population of neurons with NADPH diaphorase histochemistry. Journal of Neuroscience Methods, v. 9, p. 229-234, 1983. 
SEYFERT, C. E. Repercussões morfológicas da lesão térmica corporal nos componentes do plexo mioentérico do jejuno de ratos adultos. 2009. 82 f. Tese (Doutorado em Ciências) - Instituto de Ciências Biomédicas, Universidade de São Paulo, São Paulo, 2009.

SHINGLETON, A. W. The regulation of organ size in Drosophila. Physiology, plasticity, patterning and physical force. Organogenesis, v. 6, p. 76-87, 2010.

SHRADER, R. E.; ZEMAN, F. J. Effect of maternal protein deprivation on morphological and enzimatic development of neonatal rat tissue. J. Nutr., v. 99, p. 401-412, 1969.

SILVA, A. T.; COSTA, F. B. R.; COSTA, J. A.; TEODÓSIO, N. R.; CABRALFILHO, J. E.; GUEDES, R. C. A. Sciatic nerve conduction velocity of malnourished rats fed the "human basic regional diet" of the northeast of Brazil. Braz. J. Med. Biol. Res., v. 20, p. 383-392, 1987.

SOARES, N. T. Um novo referencial antropométrico de crescimento: significados e implicações. Rev. Nutr., v. 16, p. 93-104, 2003.

STERN, J. E. Nitric oxide and homeostatic control: an intercellular signalling molecule contributing to autonomic and neuroendocrine integration? Prog. Biophys. Mol. Biol., v. 84, p. 197-215, 2004.

VAN DER VELDEN, V. H.; HULSMANN, A. R. Autonomic innervation of human airways: structure, function, and pathophysiology in asthma. Neuroimmunomodulation. v. 6, p. 145-159, 1999.

VAN NIEUWSTADT, R. A.; HAJER, R.; BREUKINK, H. J. Autonomic innervation of the airways. Vet. Q., v. 16, p. 110-114, 1994.

VICTORA, C. G.; ARAÚJO, C. L.; DE ONIS, M. Uma nova curva de crescimento para 0 século XXI. 2004. Disponível em: $<$ http://189.28.128.100/nutricao/docs/geral/nova_curva_cresc_sec_xxi.pdf $>$. Acesso em: 6 dez. 2010.

WANG, G. D.; WANG, X. Y.; HU, H. Z.; FANG, X. C.; LIU, S.; GAO, N.; XIA, Y. Platelet-activating factor in the enteric nervous system of the guinea pig small intestine. Am. J. Physiol. Gastrointest. Liver Physiol., v. 291, p. 928-937, 2006. 
WATERLOW, J. C. Classification and definition of protein-calorie malnutrition. British Medical Journal, v. 3, p. 566-569, 1972.

WATVE, M. G.; YAJNIK, C. S. Evolutionary origins of insulin resistance: a behavioral switch hypothesis. BMC Evol. Biol., v. 7, p. 61-73, 2007.

WEI, H.; HUANG, H. M.; LI, T. Y.; QU, P.; LIU, Y. X.; HEN, J. Marginal vitamin A deficiency affects lung maturation in rats from prenatal to adult stage. J. Nutr. Sci. Vitaminol., v. 55, p. 208-214, 2009.

WORLD HEALTH ORGANIZATION. WHO child growth standards. Acta Paediatr., v. 95, p. 1-101, 2006. Supplement.

WU, Z. X.; DEY, R. D. Nerve growth factor-enhanced airway responsiveness involves substance $P$ in ferret intrinsic airway neurons. Am. J. Physiol. Lung Cell Mol. Physiol., v. 291, p. 111-118, 2006.

YAMAMOTO, Y.; OOTSUDA, T.; ATOJI, Y.; SUZUKI, Y. Morphological and quantitative study of the intrinsic nerve plexuses of the canine trachea as revealed by immunohistochemical staining of protein gene product 9.5. Anat. Rec., v. 250, p. 438-447, 1998.

YASHUHARA, O.; MATSUO, A.; BELLIER, J. P.; AIMI, Y. Demonstration of choline acetyltransferase of a peripheral type in the rat heart. Journal of Histochemistry e Cytochemistry, v. 55, p. 287-299, 2007.

ZAAGSMA, J.; VAN AMSTERDAM, R. G.; BROUWER, F.; VAN DER HEIJDEN, P. J.; VAN DER SCHAAR, M. W.; VERWEY, W. M.; VEENSTRA, V. Adrenergic control of airway function. Am. Rev. Respir. Dis., v. 136, p. 45-50, 1987.

ZAR, J. H. Biostatistical analysis. 2. ed. New Jersey: Prentice-Hall, 1984. 